\title{
Belize: 2006 Article IV Consultation-Staff Report; Public Information Notice on the Executive Board Discussion; and Statement by the Executive Director for Belize
}

Under Article IV of the IMF's Articles of Agreement, the IMF holds bilateral discussions with members, usually every year. In the context of the2006 Article IV consultation with Belize, the following documents have been released and are included in this package:

- $\quad$ the staff report for the 2006 Article IV consultation, prepared by a staff team of the IMF, following discussions that ended on August 30, 2006, with the officials of Belize on economic developments and policies. Based on information available at the time of these discussions, the staff report was completed on September 27, 2006. The views expressed in the staff report are those of the staff team and do not necessarily reflect the views of the Executive Board of the IMF.

- a Public Information Notice (PIN) summarizing the views of the Executive Board as expressed during its October 20, 2006 discussion of the staff report that concluded the Article IV consultation.

- $\quad$ a statement by the Executive Director for Belize.

The document listed below has been or will be separately released.

Selected Issues and Statistical Appendix

The policy of publication of staff reports and other documents allows for the deletion of market-sensitive information.

To assist the IMF in evaluating the publication policy, reader comments are invited and may be sent by e-mail to publicationpolicy@imf.org.

$$
\begin{gathered}
\text { Copies of this report are available to the public from } \\
\text { International Monetary Fund • Publication Services } \\
70019^{\text {th }} \text { Street, N.W. • Washington, D.C. 20431 } \\
\text { Telephone: (202) 623-7430 • Telefax: (202) 623-7201 } \\
\text { E-mail: publications@imf.org Internet: http://www.imf.org }
\end{gathered}
$$

Price: $\$ 18.00$ a copy

\section{International Monetary Fund Washington, D.C.}





\title{
INTERNATIONAL MONETARY FUND
}

\section{BELIZE}

\section{Staff Report for the 2006 Article IV Consultation}

\author{
Prepared by the Staff Representatives for the 2006 Consultation with Belize
}

Approved by Christopher Towe and G. Russell Kincaid

October 5, 2006

- Discussions: A staff team comprising Andreas Bauer (Head), Gamal El-Masry, Pelin Berkmen (all WHD), Yingbin Xiao (ICM), and Axel Palmason (PDR) visited Belize during August 17-30, 2006. The mission met with the Prime Minister and his team of economic advisors, the Cabinet's Public Finance Committee, the leader of the opposition, representatives of the private and public sectors, and labor unions. Mr. J. Fried, Executive Director for Belize, and Ms. Y. Alvarez, Advisor to the Executive Director, participated in the concluding meeting.

- Recent developments: Fiscal and monetary policies have been considerably tightened, and nonoil GDP growth has continued to decelerate. The current account deficit is expected to narrow in 2006, reflecting both a moderation in import growth and strong exports of goods and services. However, despite this progress, there remain substantial fiscal and balance of payments financing gaps in 2007 and beyond. In view of this situation, the authorities announced in early August 2006 their intention to approach external commercial creditors for debt service relief.

- Main policy recommendations: Staff recommended additional fiscal and monetary policy tightening in the short term. A return to external and fiscal sustainability will require a sustained additional adjustment effort and closure of remaining financing gaps, including through a cooperative debt restructuring. To bolster the credibility of this adjustment and to reduce vulnerabilities, the authorities should implement supportive structural reforms in the fiscal, monetary, and financial sector areas.

- Exchange system: The Belize dollar has been pegged to the U.S. dollar at BZ\$2=US\$1 since 1976. Belize has accepted the obligations of Article VIII, Sections 2, 3, and 4, and does not maintain exchange restrictions or multiple currency practices. The central bank has not engaged in selective sales or rationing of foreign exchange to the private sector since 2004, and there does not appear to be an unsatisfied foreign exchange demand from commercial banks.

- Statistics: Belize's statistics are adequate for surveillance, and the country has begun participating in the Fund's General Data Disseminations System (GDDS) in September 2006. Progress has been made in increasing the frequency of data diffusion, but further improvements in data quality, coverage, and timeliness are still needed.

- Fund relations: Belize presently has no outstanding use of Fund credit. The authorities are implementing a home-grown adjustment strategy, in close consultation with Fund staff. 


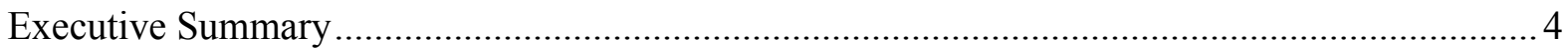

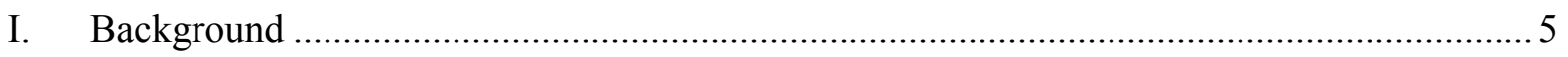

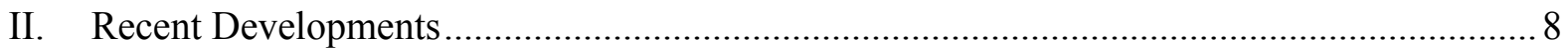

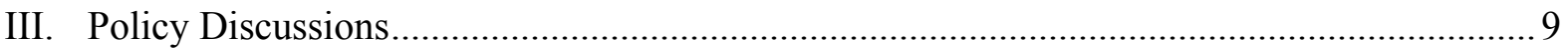

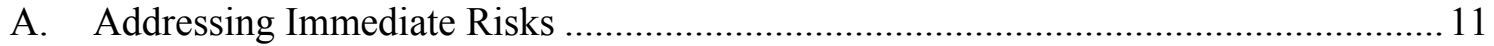

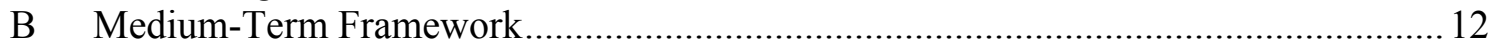

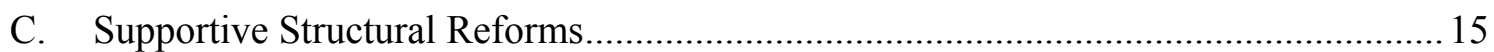

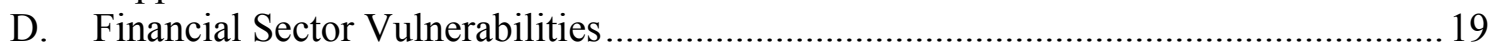

E. Exchange Rate Regime and Competitiveness ....................................................... 20

F. Possible Fund Support ................................................................................. 21

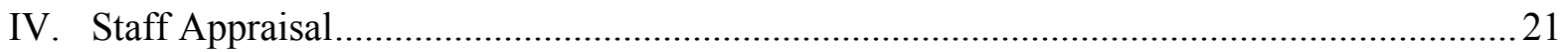

Boxes

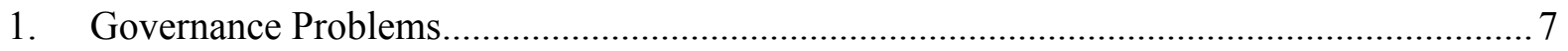

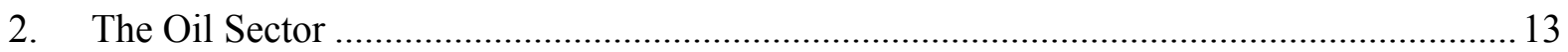

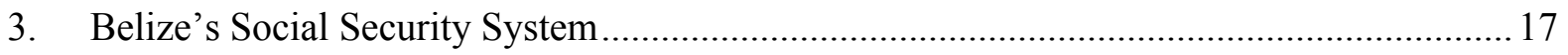

Figures

1. Macroeconomic Performance in a Regional Context, 1999-2005 ...................................24

2. External Competitiveness .............................................................................................. 25

Tables

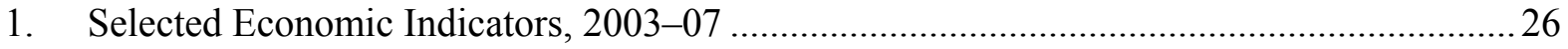

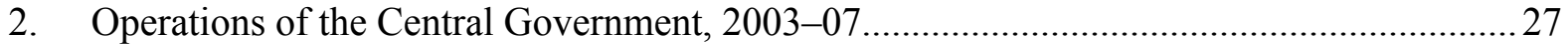

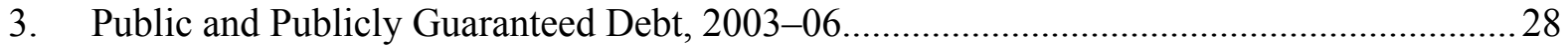

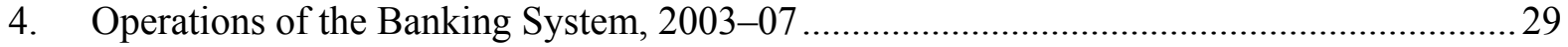

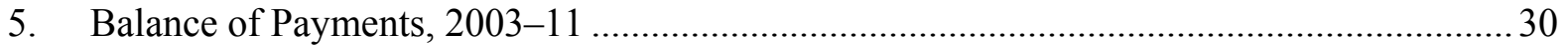

6. Indicators of External Position and Financial Vulnerability, 2003-07 .............................. 31

7. Medium-Term Outlook, 2005-15 (Passive Scenario) ........................................................ 32

8. Public and Publicly Guaranteed Debt Simulations, 2005-15 (Passive Scenario).................. 33

9. Medium-Term Outlook, 2005-15 (Active Scenario) .................................................... 34

10. Public and Publicly Guaranteed Debt Simulations, 2005-15 (Active Scenario) .................. 35 
Appendices

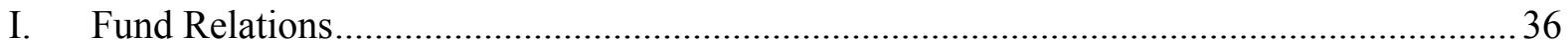

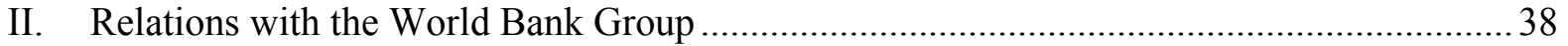

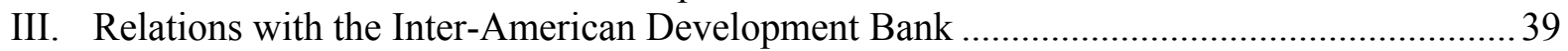

IV. Relations with the Caribbean Development Bank ...................................................... 41

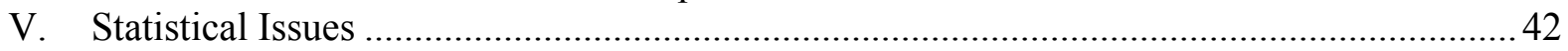

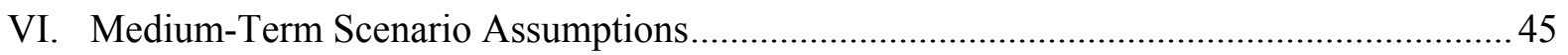

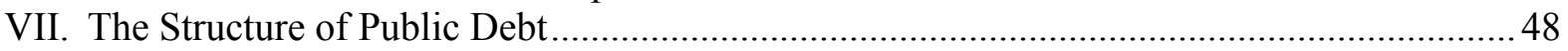

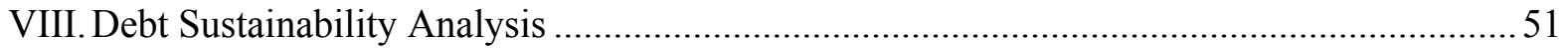

Appendix Tables

VIII. 1. Public and Publicly Guaranteed Debt Sustainability Framework, 2001-11

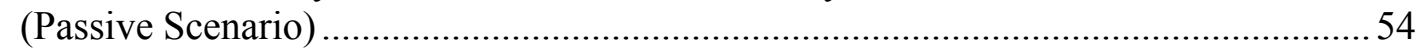

2. Public and Publicly Guaranteed Debt Sustainability Framework, 2001-11

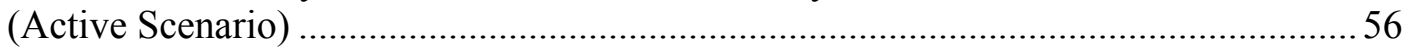

3. Public and Publicly Guaranteed External Debt Sustainability Framework, 2000-11

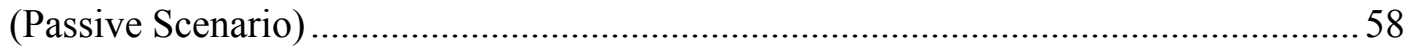

4. External Public and Publicly Guaranteed Debt Sustainability Framework, 2000-11 (Active Scenario)

Appendix Figures

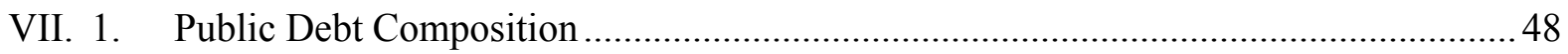

2. Projected Annual Debt Service Payments .......................................................... 50

3. Projected Monthly Debt Service Payments...............................................................50

VIII. 1. Public and Publicly Guaranteed Debt Sustainability Bound Tests (Passive Scenario) ................................................................................................ 55

2. Public and Publicly Guaranteed Debt Sustainability Bound Tests (Active Scenario).. 57

3. Public and Publicly Guaranteed External Debt Sustainability Bound Tests (Passive Scenario) ................................................................................................. 59

4. External Public and Publicly Guaranteed Debt Sustainability Bound Tests (Active Scenario) 


\section{EXECUTIVE SUMMARY}

\section{Recent developments}

- After several years of strong performance, real GDP growth (excluding oil) slowed in 2005 and 2006, while inflation rose moderately, owing mainly to higher fuel prices. The external current account deficit is projected to narrow to $8 \frac{1}{2}$ percent of GDP in 2006, because of slower import growth, and a strong pick up in tourism and export receipts.

- The economic slowdown partly reflects the tightening of fiscal and monetary policies over the past 18 months. Taxes were raised, capital expenditures cut, and monetary conditions tightened. As a result, the primary balance shifted from a small deficit in FY04/05 (April to March) to a surplus of 3 percent of GDP in FY05/06.

- Despite this progress in correcting macroeconomic imbalances, the outlook for 2007 and beyond remains a concern. Scheduled debt service is very high and Belize faces large fiscal and balance of payments financing gaps next year and beyond. Market financing to fill the gaps is unlikely to be forthcoming, and bridging them through domestic adjustment alone does not seem feasible. In these circumstances, the authorities have approached their commercial external creditors for debt service relief. The authorities have remained current on their debt obligations, but in mid-September they announced that payments to two special purpose vehicles, which are part of an issuance of insured bonds, had not been made.

\section{Staff appraisal}

- Macroeconomic policies should be further tightened in 2006 to both mitigate immediate vulnerabilities and demonstrate policy commitment, while a sustainable medium-term framework is formulated and consultations with creditors take place.

- The medium-term framework would need to include a combination of additional fiscal effort, continued monetary restraint, bilateral and multilateral financing, and relief from the envisaged debt operation. The latter is a key element in the government's plan to put public finances on a sustainable basis, and the authorities should seek to reach a cooperative agreement with private creditors.

- To help sustain the required policy effort over time, supportive structural reforms in the fiscal and monetary areas should be implemented.

- Belize's banking system appears generally robust but further steps should be taken to strengthen financial sector supervision.

- Even in the best of circumstances, Belize's economic and financial situation will remain highly vulnerable and therefore leaves little room for slippage in the implementation of the outlined policy framework. 


\section{BACKGROUND}

1. Since independence in 1981, Belize has made important strides, but its present macroeconomic situation poses significant challenges. Over the past 25 years, the country has enjoyed strong growth, as well as price and currency stability. Real per capita income has more than doubled, while social indicators, such as infant mortality and primary school enrollment, have also made

Text Table 1. Social Indicators: Belize and Selected Central American impressive gains. However, living standards still lag in some aspects behind those of neighboring countries, and Belize is now confronted with a heavy public debt burden, a sizeable external current account deficit, and a slowdown in growth (Text Table 1 and Figure 1).

\begin{tabular}{lrrrr}
\multicolumn{4}{c}{ and Caribbean Countries (CAC), 1985-2004 } \\
\cline { 2 - 5 } & \multicolumn{3}{c}{ Belize } & CAC 1/ \\
\hline GDP per capita, PPP (constant 2000 US\$) & 3,055 & 4,911 & 6,201 & 6,937 \\
Life expectancy at birth (years) & 72 & 73 & 72 & 72 \\
Infant mortality rate (per 1,000 live births) & 44 & 36 & 32 & 20 \\
Primary school enrollment (gross, in percent) & $\ldots$ & 112 & 124 & 67 \\
Hospital beds (per 1,000 people) & 3 & 2 & 1 & 1 \\
\hline
\end{tabular}

Sources: World Bank, World Development Indicators, 2005.

1/ Guatemala, Jamaica, Mexico, Panama, and Trinidad and Tobago.

\section{Belize's current macroeconomic difficulties are the result of earlier aggressive} efforts to stimulate economic growth. Beginning in 1999, taxes were lowered, public investment was increased, and cheap credit was provided to the private sector through the state-owned Development Finance Corporation (DFC) and the Social Security Board (SSB). As a result of these measures, the overall deficit of the central government rose from an average of 3 percent of GDP during 1996-98 to almost 10 percent of GDP during 2000-02. At the same time, lax monetary policy led to a sharp build-up of excess liquidity in the banking sector and triggered an acceleration of credit to the private sector.

\section{Growth accelerated sharply in response to the stimulus, but at the expense of a widening external current account} deficit.

- $\quad$ Real GDP increased by 60 percent in cumulative terms between 1998 and 2005, mostly driven by higher domestic demand (Text Table 2). Since 2003, however, growth has slowed, relying increasingly on net exports.

\begin{tabular}{|c|c|c|c|}
\hline & \multicolumn{3}{|c|}{ Cumulative } \\
\hline & $1998-2002$ & $2003-2005$ & $1998-2005$ \\
\hline Gross domestic expenditure & 45.6 & -1.3 & 43.9 \\
\hline Consumption & 32.9 & 1.7 & 35.1 \\
\hline Of which: government final consumption & 3.9 & 1.0 & 5.2 \\
\hline Of which: private final consumption & 29.0 & 0.6 & 29.9 \\
\hline Gross fixed capital formation & 11.6 & -2.8 & 7.9 \\
\hline Changes in inventories incl. discrepancy & 1.2 & -0.2 & 1.0 \\
\hline Net exports & -10.1 & 19.6 & 16.5 \\
\hline Exports of goods and services & 20.6 & 17.6 & 44.5 \\
\hline Imports of goods and services & -31.7 & -0.2 & -32.0 \\
\hline Discrepancy & 1.0 & 2.9 & 5.0 \\
\hline GDP at market prices & 35.6 & 18.4 & 60.4 \\
\hline
\end{tabular}

Source: Central Statistics Office. 
- $\quad$ At the same time, the external current account deficit soared, exceeding 20 percent of GDP a year during 2000-03. These deficits reflected rising resource gaps in both the private and the public sectors (Text Figure 1). More recently, the current account deficit has narrowed somewhat, thanks to a tightening of fiscal and monetary policies.

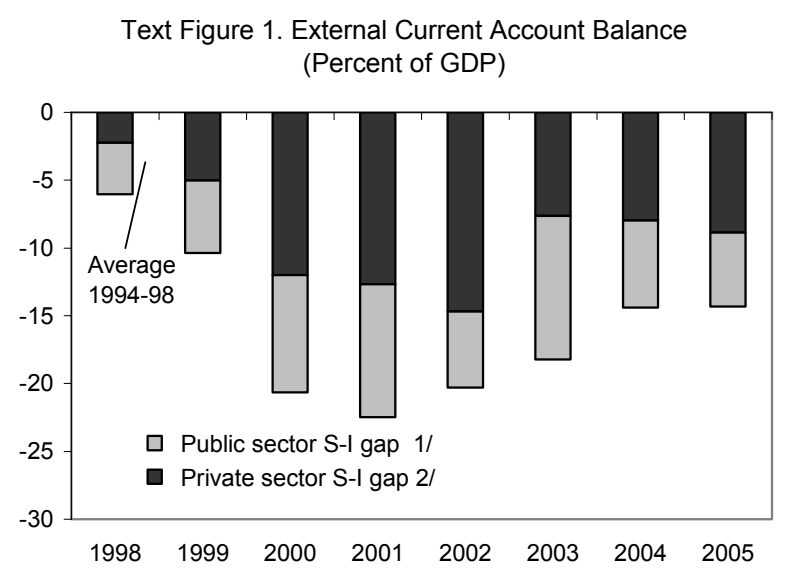

- $\quad$ The large current account deficits were principally financed through a build-up of public debt, which almost tripled from less than US\$400 million in 1998 to US\$1.1 billion in 2005 (Text Figure 2). This increase reflected central government deficits, as well as questionable financial transactions by a number of quasi-fiscal institutions (Box 1). As debt service

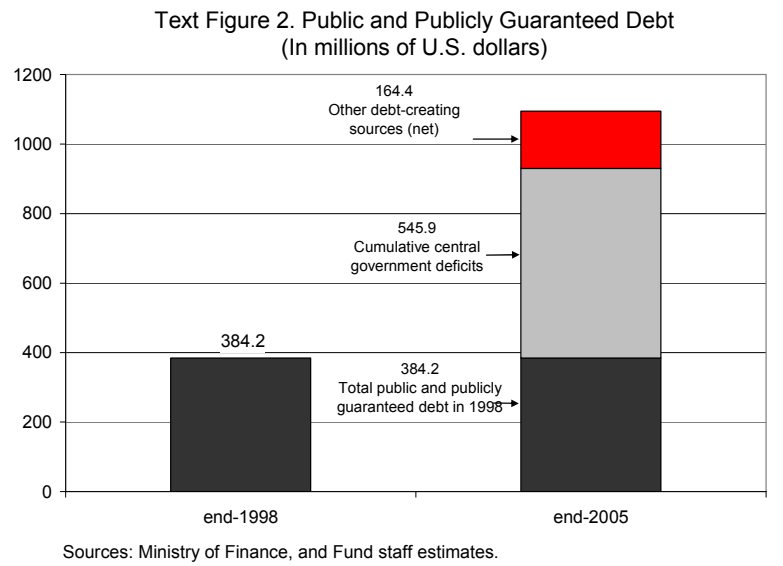
obligations rose and market financing became increasingly difficult to secure, the government resorted to financing from the central bank, whose international reserves fell below one month of import coverage by end-2005.

\section{Concerns about the exchange rate peg and debt sustainability were raised in} earlier Article IV consultations. The government, however, was initially slow to address the rising fiscal and external disequilibria, but the receptiveness to Fund advice increased when Belize's capital market access became impaired. In the second half of 2004, staff was invited to assist the government in developing a home-grown adjustment strategy (Text Table 3). 


\section{Box 1. Governance Problems}

The government of Belize has been affected by several major governance scandals which contributed to the sharp increase in external public debt since 1999. The most egregious cases involved failed privatizations and questionable financial transactions, including:

- Lending by the Development Finance Corporation (DFC): The state-owned DFC increased its assets by about 25 percent of GDP during 1999-2003. However, by 2004 already 40 percent of its assets were either unproductive or nonperforming, reflecting serious conflicts of interest, and poor corporate management and oversight. After mounting losses, the government had to refinance and assume directly an estimated US\$210 million (more than 20 percent of GDP) in external guaranteed loans of the DFC. In late 2004, the authorities announced their intention to wind up the DFC and later replaced its management. Since then, loan operations have ceased and the balance sheet has been reduced by about US\$200 million. The authorities are currently working with the IDB on a strategy for an orderly liquidation of the remaining DFC assets.

- Mortgage securitizations: The DFC and the Social Security Board (SSB) were active in securing loans against future mortgage receivables, raising about US\$150 million in five operations between 1999 and 2002. The most controversial case involved a US\$45 million loan from a U.S. bank, which was raised by the DFC to be in part on-lent via a domestic financial institution to two local companies that had ownership ties with senior DFC management, and which promptly defaulted on their obligations. The government is still exposed to contingent liabilities of about US\$28 million from this operation, while having already assumed external liabilities of about US\$65 million for the other four mortgage securitization operations.

- Telecommunications privatization: After the privatization of the national phone company BTL and the expiration of its monopoly in 2003, the government awarded an exclusive service contract and loan guarantees to a private telecommunications company (INTELCO), whose founder and owner was the chairman of the DFC. To enable INTELCO to actually operate, the government re-acquired BTL, established an interconnection agreement between INTELCO and BTL, and re-sold BTL to a private U.S. company. However, this company later defaulted on its payments, forcing the government to acquire BTL for a second time. The government finally sold BTL back to its original owner, albeit at a significant discount. INTELCO failed, and the government assumed its foreign obligations of US\$20 million. Legal disputes related to the involved transactions are still ongoing.

Two high-profile investigations were initiated in 2005 to shed light on the operations of the SSB and the DFC, respectively. While the investigation of a Senate commission on the SSB was completed in July 2006, the work of an independent commission of inquiry to investigate the DFC is ongoing. The Report of the Senate Select Committee Investigating the Social Security Board can be accessed under www.belize.gov.bz. One of the report's key recommendations was the removal of the SSB's Chairman and General Manager, which the government promptly implemented. 
Text Table 3. Authorities' Response to Key Policy Recommendations in Previous Article IV Consultations

\begin{tabular}{|c|c|}
\hline Key IMF Recommendations & Authorities' Response \\
\hline $\begin{array}{l}\text { - Undertake a comprehensive and sustained fiscal } \\
\text { correction and maintain tight monetary policies to } \\
\text { reestablish a viable external position and avoid a } \\
\text { disorderly exit from the exchange rate peg. }\end{array}$ & $\begin{array}{l}\text { - The authorities were initially slow in addressing the } \\
\text { imbalances. However, in FY05/06 (April to March) the } \\
\text { central government's overall deficit fell sharply and } \\
\text { monetary policy was tightened. }\end{array}$ \\
\hline $\begin{array}{l}\text { - Develop and implement expeditiously a medium-term } \\
\text { debt strategy. }\end{array}$ & $\begin{array}{l}\text { - A financial advisor was hired in } 2005 \text {, and the } \\
\text { authorities decided on a debt strategy, which includes } \\
\text { offering a debt exchange to external private creditors } \\
\text { later this year. }\end{array}$ \\
\hline $\begin{array}{l}\text { - Close the DFC and put in place a transparent and } \\
\text { orderly mechanism to dispose of its portfolio. }\end{array}$ & $\begin{array}{l}\text { - The DFC has stopped lending and begun to divest } \\
\text { its assets. The authorities are currently working with } \\
\text { the IDB on a strategy for an orderly liquidation of the } \\
\text { remaining DFC assets. }\end{array}$ \\
\hline - Strengthen financial sector supervision. & $\begin{array}{l}\text { - Resources for bank supervision have been } \\
\text { increased, and credit unions have been brought under } \\
\text { central bank oversight. However, the independence of } \\
\text { bank supervisors remains weak, and there are very } \\
\text { few resources for insurance supervision. }\end{array}$ \\
\hline
\end{tabular}

\section{RECENT DEVELOPMENTS}

\section{Forceful stabilization policies were implemented in the context of the $2005 / 06$} budget (April to March). The overall deficit of the central government fell sharply from 8.6 percent of GDP in FY04/05 to 3.3 percent of GDP in FY05/06, while the primary balance shifted from a small deficit to a surplus of 3 percent of GDP. These improvements stemmed from revenue measures taken in May 2005, as well as from cuts in capital expenditures and lower debt service costs. ${ }^{1}$ On July 1, 2006 a general sales tax (GST) was introduced to replace the existing sales tax, which was applied on goods and services for importers and domestic producers and suffered from cascading effects and lack of buoyancy. ${ }^{2}$ The authorities also tightened liquidity by channeling social security deposits to the central bank starting in May 2005, and by increasing the cash reserve and liquid asset requirements in three steps of 1 percentage point each between May 2005 and September 2006 to 10 percent and 23 percent, respectively. These measures have helped slow the growth rate of credit to

\footnotetext{
${ }^{1}$ Some $23 / 4$ percent of GDP in exceptional fees and commissions on external loans that were incurred in FY04/05 were not repeated in FY05/06. The authorities also corrected a number of misclassifications in their fiscal records, which led to a shift of about $1 / 4$ percent of GDP in expenditure items from capital to current expenditure.

${ }^{2}$ The GST is a tax on final consumption and akin to the value-added tax. It is collected at every stage of the value-added chain and provides for credits for taxes paid at earlier stages of production.
} 
the private sector to about 6 percent during the 12 months ending in July 2006, from 10 percent during the previous 12-month period.

6. Partly in response to the tighter policy stance, the external current account deficit is expected to narrow in 2006. The projected improvement is driven by a reduction in the trade imbalance, as merchandise exports are expected to grow by some 30 percent while import growth decelerates. Moreover, tourism earnings are buoyant, and the income account has improved owing to lower commissions and fees from public debt operations.

7. The remaining balance of payments financing needs for $\mathbf{2 0 0 6}$ are likely to be covered through inflows from foreign direct investment, bilateral financial assistance, and some further reserves drawdown. Belize continues to attract sizeable foreign direct investments, particularly in the expanding tourism sector, and bilateral financing at belowmarket terms of US\$35 million has been obtained in 2006 from Taiwan Province of China and Venezuela. Notwithstanding these inflows, the balance of payments is still forecast to close the year with a deficit of some US\$10 million, which would cause gross reserves to fall below US\$50 million, or about three weeks of import coverage by end-year.

\section{Policy Discussions}

8. Discussions focused on measures to contain the risk of a near-term payments crisis, and on the development of a framework to accomplish a gradual return to medium-term sustainability. Staff noted that Belize's high public debt burden and fragile balance of payments were a major source of vulnerability and a constraint on growth. Although considerable progress had already been made in tightening policies, further steps still seemed necessary to address the immediate risk of a balance of payments crisis. At the same time, if the adjustment were to be sustainable, a collaborative resolution of the debt burden facing the country seemed necessary, along with steps to strengthen the authorities' fiscal and monetary policy implementation capacity and to facilitate strong growth.

9. Staff and the authorities agreed that the balance of payments outlook for 2007 and beyond remains worrisome and that further measures were needed.

- $\quad$ A passive scenario, assuming broadly unchanged policies, with a constant primary surplus of about 3.3 percent of GDP, no new multilateral lending, and the current debt service profile, shows that Belize's balance of payments financing needs would approach 10 percent of GDP in 2007 and average about 63/4 percent of GDP during 2008-11 (Tables 7 and 8). While the trade deficit is projected to remain relatively contained, with the effect of the withdrawal of EU trade preferences for bananas and sugar partly offset by a pickup in oil exports, scheduled public debt service 
obligations are high and rising over time, and would weigh heavily on the overall balance of payments. ${ }^{3}$

- Market financing sufficient to fully bridge the large projected gaps is unlikely to be forthcoming, given Belize's already high external public debt burden. Moreover, even if financing were to be available, at current market terms its cost would worsen the debt dynamics and exacerbate the economy's vulnerability to adverse shocks (Table 8 and Appendix VIII).

- In the authorities' view, bridging the remaining financing gaps through additional policy tightening alone would be neither feasible nor advisable. The authorities' main concern was that further large domestic adjustment, beyond what had already been achieved, would precipitate an excessive contraction of the economy and heighten social tensions.

10. In light of this difficult financing outlook, the government announced in August 2006 its intention to put the public debt on a sustainable footing through a debt restructuring based on a cooperative agreement with external commercial creditors. ${ }^{4}$ In the announcement, the authorities also expressed willingness to recognize and work with a formal creditors' committee representing holders of at least 51 percent of the affected debt. ${ }^{5}$ Bond prices slumped after the authorities' announcement, but recovered later to their preannouncement level of about 7580 cents to the dollar (Text Figure 3). The authorities have remained current on their debt obligations, but in mid-

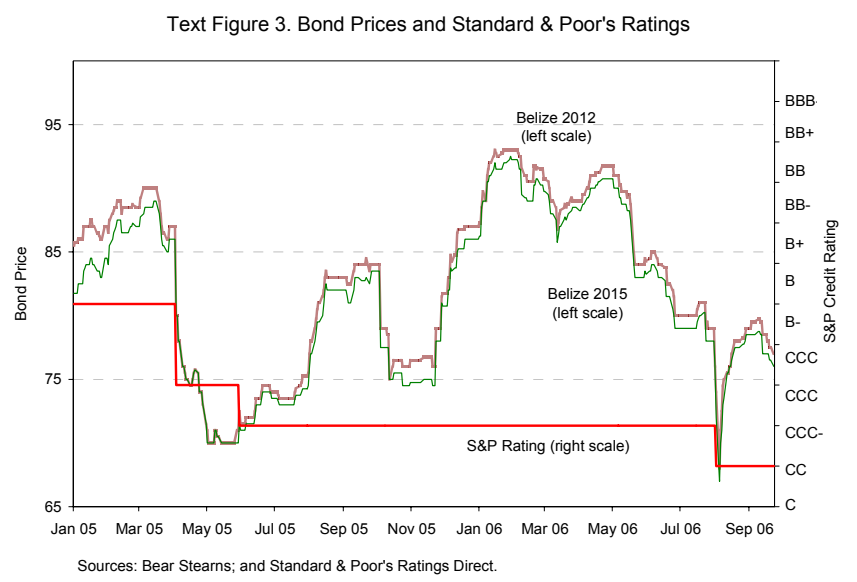
September they announced that debt

\footnotetext{
${ }^{3}$ Chapter I of the companion Selected Issues paper discusses the nature and impact on Belize of EU preference erosion for bananas and sugar.

${ }^{4}$ The authorities do not intend to restructure their bilateral, multilateral, and domestic debt. However, as part of their strategy they are seeking to mobilize additional financing at below-market terms from bilateral and multilateral creditors. Private external commercial debt amounts to about 50 percent of GDP. For an overview of the public debt structure see Table 3 and Appendix VII.

${ }^{5}$ However, to date, creditors have not notified the authorities about the formation of such a committee. The authorities' communications with creditors are posted on www.centralbank.org.bz.
} 
service payments to two special purpose vehicles, which form part of an issuance of insured bonds, had not been made. ${ }^{6}$ The government explained that this action was driven by the country's acute liquidity difficulties and the need to conserve the very limited pool of useable reserves. At the same time, the authorities reiterated their intention to use their best efforts to continue normal debt service, pending an orderly restructuring of the debt later this year. The authorities, through their financial advisors, have started a first round of consultations with individual creditors, and hope to conclude the restructuring by the end of 2006.

\section{A. Addressing Immediate Risks}

11. The mission emphasized the need for the authorities to take further steps in the short term to contain domestic demand and demonstrate their commitment to sound policies. Although it seemed unlikely that monetary and fiscal policy tightening alone could be sufficient to close the balance of payments gaps projected in 2007 and beyond, some additional effort seemed feasible and would provide important breathing room as negotiations on the debt restructuring unfolded.

\section{Staff welcomed the September 2006 increase in reserve requirements, but} cautioned that liquidity conditions may have to be tightened further. In particular, staff expressed concern about some pick-up in excess liquidity and credit growth in the first half of 2006 (Text Figure 4), and underscored the risks that a liquidity overhang posed to the exchange rate peg. The team therefore called on the authorities to stand ready to take additional action if the latest tightening of reserve requirements proved insufficient to mop up excess liquidity. The authorities indicated their willingness to tighten further, if necessary, but were confident that the latest hike in reserve requirements would likely be sufficient. Indeed, liquidity was already fairly tight in most of the domestic banks, except for one institution, whose large reserve holdings appeared to be a by-product of corporate restructuring and were not expected to trigger a sharp expansion

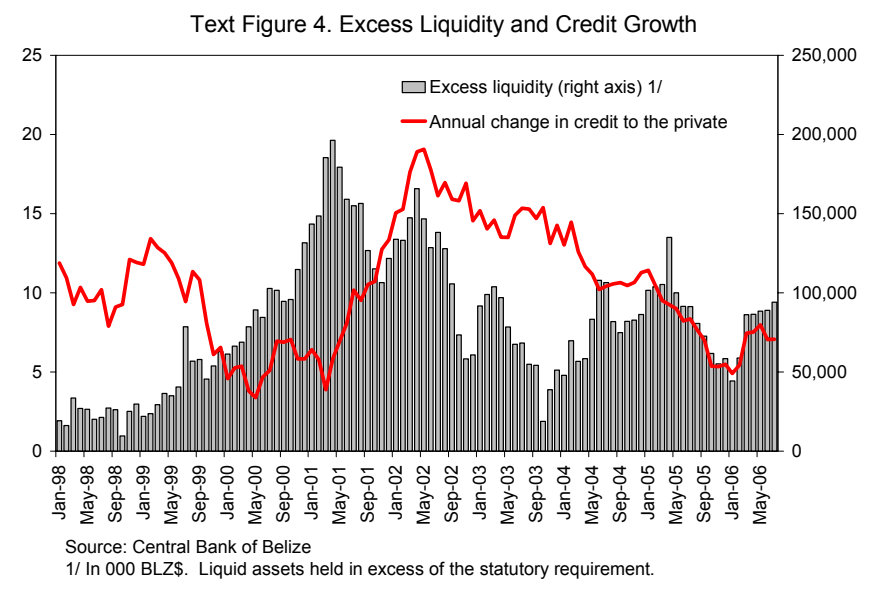
of credit in the near term.

\footnotetext{
${ }^{6}$ The structures of these two insured bond facilities was such that at inception, the government had to prepay six months of debt service into reserve accounts. The government's failure to make the scheduled payments triggered the use of these reserve accounts to make the scheduled payments to bondholders. To date, ratings agencies have not taken any action in response to the announcement.
} 


\section{The team also urged the authorities to contain the fiscal deficit in FY06/07 to} below the budgeted level. Recent fiscal developments had been very favorable, as AprilJune data showed that the FY06/07 budget target was well in hand, and initial estimates for revenue collection from the GST suggested that the implementation is proceeding satisfactorily. The oil sector was also beginning to yield tax revenue, and amendments to the Business and Income Tax Act that are in the process of being approved by Parliament would ensure that the government's take from this sector will be more in line with international comparators (Box 2). Staff called on the authorities to maintain the budget discipline shown in the first quarter in order to attain a primary surplus of $3 \frac{1}{2} 2$ percent of GDP in FY06/07 ( $1 / 2$ percent of GDP more than budgeted). This would require saving most of the additional revenue from oil production, continued restraint in current and capital expenditures, resisting pressures to dilute the GST base, and a willingness to take corrective measures should tax yields fall short of projections. The authorities agreed on the desirability of exceeding the budget target and felt that the proposed fiscal effort was feasible.

\section{B. Medium-Term Framework}

14. The team stressed that even if the more immediate financing needs were met, a long period of adjustment would still be needed to ensure debt sustainability. Especially given Belize's vulnerability to natural disasters and terms-of-trade shocks, the objective should be to close fiscal and balance of payments financing gaps through 2012, rebuild a reserve cushion of at least $2 \frac{1}{2}$ months of import coverage by 2015 , and reduce the debt burden to below 50 percent of GDP. The implementation of sound macroeconomic policies under such a framework would set the stage for gradually higher levels of capital inflows and investment, and more broadly a resumption of sustainable and steady growth.

\section{To illustrate these points, staff elaborated a scenario reflecting the impact of} active policies (Appendix VI and Table 9). Key elements of this framework include:

- Additional fiscal effort: Relative to the passive scenario, the mission proposed a front-loaded additional fiscal effort of about 1 percent of GDP (Text Figure 5). This should allow the authorities to achieve a primary surplus of $4 \frac{1}{2}$ percent of GDP during 2007-09 and slightly less thereafter. Maintaining higher primary surpluses would initially require saving the bulk of the revenue accruing from oil

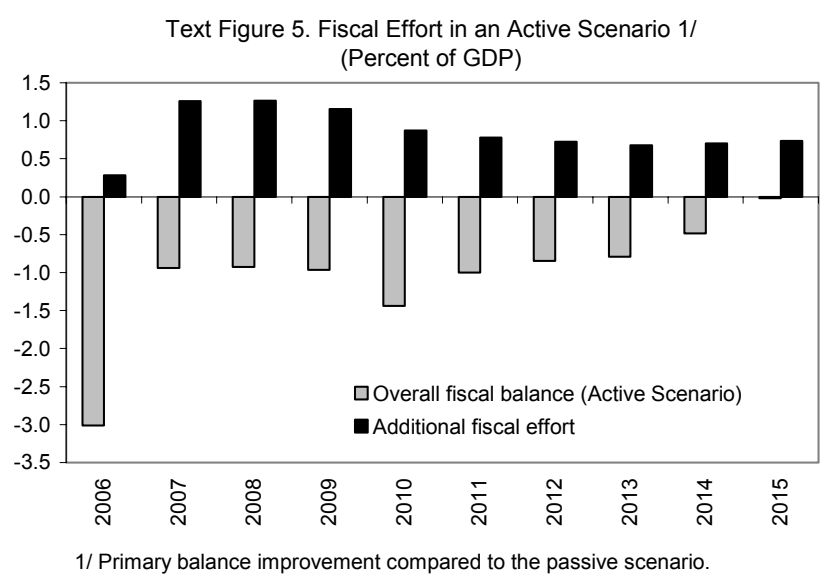
production. Over the 


\section{Box 2. The Oil Sector}

After a long history of unsuccessful oil explorations, in 2005 a company owned by Irish and U.S. investors (BNE) finally made the first commercial oil discovery in western Belize. Light sweet crude oil (comparable to West-Texas Intermediate) is currently flowing from the field at a rate of about 2,700 barrels per day. The proven recoverable reserves from this first find of about 10 million barrel - while small by industry standardsare significant for a country of the size of Belize in terms of value added to the economy, government revenue, and export earnings:

- Contribution to growth: At the current rate of production, annual output is estimated to reach about 800,000 barrels in 2006 and about one million barrels in 2007. Thereafter, annual production is expected to decline at a rate of about 10 percent per year through 2015, and production costs are expected to increase as the field is depleted. The net contribution of the oil production sector to economic growth is estimated to be 4.3 percent in 2006 and 0.8 percent in 2007. As production declines in the years thereafter, the contribution to growth will turn negative, ranging from -0.6 percent in 2008 to -0.3 in 2015.

- Fiscal take: The fiscal regime for the extraction of oil is negotiated individually for each exploration license on the basis of a production sharing agreement (PSA) that spells out tax and nontax payments. The PSA with BNE includes an option for the government to acquire an equity share ("working interest") of 10 percent, which the government has already exercised. The PSA also stipulates a royalty payment of 7.5 percent on BNE's share of gross sales (of which 0.375 percent is payable to the landowners), and a production share of 1.5 percent of net petroleum (i.e., gross sales less royalty payments and operation expenditures that include recovery of exploration costs). Finally, the PSA provides for income tax payments as specified in the Business and Income Tax Act. Amendments to the Business and Income Tax Act that are in the process

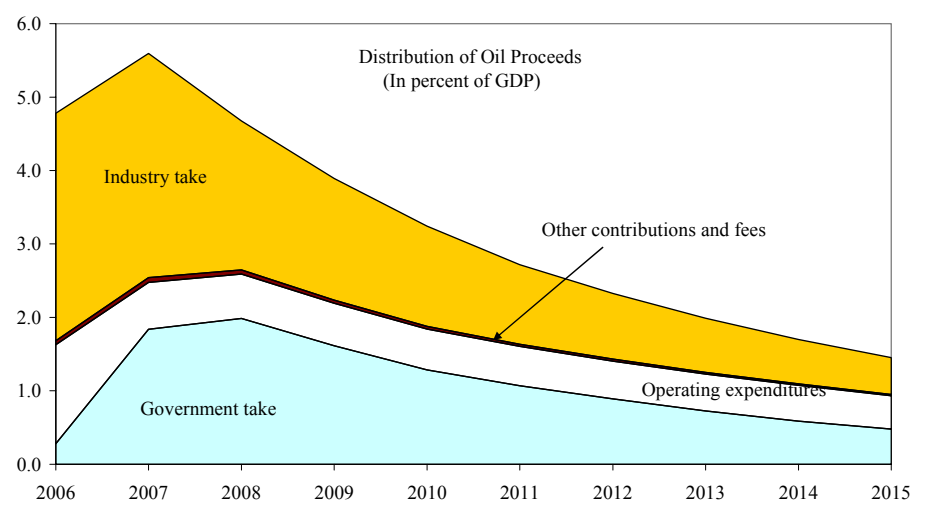
of being passed by Parliament set a special corporate income tax rate for oil production at 40 percent. These amendments bring Belize's otherwise low fiscal take from oil production more in line with international comparators. Subject to a number of assumptions on price, production levels, exploration costs, and ongoing investments, staff projects that the government's total revenue from oil production will peak at just under 2 percent of GDP in 2008 and gradually fall to $1 / 2$ percent of GDP by 2015 .

- Export proceeds: Currently almost all of Belize's crude oil is exported to neighboring countries in Central America and the Caribbean. In line with expected production, export proceeds are projected to reach their highest level of 51/2 percent of GDP in 2007 and gradually decline to below 2 percent of GDP by 2015. In terms of net retention, staff assumes that, particularly in the early years, most of BNE's net profits will be reinvested in exploration and development in Belize, and only about one-quarter will be transferred abroad in the form of income repatriation.

- Other exploration efforts: Geological conditions appear promising in a number of areas, bearing potential for further oil discoveries in the future. There are currently seven foreign and two local firms undertaking oil exploration across the country. However most of them are still at an early stage of taking geological surveys. 
medium term, an additional adjustment in the non-oil fiscal balance of about $1 / 2$ percent of GDP would also be needed. Moreover, the quality of the fiscal adjustment should be strengthened by keeping growth of non-interest current expenditure, particularly the wage bill, below that of nominal GDP, while allowing for a modest increase in capital spending for social sectors and infrastructure.

- Continued monetary restraint: Monetary policy should aim at preserving the exchange rate peg through controlling domestic demand growth. With broad money assumed to rise in line with the economy's expansion, the targeted build-up in net international reserves would require containing private sector credit growth below the growth rate of nominal GDP.

- Mobilization of additional bilateral and multilateral support: A credible mediumterm framework could be expected to garner additional support from bilateral and multilateral lenders. In this context, the authorities are currently working on securing approval of two policy-based loans of US\$25 million each from the IDB and CDB to be disbursed during 2006-08, as well as additional bilateral financing at belowmarket terms (Appendices III and IV).

16. While this package would significantly reduce financing needs, remaining fiscal and balance of payments gaps would still need to be addressed, including in the context of the debt restructuring operation.

These remaining financing needs are significant, averaging more than $61 / 2$ percent of GDP through 2012 for the balance of payments (Text Figure 6 and Table 9). The precise downward trajectory of the debt-to-GDP ratio would depend on the terms at which these gaps can be filled. ${ }^{7}$

\section{The authorities broadly} concurred with the thrust of the

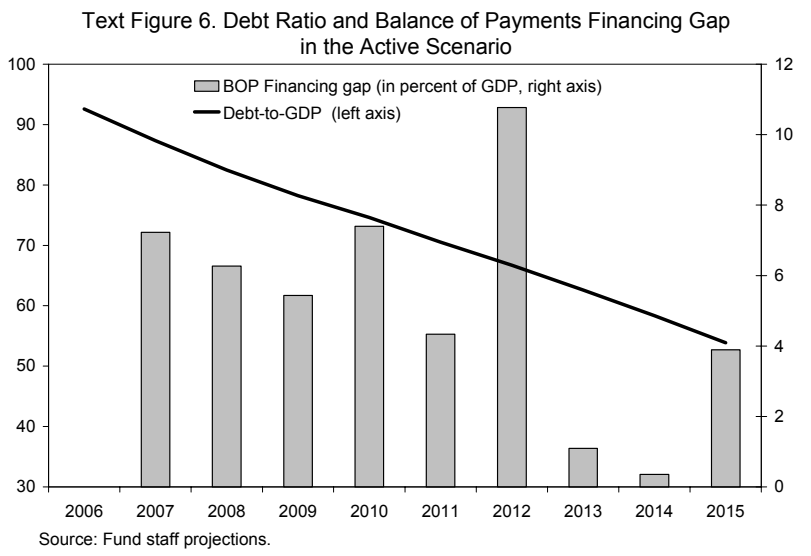
staff's analysis and the medium-term framework. They reiterated their strong commitment to put the required policies in place that would allow a return to fiscal and balance of payments sustainability. In their view, the revenue expected from the oil sector would be used to achieve a further narrowing of the fiscal deficit in the short term, without adversely affecting economic activity, and they were confident that this adjustment could be

\footnotetext{
${ }^{7}$ Closing the financing gaps through financing at estimated market terms would only reduce the debt-to-GDP ratio to about 54 percent by 2015 (Table 10).
} 
largely maintained in the medium term, including as a result of prudent expenditure management and some gradual improvements in non-oil revenue collection.

\section{Staff stressed that even in a favorable scenario substantial vulnerabilities would} remain for quite some time. In particular, oil-related revenues were uncertain as forecasts for world prices and Belize's reserves are subject to wide margins of error, and the team strongly cautioned against over-optimism. In addition, the debt burden would remain relatively high and its dynamics vulnerable to shocks, as shown in the staff's debt sustainability analysis (Appendix VIII). The mission therefore underscored, and the authorities acknowledged, the importance of avoiding policy slippage and taking early corrective actions in response to adverse changes in the domestic and external environments.

\section{Supportive Structural Reforms}

19. The large fiscal and monetary effort that is envisaged in the active scenario needs to be supported by structural reforms. The mission outlined reforms in the fiscal and monetary areas that would buttress the required macroeconomic discipline, reduce vulnerabilities, and add credibility to the adjustment plan.

\section{Reforms in the fiscal area}

20. The mission pointed to the need to improve the buoyancy and stability of non-oil tax revenue, including through modernizing tax administration, broadening the tax base, and reforming fuel and oil taxation. In particular:

- The tax administration's organization should move away from the current "tax type" model towards a more efficient functional model, in which activities and resources are consolidated based on business processes and commonality of function, such as audit, enforcement of tax collections, and taxpayer services. Such reform would complement the implementation of the GST, and technical assistance from the IMF and CARTAC for this purpose is already scheduled for later this year.

- The tax base should be expanded through eliminating business tax holidays under the Fiscal Incentives Act, terminating discretionary import duty exemptions, and replacing cumbersome import licensing procedures with tariffs. These reforms would also improve transparency, by removing some of the most discretionary elements of the tax system.

- $\quad$ The current variable revenue replacement duty for fuel imports should be replaced by a specific excise tax on fuel consumption that would apply for both domestic and imported fuel, coupled with the introduction of an automatic fuel price adjustment mechanism to ensure that changes in international oil prices are passed on to the 
consumer. ${ }^{8}$ While these changes would not be expected to generate additional revenue, they would promote greater revenue stability.

The authorities expressed strong commitment toward strengthening tax administration and recognized the need to bring the tax burden on the consumption of domestically produced oil in line with that of imports. Given the volatility in oil prices, they also agreed that there was merit in stabilizing revenue from the taxation of fuels.

\section{Although the proposed revision of the income tax regime for oil companies will} bring revenue from this sector closer to international standards, the fiscal regime for the petroleum sector could be strengthened further. The mission advised the authorities to consider changes to the standard production sharing agreement in order to increase its progressivity. ${ }^{9}$ The authorities agreed, and explained that they were studying possible instruments to achieve higher progressivity, such as a resource rent tax and others. In addition, the authorities noted that they were considering the establishment of a petroleum revenue fund. Staff agreed that a petroleum fund could be a useful device for accounting transparently for oil-related revenues, but emphasized that the design of any such arrangement should protect the integrity of the budget as the sole mechanism to allocate public expenditure. More generally, any such fund should serve to facilitate rather than defer the needed fiscal adjustment.

\section{On the expenditure side, staff cautioned that the noncontributory pension plan} for public officers (PPO) was creating large contingent liabilities and required urgent reform (Box 3). PPO expenses have been increasing at an average annual rate of 15 percent in the last six years, reaching 1.8 percent of GDP in FY05/06, and are Text Figure 7. Civil Service Pension Liabilities (Percent of GDP) expected to continue to grow rapidly (Text Figure 7). Staff urged the authorities to address these unfunded liabilities at an early stage, including through a phasing-out of the PPO for new entrants, as well as by introducing parametric reforms. The authorities were mindful of the fiscal risks from the PPO, but cautioned that its reform required a broad political and social

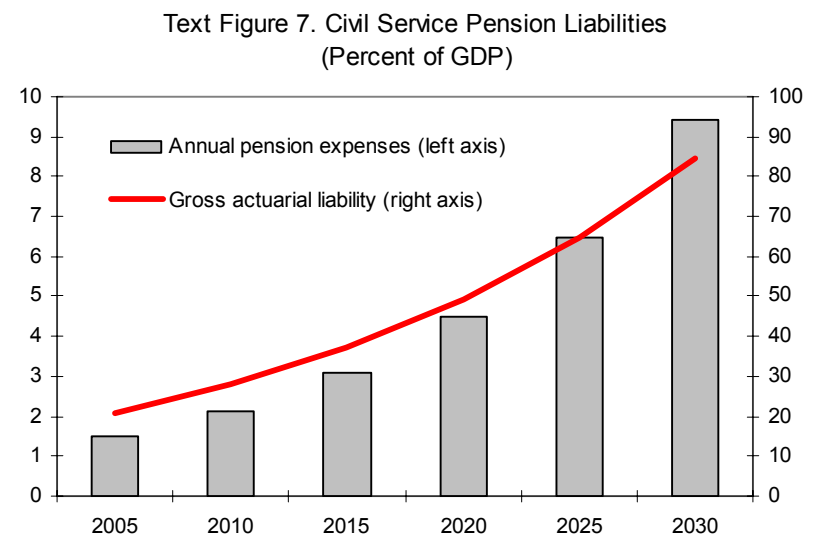

\footnotetext{
${ }^{8}$ For a discussion of the current revenue replacement duty see IMF Country Report No. 05/352.

${ }^{9}$ Under the current standard production sharing agreement, government revenue rises less than proportionally with the profitability of oil production. This is neither desirable from a fiscal perspective, nor from the standpoint of encouraging oil exploration.
} 


\section{Box 3. Belize's Social Security System}

Belize has two public pension schemes, one that is part of the general Social Security System (SSS) and a pension plan for public officers (PPO).

The SSS is a contributory partially funded defined benefit scheme that is based on a scaled premium system of finance (i.e., contributions are adjusted over time to ensure that expected premium and investment income do not fall short of the cost of benefits and administration). It provides retirement pensions from age 60 for those with contributions of at least 10 years, up to a maximum of 60 percent of the highest three years of earnings in the last 15 years. As of end-2005, the SSS had accumulated reserves of about US\$150 million and the most recent actuarial report (from 2002) indicated that the current financing bases of the scheme could be maintained for several years. However, contributions and other parameters of the system, such as income ceilings and possibly the retirement age, will need to be adjusted over time, if financial equilibrium is to be maintained.

The PPO is an unfunded, noncontributory defined benefit scheme. It provides retirement pensions from age 55 for public officers with at least 10 years of service up to a maximum of 67 percent of the average earnings in the last three years of service. Because the PPO is additional to the SSS, public officers may obtain combined replacement rates of more than 100 percent of their average salary. Pension benefits are not indexed but adjusted on an ad-hoc basis by the government. Between 1991 and 2005 the average compounded rate of pension adjustment has been 4.4 percent per year.

The PPO harbors major liabilities for the government. Because of its non-contributory nature, all expenses are covered from the central government budget. PPO expenses have been growing at an average annual rate of 15 percent in the last six years, reaching 1.8 percent of GDP (or 15 percent of total personnel expenditures and 8 percent of total tax revenue) in FY 2005/06. According to the most recent actuarial evaluation (of July 2004), the present value of obligations from pensions already being paid was about 11 percent of GDP. The projected total benefit obligations, which include future obligations for the currently active staff, were estimated at more than 20 percent of GDP. If the system was to remain in place as is, these actuarial liabilities would rise fourfold within 25 years, while pension expenses in the budget would increase to more than 9 percent of GDP.

Urgent reforms are needed to limit the accrual of additional government liabilities from the PPO. Ideally, the PPO should be phased-out for new entrants, who would in the future be covered solely by the SSS. This would avoid situations of exceedingly high income replacement ratios. If the replacement rates offered by the SSS were deemed insufficient for attracting qualified personnel, the government could consider the introduction of a complementary defined contribution scheme, as is in use by a number of other public entities in Belize, including the central bank. In addition, the government should explore the feasibility of parametric adjustments to the PPO. Measures that would have a more immediate financial impact include the introduction of contribution payments and the establishment of a ceiling on combined PPO and SSS benefits. Other possible adjustments that would likely reduce costs in the long run include increasing the minimum service period and retirement age, and lowering the rate of pension accrual for each year of service. 
consensus and would therefore be a challenging undertaking. Taking note, the staff encouraged the authorities to initiate a public debate as a first step in a longer reform process. The team also suggested that transition mechanisms could play a useful role in overcoming resistance to reform.

23. The mission stressed the importance of strengthening governance in quasi-fiscal institutions to control contingent liabilities. It welcomed progress in this area, such as the reform of the Finance and Audit Act, and the formal inquiries into the dealings of the SSB and DFC. The priorities should now be to improve risk management practices at the SSB, including prohibiting direct (first tier) lending and other quasi-fiscal activities; maintaining close control over the financial performance of the recently renationalized water company; and winding up the activities of the DFC. ${ }^{10}$ In this context, staff stressed the importance of letting the DFC recover its loan portfolio without interference, and advised against granting any further across-the-board discounts to borrowers.

\section{Staff also pointed to benefits that could be reaped from strengthening asset-} liability management. Weak debt management practices in the past—which have manifested themselves in high financing costs, bunching of maturities, and currency riskhave contributed to Belize's debt problems. Therefore, the mission recommended that the authorities establish a debt management office; clearly define the objectives of the office and delineate the roles of its managers; establish an investors relations program; build over time a portfolio and a risk management framework to balance the trade-off between costs and risks; and develop transparent asset-liability management policies. ${ }^{11}$ Because of the limited available resources, capacity building and technical assistance will be important, including from the Fund.

\section{Reforms in the monetary area}

\section{Staff and the authorities agreed on the need to strengthen the central bank's} capability for monetary policy implementation. Currently, the principal instruments of monetary policy are the cash reserve and liquid asset requirements. More market-oriented instruments would facilitate liquidity management, while improving the allocative efficiency of the banking system. The team encouraged the authorities to consider introducing a standing liquidity deposit window or a mechanism to auction either central bank or treasury securities, and the authorities requested further technical assistance on these instruments.

\footnotetext{
${ }^{10}$ The authorities are discussing with the IDB a strategy on dealing with the DFC, which would be part of the conditionality of a program-based loan.

${ }^{11}$ Chapter II of the companion Selected Issues paper discusses these proposals in more detail.
} 


\section{Staff also suggested that the authorities either eliminate or at least sharply} reduce in due course the government's overdraft facility at the central bank. This would increase the central bank's control over monetary policy, improve its independence, and could strengthen its balance sheet, provided that the government retires the remaining overdraft balance with marketable securities.

\section{Sequencing of reforms}

27. The authorities generally agreed with the mission's recommendations, but cautioned that the country's administrative capacity was limited and explained that implementation would therefore need to proceed in a sequenced manner. Staff suggested focusing initially on the areas of tax policy and monetary instruments, where measures could be implemented fairly easily, while the modernization of tax administration, pension reform and the strengthening of debt management practices was likely to take somewhat longer to implement.

\section{Financial Sector Vulnerabilities}

28. Indicators-based analysis and sensitivity tests performed by staff suggest that the domestic banking system is generally sound, and relatively robust to various shocks. These included the direct impact of a public debt restructuring, since exposure of the domestic banks to the sovereign is small, and banks do not hold any external debt instruments that are potentially subject to restructuring. Moreover, stress tests reveal that high levels of bank capital provide a significant buffer against simulated shocks, such as sharp tightening of monetary policy, a sudden deterioration in the quality of loans, or even a devaluation. ${ }^{12}$

29. However, staff noted that loan-loss provisions were low by international standards and should picture of capital adequacy

(Text Figure 8). To address this deficiency, the mission proposed establishing a minimum provision of 20 percent for substandard loans, as well as setting clear rules for the valuation of loan collateral. ${ }^{13}$ The be raised to provide a more realistic

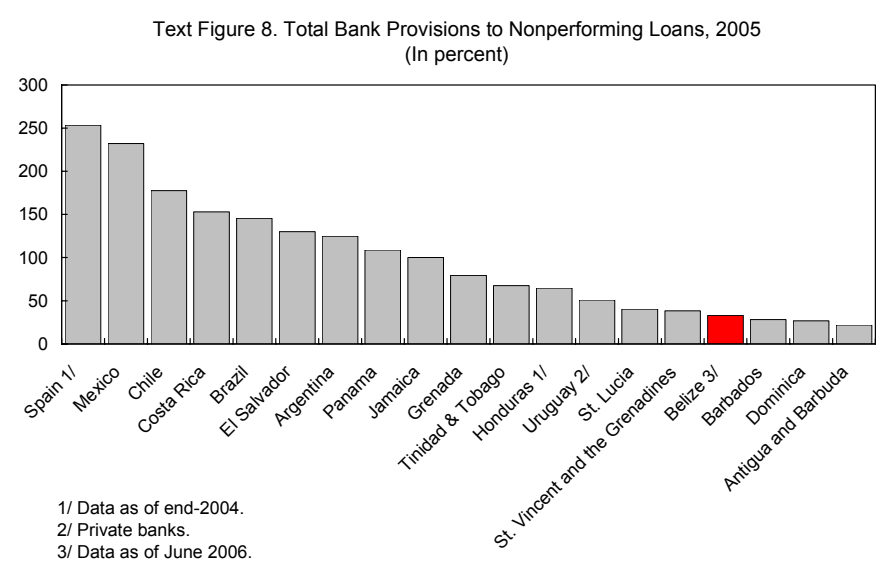

\footnotetext{
${ }^{12}$ Chapter III of the companion Selected Issues paper provides an detailed assessment of financial sector soundness in Belize.

${ }^{13}$ The provisioning requirements for doubtful and loss loans, which are 50 percent and 100 percent respectively, regardless of collateral, are broadly in line with international comparators.
} 
current levels of capitalization should allow banks to adjust to these changes fairly easily. ${ }^{14}$ The authorities indicated that they would promptly tighten the standards for loan-loss provisioning, as suggested by staff.

\section{Staff welcomed the progress that had been made in strengthening bank} supervision, but noted that further steps were necessary to foster a sound and resilient financial sector. Several recommendations of the IMF's 2003 Module 2 Offshore Financial Center Assessment have been implemented, such as substantially enhancing the resources of the Financial Sector Supervision Department at the central bank. ${ }^{15}$ However, the authorities still needed to further strengthen the operational independence of bank supervisors. Given Belize's vulnerability to natural disasters, the mission noted that a well-supervised property and business insurance sector was critical, including to avoid financial spillovers to the banking sector, and an increase in the resources for insurance supervision was urgently needed. The authorities appreciated the staff's assessment and noted that they were committed to implement the still outstanding recommendations of the OFC assessment, including through amendments of the Bank and Financial Intermediation Act and the Insurance Act, which are currently in preparation.

\section{E. Exchange Rate Regime and Competitiveness}

\section{The authorities' commitment to maintain the currency peg requires strict policy} discipline. Overall, backward-looking analysis does not point to the existence of a major competitiveness problem, as evidenced by the strong performance of Belize's exports of goods and services, the recent depreciation of the real effective exchange rate, and the absence of any significant parallel market pressures (Figure 2). Econometric analysis undertaken by staff also suggests that the real effective exchange rate level is currently close to its estimated equilibrium value (Text Figure 9). ${ }^{16}$ Staff recognized that the currency peg enjoyed wide popular support and has provided a helpful anchor for

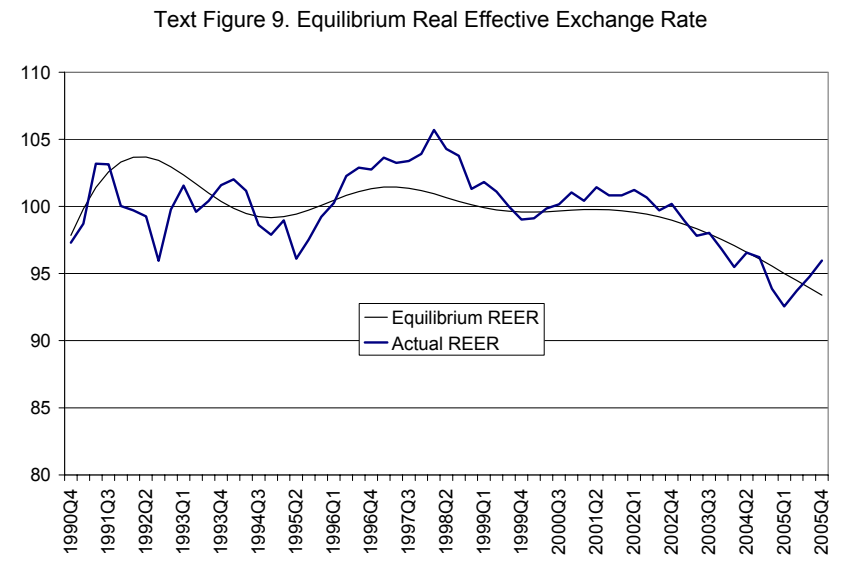

\footnotetext{
${ }^{14}$ The introduction of the proposed minimum provision would lower the system's average risk-adjusted capital assets ratio by about $3 / 4$ percentage point.

${ }^{15}$ See Chapter IV of the companion Selected Issues paper for a detailed assessment of the implemented recommendations.

${ }^{16}$ Details of this analysis can be found in Chapter V of the companion Selected Issues paper.
} 
expectations and inflation, especially given the country's small size and limited integration into international financial markets, and the fact that the United States is Belize's major trading partner and tourist market. Nonetheless, preserving the currency peg will necessitate the early adoption of a sustainable medium-term macroeconomic framework.

\section{F. Possible Fund Support}

32. The authorities remain committed to continue implementing a home-grown adjustment strategy without a formal Fund arrangement. Although the authorities recognized that a Fund-supported program would enhance the credibility of their reform efforts and could catalyze additional lending from bilateral and multilateral donors, they noted that their economic program had started to show tangible results in stabilizing the economic situation, and that its country-owned nature was important for regaining policy credibility and garnering domestic support. Therefore, the authorities' preference was to continue consulting closely with Fund staff and management, and to take advantage of Fund technical assistance in areas that are critical to their program, such as tax policy, tax administration, monetary policy, banking supervision, and economic data systems.

\section{Staff APPRAisal}

33. Belize's economy has reached a critical juncture. Overly expansionary macroeconomic policies during 1999-2004 contributed to a dramatic widening of current account deficits, an unsustainable build-up of public debt, and the erosion of international reserves. With large fiscal and balance of payments gaps projected to emerge from 2007 onward, there remains the need for policy action to address the still significant risk of financial and currency crises.

\section{The authorities have already made commendable strides in correcting} macroeconomic imbalances. The 2005/06 budget has achieved a significant fiscal correction, based on measures to increase tax collection, rein in discretionary current expenditure, and cut capital expenditure. Monetary conditions were also tightened through increases in the cash reserves and liquid assets requirements, which helped to slow private credit growth in 2005 .

\section{However, these efforts alone are not sufficient to bring the public finances and} the balance of payments back on a sustainable path. Assuming unchanged levels of fiscal effort, large fiscal and external financing gaps are likely to emerge in 2007 and beyond, mainly reflecting debt service obligations that are coming due in the period ahead. Closing such large financing gaps in an orderly way through further macroeconomic tightening alone does not appear feasible, and market financing of the required magnitudes is both unlikely to become available and would increase the debt service burden further. 
36. Encouragingly, the authorities have recognized the sustainability problem facing the country and are determined to address it. In this context, they have taken the difficult step to approach their private external creditors for debt relief and are seeking to mobilize multilateral and bilateral support, as part of a joint effort to bring Belize back on a path of sustainability, safeguard the currency peg, and create conditions for durable economic growth. Staff supports the authorities' intention to reach a cooperative agreement with private external creditors and notes that a sound strategy to achieve the outlined goals should seek to eliminate fiscal and balance of payments gaps through 2012, while allowing only modest gaps to prevail thereafter; reduce the public debt burden to less than 50 percent by 2015; and replenish international reserves coverage to about $2 \frac{1}{2} 2$ months of imports.

37. Macroeconomic policies should be further tightened in 2006 to mitigate immediate vulnerabilities and to demonstrate policy commitment. Staff welcomes the recent increase in reserve requirements, but the authorities must be prepared to take additional action if this proves insufficient to curb excess liquidity and contain private sector credit growth. In the fiscal area, staff urges the authorities to continue to outperform the budget target during the remainder of the fiscal year, in order to achieve a primary surplus of at least $3 \frac{1}{2}$ percent of GDP. For this, restraint in current and capital expenditure will be important, as will continued resistance to pressures to dilute the GST base.

38. A sustainable medium-term framework could build upon a combination of additional fiscal effort, continued monetary restraint, bilateral and multilateral financing, and relief from the envisaged debt operation. The authorities should increase the primary surplus by about 1 percent of GDP annually. This effort appears feasible and would be achieved initially by saving the bulk of the projected oil revenues, and subsequently by improvements in non-oil tax revenue collection and current expenditure restraint, as oil revenue tapers off. Monetary policy will need to be firm to continue to anchor the exchange rate peg, especially by keeping the growth rate of private sector credit below the expansion of nominal GDP. Moreover, support from bilateral, multilateral and private creditors will be key. The authorities should therefore seek to expeditiously reach a cooperative agreement with private creditors on a restructuring of their debt, and secure additional financing commitments from bilateral and multilateral lenders, as far as possible on concessional terms.

39. To help sustain the needed fiscal effort and monetary discipline over time, a set of supportive structural reforms should be implemented. In the fiscal area, these would include modernizing tax administration, broadening the tax base by eliminating exemptions and converting import licenses into tariffs, and reforming oil and fuel taxation. At the same time, the pension system for public officers should be reformed to cap spending increases, while the governance of quasi-fiscal institutions is strengthened, and an office for assetliability management and investor relations established. In the monetary area, the central bank's policy instruments should be broadened. Although administrative capacity limits may 
mean that structural reforms will have to be carefully sequenced, early actions could be taken in the areas of tax policy and monetary instruments.

40. Belize's banking system appears generally robust to a variety of shocks, but loan-loss provisioning requirements and valuation rules for loan collateral should be brought to international standards. While progress has been made in strengthening financial sector supervision, further steps are needed to fully implement the recommendations of the Offshore Financial Center assessment, particularly in the area of insurance.

41. The authorities are strongly committed to the fixed exchange rate regime, and the value of the Belize dollar appears broadly in line with medium-term fundamentals. The currency peg has served the country well and enjoys wide popular support, having provided a helpful anchor for prices and expectations. However, safeguarding the peg will ultimately depend on the durable implementation of a sustainable medium-term macroeconomic framework.

42. Even in the best of circumstances, Belize's economic and financial situation will remain highly vulnerable for quite some time, thus allowing little room for slippage in implementing the outlined policy framework. International reserves are projected to remain low and the debt burden high for several years, leaving the country exposed to adverse shocks. In addition, revenue estimates from oil are subject to a wide margin of error, and there is the risk that oil revenue dependency will develop. Therefore, it will be critical that policymakers manage these risks carefully and adjust early to any changes in the domestic and external environment.

43. Staff welcomes Belize's participation in the GDDS and encourages the authorities to continue to strengthen the quality and timeliness of the country's economic statistics.

44. The next Article IV consultation is expected to be held on the standard 12-month cycle. 
Figure 1. Belize: Macroeconomic Performance in a Regional Context, 1999-2005

Belize's growth performance has been very strong, albeit decelerating since 2003...

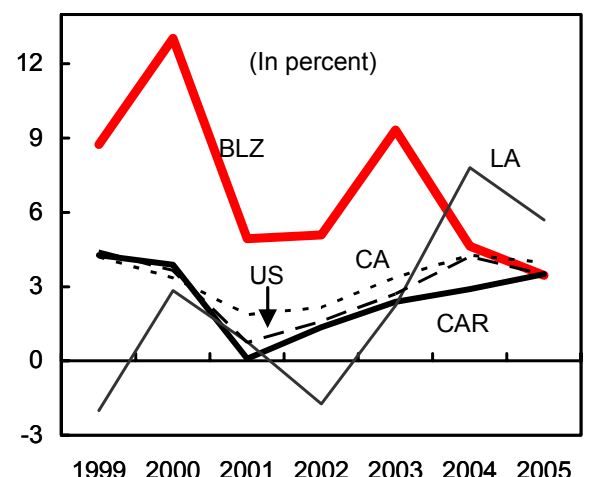

Growth has been driven in part by high levels of investment...

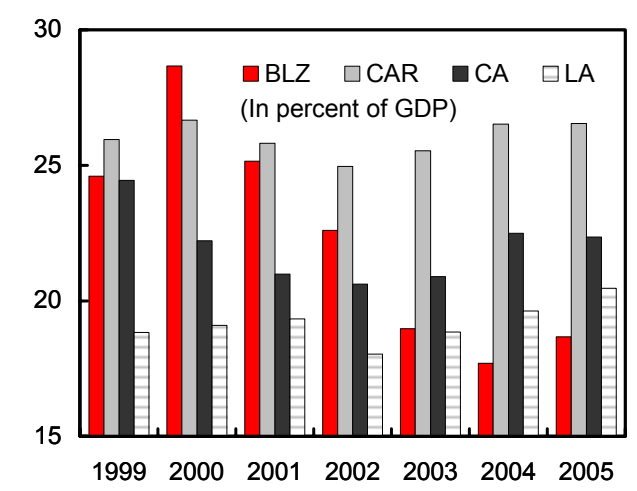

These current account deficits have been financed through rapidly rising public and publicly guaranteed external debt...

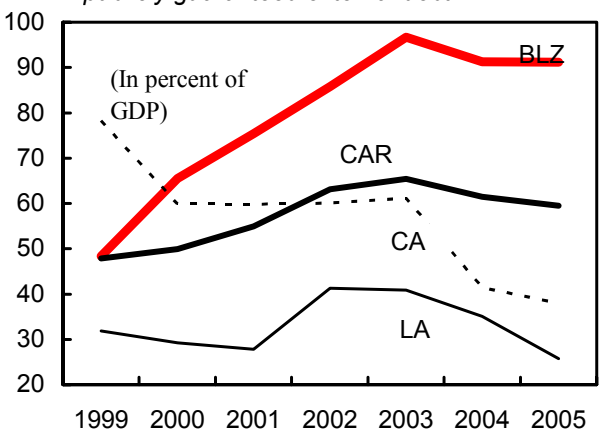

...while inflation has been low compared to other countries in the region.

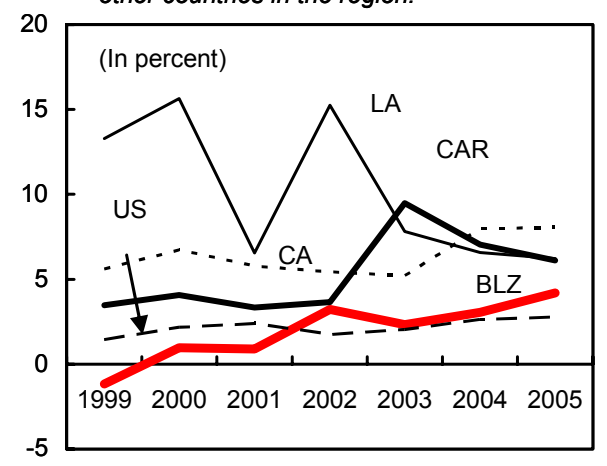

...which contributed to an unsustainable external current account deficit.

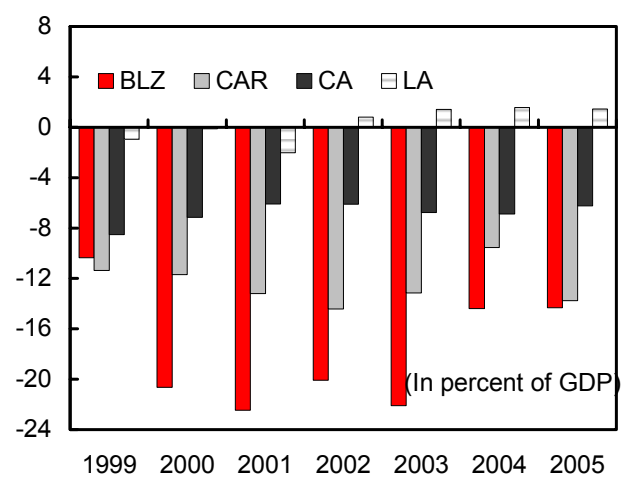

...leaving Belize among the most indebted emerging market countries.

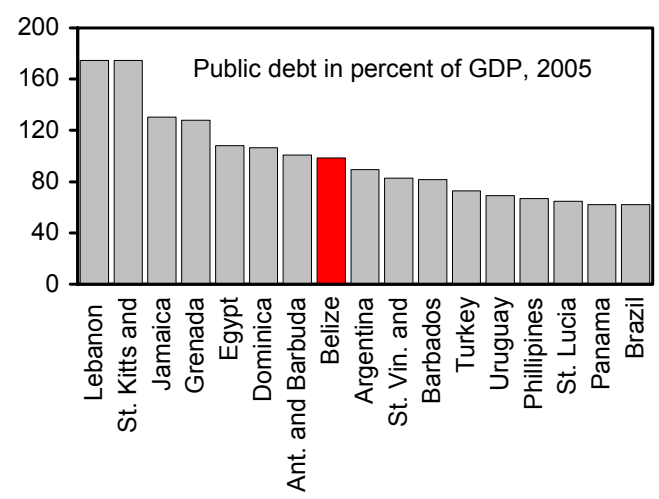

Source: Fund staff projections.

1/ The comparison includes Belize (BLZ) and the following regions: the Caribbean (CAR), Central America (CA), and other Latin American economies (LA; including Argentina, Brazil, Chile, Colombia, Ecuador, Mexico, Peru, Uruguay, and Venezuela). 
Figure 2. Belize: External Competitiveness

Belize's current account deficit has widened sharply since 1998, but there is little evidence to suggest that this deterioration was related to a competitiveness problem.

$\begin{array}{lllllll}1992 & 1994 & 1996 & 1998 & 2000 & 2002 & 2004\end{array}$

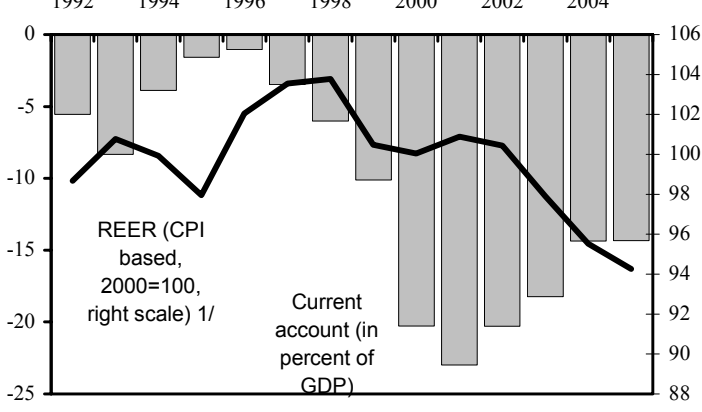

...alternative real exchange rate measures do not point to declining competitiveness...

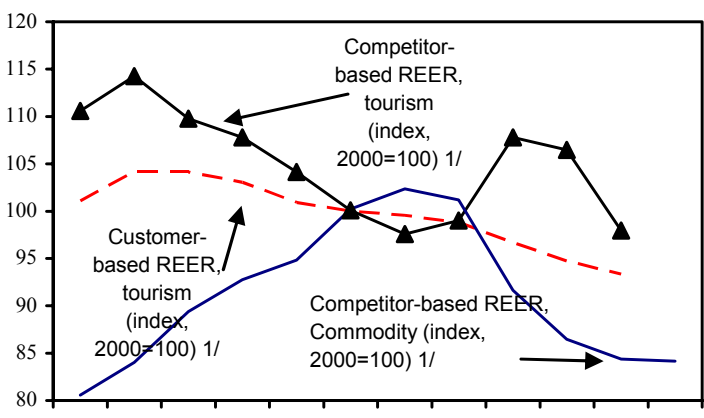

19951996199719981999200020012002200320042005

Instead, the current account imbalance is increasingly explained by a deteriorating income account that mirrors the sharp accumulation of foreign debt in recent years.

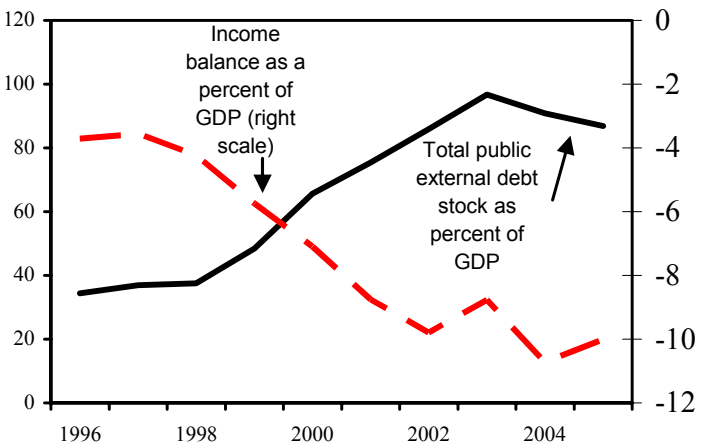

Export growth—while volatile-has been positive...

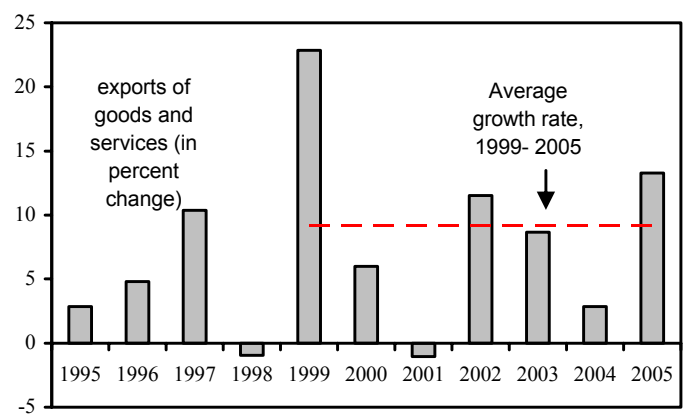

.... and cross-country evidence does not indicate that the domestic price level is misaligned.

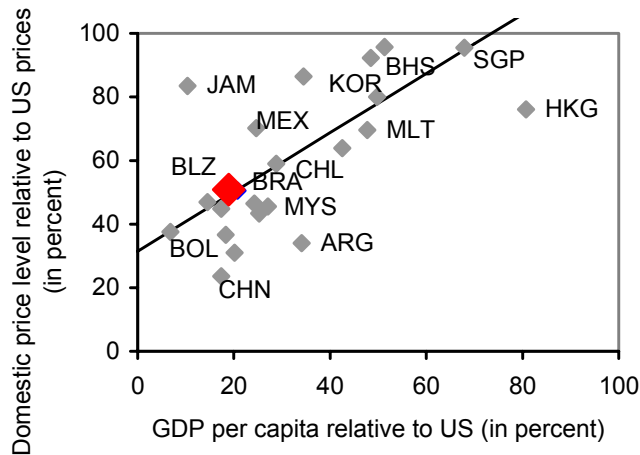

The current account balance that excludes the impact of income and oil shows a marked improvement in the last couple of years and is now significantly positive.

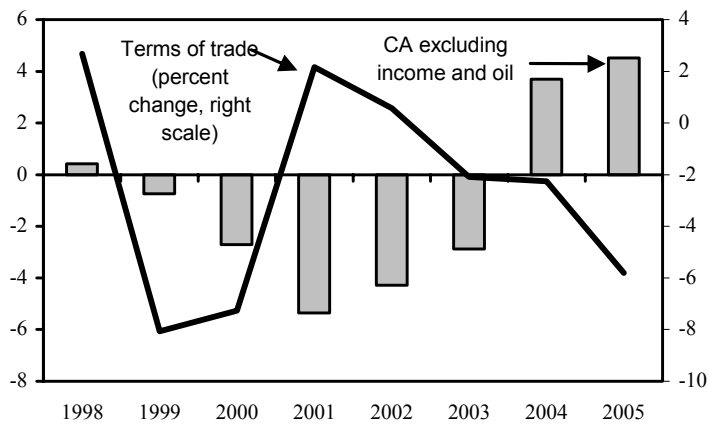

Sources: Caribbean Tourism Organization, Belize Tourism Board, Central Bank of Belize, and Fund staff estimates.

1/ An increase (decrease) represents appreciation (depreciation). 
Table 1. Belize: Selected Economic Indicators, 2003-07

\begin{tabular}{|c|c|c|c|c|c|}
\hline & \multirow[b]{2}{*}{2003} & \multirow[b]{2}{*}{2004} & \multirow{2}{*}{$\begin{array}{l}\text { Prel. } \\
2005\end{array}$} & \multicolumn{2}{|c|}{ Passive Proj. 1/ } \\
\hline & & & & 2006 & 2007 \\
\hline & \multicolumn{5}{|c|}{ (Annual percentage changes, unless otherwise indicated) } \\
\hline \multicolumn{6}{|l|}{ National income and prices } \\
\hline GDP at constant prices & 9.3 & 4.6 & 3.5 & 5.3 & 2.6 \\
\hline GDP deflator & -3.1 & 2.1 & 1.8 & 4.0 & 2.5 \\
\hline Consumer prices (end of period) & 2.3 & 3.1 & 4.2 & 4.4 & 2.8 \\
\hline \multicolumn{6}{|l|}{ External sector (U.S. dollars) } \\
\hline Exports of goods and services & 8.7 & 2.9 & 13.3 & 21.7 & 5.0 \\
\hline Imports of goods and services & 5.6 & -5.2 & 13.8 & 9.5 & 6.9 \\
\hline Terms of trade (deterioration -) & -2.0 & -2.5 & -5.9 & -3.7 & -1.3 \\
\hline Nominal effective exchange rate & -2.2 & -2.0 & -1.5 & $\ldots$ & $\ldots$ \\
\hline Real effective exchange rate & -2.5 & -2.4 & -1.3 & $\ldots$ & $\ldots$ \\
\hline \multicolumn{6}{|l|}{ Money and credit } \\
\hline Net domestic assets & 19.3 & 15.5 & 3.6 & 7.4 & 3.2 \\
\hline Credit to the private sector & 13.2 & 9.6 & 11.3 & 5.5 & 3.6 \\
\hline Money and quasi-money (M2) & 4.7 & 7.5 & 5.9 & 9.5 & 5.1 \\
\hline Weighted average lending rates (in percent) & 14.2 & 14.0 & 14.3 & $\cdots$ & $\cdots$ \\
\hline & \multicolumn{5}{|c|}{ (In percent of GDP) } \\
\hline \multicolumn{6}{|l|}{ Central government } \\
\hline Revenue and grants & 21.4 & 22.8 & 23.5 & 24.5 & 26.0 \\
\hline Of which: oil & 0.0 & 0.0 & 0.0 & 0.3 & 1.8 \\
\hline grants & 0.3 & 1.5 & 0.6 & 0.9 & 0.8 \\
\hline Current expenditure $2 /$ & 19.9 & 22.7 & 24.8 & 23.7 & 23.5 \\
\hline Capital expenditure and net lending & 12.1 & 6.5 & 4.1 & 4.1 & 5.2 \\
\hline Primary balance & -5.9 & 0.8 & 2.0 & 3.2 & 3.3 \\
\hline Overall balance & -10.6 & -6.4 & -5.5 & -3.3 & -2.6 \\
\hline Privatization & -5.2 & 0.0 & 2.3 & 0.4 & 0.7 \\
\hline Central government borrowing requirement & 15.8 & 6.4 & 3.2 & 2.9 & 1.9 \\
\hline Foreign financing & 18.8 & 1.8 & 4.3 & -0.2 & -7.3 \\
\hline Domestic financing & -3.0 & 4.5 & -1.2 & 3.1 & 0.4 \\
\hline Fiscal financing gap & 0.0 & 0.0 & 0.0 & 0.0 & 8.8 \\
\hline Gross domestic investment $3 /$ & 21.5 & 18.9 & 23.1 & 18.0 & 18.0 \\
\hline Gross national savings & 3.3 & 4.6 & 8.8 & 9.2 & 8.4 \\
\hline External current account 4/ & -18.2 & -14.4 & -14.3 & -8.8 & -9.6 \\
\hline Public and publicly guaranteed debt & 102.3 & 100.2 & 98.5 & 92.9 & 90.2 \\
\hline Domestic debt & 5.7 & 9.0 & 7.3 & 9.8 & 9.7 \\
\hline External debt & 96.7 & 91.2 & 91.2 & 83.1 & 80.5 \\
\hline Debt service 5/ & 19.3 & 22.8 & 21.0 & 12.4 & 16.5 \\
\hline In percent of exports of goods and services & 29.8 & 42.9 & 38.7 & 20.1 & 26.8 \\
\hline In percent of government current revenue & 76.8 & 105.0 & 94.1 & 52.4 & 65.4 \\
\hline & \multicolumn{5}{|c|}{ (In millions of U.S. dollars, unless otherwise specified) } \\
\hline Overall balance of payments $6 /$ & -30.1 & -31.3 & 18.0 & -9.3 & -112.7 \\
\hline Balance of payments financing gap & 0.0 & 0.0 & 0.0 & 0.0 & 122.7 \\
\hline Exports of goods and services & 527.6 & 542.8 & 614.8 & 748.4 & 785.7 \\
\hline Imports of goods and services & 661.7 & 627.1 & 713.9 & 781.7 & 835.8 \\
\hline Gross official reserves $7 /$ & 76.2 & 39.8 & 57.9 & 48.6 & 58.6 \\
\hline Nominal GDP & 987.6 & $1,055.2$ & $1,110.9$ & $1,216.8$ & $1,279.1$ \\
\hline
\end{tabular}

Sources: Belize authorities; and Fund staff estimates and projections.

$1 /$ Assuming foreign financing is forthcoming to fill the fiscal financing gaps.

2/ Including unidentified expenditures.

$3 /$ Including inventory accumulation and discrepancies.

4/ Including official grants.

5/ Public and publicly guaranteed external debt.

6/ Including financing gap.

7/ End of period. 
Table 2. Belize: Operations of the Central Government, 2003-07 1/

\begin{tabular}{|c|c|c|c|c|c|}
\hline & \multirow[b]{2}{*}{2003} & \multirow[b]{2}{*}{2004} & \multirow{2}{*}{$\begin{array}{l}\text { Prel. } \\
2005\end{array}$} & \multicolumn{2}{|c|}{ Passive Proj. } \\
\hline & & & & 2006 & 2007 \\
\hline & \multicolumn{5}{|c|}{ (In percent of GDP; unless otherwise indicated) } \\
\hline Revenue and grants & 21.4 & 22.8 & 23.5 & 24.5 & 26.0 \\
\hline Revenue & 21.1 & 21.3 & 22.9 & 23.6 & 25.2 \\
\hline Current revenue & 20.7 & 21.0 & 22.7 & 23.6 & 25.2 \\
\hline Tax revenue & 18.7 & 19.0 & 20.5 & 21.3 & 22.5 \\
\hline Of which: sales tax & & 5.3 & 5.8 & 5.7 & 5.6 \\
\hline Nontax revenue & 2.0 & 2.0 & 2.2 & 2.3 & 2.8 \\
\hline Capital revenue & 0.3 & 0.3 & 0.1 & 0.0 & 0.0 \\
\hline Grants & 0.3 & 1.5 & 0.6 & 0.9 & 0.8 \\
\hline Expenditure & 32.7 & 30.1 & 29.0 & 27.7 & 28.6 \\
\hline Current expenditure & 20.6 & 23.6 & 24.9 & 23.6 & 23.5 \\
\hline Wages and salaries & 9.5 & 9.8 & 10.0 & 9.1 & 9.4 \\
\hline Pensions & 1.4 & 1.5 & 1.8 & 1.7 & 1.7 \\
\hline Goods and services & 3.8 & 3.6 & 4.0 & 4.1 & 4.2 \\
\hline Interest payments, fees, and charges & 4.7 & 7.2 & 7.5 & 6.5 & 5.9 \\
\hline Domestic & 0.7 & 0.8 & 0.7 & 0.9 & 0.8 \\
\hline Foreign & 3.9 & 6.3 & 6.8 & 5.6 & 5.1 \\
\hline Interest & 3.9 & 4.9 & 5.6 & 5.1 & 5.1 \\
\hline Exceptional fees and charges & 0.0 & 1.5 & 1.1 & 0.5 & 0.0 \\
\hline Transfers & 1.4 & 1.5 & 1.6 & 2.2 & 2.2 \\
\hline Capital expenditure and net lending & 12.1 & 6.5 & 4.1 & 4.1 & 5.2 \\
\hline Capital expenditure & 9.7 & 6.7 & 3.8 & 3.9 & 5.2 \\
\hline Domestically financed expenditure $2 /$ & 4.7 & 2.8 & 2.3 & 2.8 & 3.0 \\
\hline Foreign financed expenditure & 5.0 & 3.9 & 1.5 & 1.1 & 2.2 \\
\hline Net lending & 2.4 & -0.2 & 0.3 & 0.3 & 0.0 \\
\hline Unidentified expenditure & -0.7 & -0.9 & -0.1 & 0.1 & 0.0 \\
\hline Overall balance & -10.6 & -6.4 & -5.5 & -3.3 & -2.6 \\
\hline Total financing & 10.6 & 6.4 & 5.5 & 3.3 & 2.6 \\
\hline Privatization & -5.2 & 0.0 & 2.3 & 0.4 & 0.7 \\
\hline Central government borrowing requirement & 15.8 & 6.4 & 3.2 & 2.9 & 1.9 \\
\hline Domestic & -3.0 & 4.5 & -1.2 & 3.1 & 0.4 \\
\hline Banking system & -2.6 & 4.7 & -1.0 & $\ldots$ & $\ldots$ \\
\hline Central bank & 3.9 & 3.5 & 0.0 & $\ldots$ & $\ldots$ \\
\hline Commercial banks & -0.1 & 0.9 & -1.0 & $\ldots$ & ... \\
\hline Refinancing DFC & -6.4 & 0.2 & -0.1 & $\ldots$ & $\ldots$ \\
\hline Nonbank & -0.4 & -0.1 & -0.1 & $\ldots$ & $\ldots$ \\
\hline External & 18.8 & 1.8 & 4.3 & -0.2 & -7.3 \\
\hline Disbursements & 25.3 & 19.9 & 18.4 & 4.5 & 2.7 \\
\hline Amortization & -5.1 & -11.7 & -13.4 & -5.1 & -10.0 \\
\hline Refinancing of DFC & 0.0 & -5.8 & -0.3 & 0.0 & 0.0 \\
\hline Contributions to sinking funds & -1.4 & -0.5 & -0.5 & 0.4 & 0.0 \\
\hline Fiscal financing gap & 0.0 & 0.0 & 0.0 & 0.0 & 8.8 \\
\hline \multicolumn{6}{|l|}{ Memorandum items: } \\
\hline Nominal GDP (in BZ\$ millions) & 1,975 & 2,110 & 2,222 & 2,434 & 2,558 \\
\hline Primary balance & -5.9 & 0.8 & 2.0 & 3.2 & 3.3 \\
\hline Oil revenue & 0.0 & 0.0 & 0.0 & 0.3 & 1.8 \\
\hline \multicolumn{6}{|l|}{ In fiscal years (April to March) } \\
\hline Revenue and grants & 22.5 & 22.0 & 24.2 & 25.5 & 26.0 \\
\hline Non-interest expenditures & 25.6 & 22.3 & 21.2 & 22.1 & 22.7 \\
\hline Primary balance & -3.1 & -0.3 & 3.0 & 3.4 & 3.3 \\
\hline Interest payments & 4.9 & 8.3 & 6.3 & 6.6 & 5.7 \\
\hline Overall balance & -8.0 & -8.6 & -3.3 & -3.2 & -2.4 \\
\hline
\end{tabular}

Sources: Ministry of Finance; Central Bank of Belize; and Fund staff estimates and projections.

1/ Calendar year.

2/ Including emergency and environmental expenditures. 
Table 3. Belize: Public and Publicly Guaranteed Debt, 2003-06

\begin{tabular}{|c|c|c|c|c|}
\hline & \multirow[b]{2}{*}{2003} & \multirow[b]{2}{*}{2004} & \multicolumn{2}{|c|}{ Prel. } \\
\hline & & & \multicolumn{2}{|c|}{2005 June 2006} \\
\hline & \multicolumn{4}{|c|}{ (In millions of U.S. dollars) } \\
\hline Debt outstanding (end-of-period) & $1,010.8$ & $1,057.4$ & $1,094.5$ & $1,088.4$ \\
\hline Domestic debt $1 /$ & 56.1 & 94.8 & 81.4 & 86.7 \\
\hline External debt & 954.6 & 962.6 & $1,013.1$ & $1,001.6$ \\
\hline Public sector debt & 899.2 & 885.6 & 965.0 & 955.7 \\
\hline Central government & 719.2 & 810.5 & 876.2 & 871.3 \\
\hline Commercial & 454.9 & 519.7 & 559.3 & 548.7 \\
\hline Multilateral & 145.2 & 160.2 & 159.9 & 158.0 \\
\hline Bilateral & 116.7 & 124.7 & 144.9 & 154.9 \\
\hline Export credit & 2.4 & 5.9 & 12.0 & 9.6 \\
\hline Nonfinancial public sector & 7.1 & 6.1 & 29.0 & 27.5 \\
\hline Financial sector & 172.9 & 69.1 & 59.8 & 56.9 \\
\hline CBB & 5.0 & 2.3 & 0.9 & 0.8 \\
\hline DFC & 167.8 & 66.7 & 59.0 & 56.1 \\
\hline Non-securitized & 32.0 & 30.0 & 25.9 & 24.9 \\
\hline Securitized & 135.8 & 36.7 & 33.1 & 31.2 \\
\hline \multirow[t]{2}{*}{ Publicly guaranteed external debt } & 55.4 & 77.0 & 48.1 & 46.0 \\
\hline & \multicolumn{4}{|c|}{ (In percent of GDP) } \\
\hline Debt outstanding (end-of-period) & 102.3 & 100.2 & 98.5 & 93.5 \\
\hline Domestic debt $1 /$ & 5.7 & 9.0 & 7.3 & 7.5 \\
\hline External debt & 96.7 & 91.2 & 91.2 & 86.1 \\
\hline Public sector debt & 91.1 & 83.9 & 86.9 & 82.1 \\
\hline Central government & 72.8 & 76.8 & 78.9 & 74.9 \\
\hline Commercial & 46.1 & 49.2 & 50.3 & 47.1 \\
\hline Multilateral & 14.7 & 15.2 & 14.4 & 13.6 \\
\hline Bilateral & 11.8 & 11.8 & 13.0 & 13.3 \\
\hline Export credit & 0.2 & 0.6 & 1.1 & 0.8 \\
\hline Nonfinancial public sector & 0.7 & 0.6 & 2.6 & 2.4 \\
\hline Financial sector & 17.5 & 6.5 & 5.4 & 4.9 \\
\hline CBB & 0.5 & 0.2 & 0.1 & 0.1 \\
\hline DFC & 17.0 & 6.3 & 5.3 & 4.8 \\
\hline Non-securitized & 3.2 & 2.8 & 2.3 & 2.1 \\
\hline Securitized & 13.7 & 3.5 & 3.0 & 2.7 \\
\hline \multirow[t]{2}{*}{ Publicly guaranteed external debt } & 5.6 & 7.3 & 4.3 & 3.9 \\
\hline & \multicolumn{4}{|c|}{ (In millions of U.S. dollars) } \\
\hline \multicolumn{5}{|l|}{ Memorandum items: } \\
\hline Nominal GDP & 987.6 & $1,055.2$ & $1,110.9$ & $1,163.9$ \\
\hline External debt by creditor type & & & $1,013.1$ & $1,001.6$ \\
\hline Commercial & & & 617.1 & 604.1 \\
\hline Multilateral & & & 228.6 & 224.0 \\
\hline Bilateral & & & 149.6 & 159.3 \\
\hline Export credit & & & 17.8 & 14.2 \\
\hline
\end{tabular}

Sources: Central Bank of Belize; and Ministry of Finance.

1/ Refers to central government. 
Table 4. Belize: Operations of the Banking System, 2003-07

\begin{tabular}{|c|c|c|c|c|c|}
\hline & \multirow[b]{2}{*}{2003} & \multirow[b]{2}{*}{2004} & \multirow[b]{2}{*}{2005} & \multicolumn{2}{|c|}{ Passive Proj. 1/ } \\
\hline & & & & 2006 & 2007 \\
\hline & \multicolumn{5}{|c|}{ (In millions of Belize dollars) } \\
\hline \multicolumn{6}{|l|}{ Central Bank of Belize (CBB) } \\
\hline $\begin{array}{l}\text { Net Foreign Assets } \\
\text { Net international reserves }\end{array}$ & $\begin{array}{l}139.1 \\
146.6\end{array}$ & $\begin{array}{l}74.3 \\
76.8\end{array}$ & $\begin{array}{l}113.0 \\
113.0\end{array}$ & $\begin{array}{l}94.4 \\
94.4\end{array}$ & $\begin{array}{l}114.4 \\
114.4\end{array}$ \\
\hline Medium-term foreign liabilities & -7.5 & -2.5 & 0.0 & 0.0 & 0.0 \\
\hline Net domestic assets & 64.5 & 155.7 & 142.4 & 179.9 & 172.7 \\
\hline Credit to the public sector (net) & 65.8 & 163.9 & 145.9 & 182.3 & 169.3 \\
\hline Central government & 59.3 & 134.0 & 134.6 & 194.6 & 199.6 \\
\hline Other nonfinancial public sector & 6.5 & 29.9 & 11.3 & -12.3 & -30.3 \\
\hline Of which: DFC & 9.2 & 31.2 & 27.1 & 26.6 & 26.6 \\
\hline Claims on commercial banks & 5.1 & 0.0 & 0.0 & 0.0 & 0.0 \\
\hline Capital and other assets (net) & -6.4 & -8.1 & -3.6 & -2.3 & 3.4 \\
\hline Base Money & 203.6 & 230.0 & 255.4 & 274.3 & 287.0 \\
\hline Currency issue & 127.6 & 142.0 & 143.1 & 150.8 & 157.2 \\
\hline Reserves of commercial banks & 76.0 & 88.1 & 112.3 & 123.5 & 129.9 \\
\hline \multicolumn{6}{|l|}{ Commercial banks } \\
\hline Net foreign assets & -63.9 & -54.6 & -32.7 & 20.0 & 20.0 \\
\hline Net claims on central bank & 95.2 & 114.7 & 137.8 & 149.1 & 155.4 \\
\hline Net domestic assets & $1,099.0$ & $1,181.8$ & $1,243.6$ & $1,309.1$ & $1,363.6$ \\
\hline Credit to the public sector (net) & 33.0 & -4.9 & -13.7 & 3.9 & 26.9 \\
\hline Central government & 48.3 & 68.3 & 47.9 & 63.5 & 68.5 \\
\hline Other nonfinancial public sector & -15.3 & -73.2 & -61.6 & -59.5 & -41.5 \\
\hline Credit to the private sector & $1,107.7$ & $1,214.2$ & $1,351.6$ & $1,426.0$ & $1,477.2$ \\
\hline Other assets (net) & -41.7 & -27.4 & -94.3 & -120.8 & -140.6 \\
\hline Liabilities to the private sector & $1,130.3$ & $1,242.0$ & $1,348.7$ & $1,478.2$ & $1,539.0$ \\
\hline \multicolumn{6}{|l|}{ Monetary survey } \\
\hline Net foreign assets & 75.2 & 19.7 & 80.3 & 114.4 & 134.4 \\
\hline Medium-term foreign liabilities of $\mathrm{CBB}$ & 7.5 & 2.5 & 0.0 & 0.0 & 0.0 \\
\hline Net domestic assets & $1,158.3$ & $1,337.5$ & $1,385.9$ & $1,489.1$ & $1,536.2$ \\
\hline Public sector (net) & 98.8 & 158.9 & 132.2 & 186.2 & 196.2 \\
\hline Central government & 107.6 & 202.3 & 182.5 & 258.1 & 268.1 \\
\hline Other nonfinancial public sector & -8.8 & -43.4 & -50.2 & -71.9 & -71.9 \\
\hline Credit to private sector (by comm. banks) & $1,107.7$ & $1,214.2$ & $1,351.6$ & $1,426.0$ & $1,477.2$ \\
\hline Other items (net) & -48.2 & -35.5 & -98.0 & -123.1 & -137.2 \\
\hline Liabilities to the private sector & $1,233.5$ & $1,357.3$ & $1,466.3$ & $1,603.4$ & $1,670.6$ \\
\hline Money and quasi-money (M2) & $1,002.8$ & $1,078.0$ & $1,141.5$ & $1,250.3$ & $1,314.4$ \\
\hline Currency in circulation & 103.3 & 115.3 & 117.5 & 125.2 & 131.6 \\
\hline Deposits & 899.5 & 962.7 & $1,024.0$ & $1,125.1$ & $1,182.8$ \\
\hline Foreign currency deposits & 38.1 & 46.5 & 56.9 & 60.6 & 63.7 \\
\hline Capital and reserves of commercial banks & 192.7 & 232.7 & 267.9 & 292.6 & 292.6 \\
\hline & \multicolumn{5}{|c|}{ (In millions of U.S. dollars) } \\
\hline Net international reserves of the CBB & 73.3 & 38.4 & 56.5 & 47.2 & 57.2 \\
\hline & \multicolumn{5}{|c|}{ (In percent change, unless otherwise indicated) } \\
\hline \multicolumn{6}{|l|}{ Memorandum items: } \\
\hline Comm. bank credit to the private sector & 13.2 & 9.6 & 11.3 & 5.5 & 3.6 \\
\hline Private sector deposits in local currency & 5.8 & 7.0 & 6.4 & 9.9 & 5.1 \\
\hline Base money & 6.4 & 13.0 & 11.1 & 7.4 & 4.6 \\
\hline Money and quasi-money (M2) & 4.7 & 7.5 & 5.9 & 9.5 & 5.1 \\
\hline Required cash reserve ratio (percent) & 6.0 & 7.0 & 8.0 & 10.0 & 10.0 \\
\hline Loan deposit ratio & 118.1 & 120.3 & 125.1 & 120.3 & 118.5 \\
\hline
\end{tabular}

Sources: The Central Bank of Belize; and Fund staff estimates and projections.

1/ Assumes a net international reserve position in 2006 and 2007 consistent with closing the external financing gap. 
Table 5. Belize: Balance of Payments, 2003-11

\begin{tabular}{|c|c|c|c|c|c|c|c|c|c|}
\hline & \multirow[b]{2}{*}{2003} & \multirow[b]{2}{*}{2004} & \multirow{2}{*}{$\begin{array}{l}\text { Prel. } \\
2005\end{array}$} & \multicolumn{6}{|c|}{ Passive Proj. } \\
\hline & & & & 2006 & 2007 & 2008 & 2009 & 2010 & 2011 \\
\hline & \multicolumn{9}{|c|}{ (In millions of U.S. dollars) } \\
\hline Current account balance & -179.9 & -151.7 & -159.2 & -106.6 & -122.3 & -129.4 & -134.4 & -135.8 & -137.6 \\
\hline Trade balance & -206.8 & -173.2 & -234.3 & -189.4 & -220.2 & -242.9 & -258.6 & -271.9 & -297.2 \\
\hline Total exports, f.o.b. & 315.5 & 307.5 & 321.9 & 419.6 & 432.4 & 433.6 & 441.3 & 448.6 & 452.2 \\
\hline Of which: oil & 0.0 & 0.0 & 0.0 & 58.2 & 71.6 & 62.6 & 54.6 & 47.7 & 42.0 \\
\hline Total imports, fob & -522.3 & -480.7 & -556.2 & -609.1 & -652.6 & -676.5 & -699.9 & -720.5 & -749.4 \\
\hline Of which: fuel and energy & -66.4 & -77.3 & -97.8 & -140.7 & -156.2 & -157.8 & -157.8 & -158.2 & -160.0 \\
\hline Services & 72.7 & 88.9 & 135.2 & 156.2 & 170.1 & 188.3 & 208.1 & 230.1 & 252.9 \\
\hline Income & -86.7 & -113.3 & -111.3 & -134.8 & -135.7 & -141.0 & -152.9 & -166.0 & -168.5 \\
\hline Of which: public sector interest payments & -60.5 & -70.5 & -82.1 & -75.9 & -73.2 & -77.5 & -88.0 & -99.3 & -99.9 \\
\hline Current transfers & 40.9 & 45.9 & 51.2 & 61.5 & 63.5 & 66.2 & 69.0 & 72.0 & 75.2 \\
\hline Private (net) & 43.2 & 37.9 & 48.1 & 50.7 & 53.5 & 56.2 & 59.0 & 62.0 & 65.2 \\
\hline Official (net) & -2.3 & 8.1 & 3.1 & 10.8 & 10.0 & 10.0 & 10.0 & 10.0 & 10.0 \\
\hline Capital and financial account balance & 181.7 & 122.0 & 176.8 & 97.3 & 9.6 & 54.5 & 60.7 & 19.7 & 53.7 \\
\hline Capital transfers & 6.6 & 9.8 & 3.0 & 3.0 & 3.0 & 3.0 & 3.0 & 3.0 & 3.0 \\
\hline Public sector & 72.3 & 69.2 & 69.2 & -10.0 & -98.4 & -53.4 & -47.3 & -83.3 & -49.3 \\
\hline Disbursements 1/ & 253.1 & 213.8 & 206.4 & 61.1 & 36.2 & 21.9 & 19.6 & 17.3 & 12.3 \\
\hline Of which: Central government & 250.8 & 218.6 & 204.9 & 59.4 & 34.2 & 21.4 & 19.2 & 17.3 & 11.7 \\
\hline Amortizations & -130.6 & -169.6 & -151.4 & -71.1 & -134.6 & -75.3 & -66.9 & -100.6 & -61.6 \\
\hline Of which: Central government & -50.4 & -124.1 & -142.5 & -61.6 & -127.3 & -62.9 & -62.4 & -88.5 & -57.3 \\
\hline Privatization proceeds & -50.2 & 25.0 & 14.3 & 0.0 & 0.0 & 0.0 & 0.0 & 0.0 & 0.0 \\
\hline Private sector $2 /$ & 102.7 & 42.9 & 104.6 & 104.3 & 105.0 & 105.0 & 105.0 & 100.0 & 100.0 \\
\hline Of which: FDI and portfolio investment & -37.2 & 77.3 & 86.9 & 75.0 & 85.0 & 85.0 & 85.0 & 80.0 & 80.0 \\
\hline Errors and omissions & -31.9 & -1.6 & 0.4 & 0.0 & 0.0 & 0.0 & 0.0 & 0.0 & 0.0 \\
\hline Overall balance & -30.1 & -31.3 & 18.0 & -9.3 & -112.7 & -74.9 & -73.7 & -116.1 & -83.9 \\
\hline \multicolumn{10}{|l|}{ Financing } \\
\hline Change in reserves (- increase) & 30.1 & 31.3 & -18.0 & 9.3 & -10.0 & -10.0 & -10.0 & -10.0 & -10.0 \\
\hline Financing gap & 0.0 & 0.0 & 0.0 & 0.0 & 122.7 & 84.9 & 83.7 & 126.1 & 93.9 \\
\hline & \multicolumn{9}{|c|}{ (In percent of GDP, unless otherwise indicated) } \\
\hline Memorandum items: & & & & & & & & & \\
\hline Gross international reserves stock (US\$ millions) 3/ & 76.2 & 39.8 & 57.9 & 48.6 & 58.6 & 68.6 & 78.6 & 88.6 & 98.6 \\
\hline Current account balance & -18.2 & -14.4 & -14.3 & -8.8 & -9.6 & -9.7 & -9.6 & -9.2 & -8.9 \\
\hline Trade balance & -20.9 & -16.4 & -21.1 & -15.6 & -17.2 & -18.1 & -18.4 & -18.5 & -19.2 \\
\hline Overall balance & -3.0 & -3.0 & 1.6 & -0.8 & -8.8 & -5.6 & -5.3 & -7.9 & -5.4 \\
\hline Financing gap & 0.0 & 0.0 & 0.0 & 0.0 & 9.6 & 6.3 & 6.0 & 8.6 & 6.1 \\
\hline
\end{tabular}

Sources: Central Bank of Belize; and Fund staff estimates and projections.

$1 /$ Includes changes in assets.

2/ Detailed data on private sector flows are not available.

3/ Includes an escrow reserve account that was established for an international bond contracted in 2005. 
Table 6. Belize: Indicators of External Position and Financial Vulnerability, 2003-07

\begin{tabular}{|c|c|c|c|c|c|}
\hline & \multirow[b]{2}{*}{2003} & \multirow[b]{2}{*}{2004} & \multirow{2}{*}{$\begin{array}{c}\text { Prel. } \\
2005\end{array}$} & \multicolumn{2}{|c|}{ Passive Proj. } \\
\hline & & & & 2006 & 2007 \\
\hline \multicolumn{6}{|l|}{ Financial indicators } \\
\hline 12-month percent change in commercial bank credit to the private sector & 13.2 & 9.6 & 11.3 & 5.5 & 3.6 \\
\hline 12-month percent change in net credit to the central government & 127.7 & 88.1 & -9.8 & 41.4 & 3.9 \\
\hline Deposit rates $1 /$ & 4.9 & 5.2 & 5.5 & $\ldots$ & $\ldots$ \\
\hline Lending rates $1 /$ & 14.2 & 14.0 & 14.3 & $\ldots$ & $\ldots$ \\
\hline Regulatory capital to risk-weighted assets $2 /$ & $\ldots$ & $\ldots$ & 18.9 & $\ldots$ & $\ldots$ \\
\hline Adversely classified loans net of specific provisions to capital 2/ & $\ldots$ & $\ldots$ & 37.5 & $\ldots$ & $\ldots$ \\
\hline Adversely classified loans to total loans $2 /$ & $\ldots$ & $\ldots$ & 8.7 & $\ldots$ & $\ldots$ \\
\hline Return on Assets 2/ & $\ldots$ & $\ldots$ & 3.8 & $\ldots$ & $\ldots$ \\
\hline Return on Equity 2/ & $\ldots$ & $\ldots$ & 26.2 & $\ldots$ & $\ldots$ \\
\hline Liquid assets to total assets $2 /$ & $\ldots$ & $\ldots$ & 19.5 & $\ldots$ & $\ldots$ \\
\hline Liquid assets to short term liabilities $2 /$ & $\ldots$ & $\ldots$ & 47.4 & $\ldots$ & $\ldots$ \\
\hline \multicolumn{6}{|l|}{ Exchange rate indicators } \\
\hline Real effective exchange rate (+ appreciation; end of period) & -2.5 & -2.4 & -1.3 & $\ldots$ & $\ldots$ \\
\hline \multicolumn{6}{|l|}{ Trade indicators } \\
\hline Exports of goods and services (percent change, U.S. dollars basis) & 8.7 & 2.9 & 13.3 & 21.7 & 5.0 \\
\hline Imports of goods and services (percent change, U.S. dollars basis) & 5.6 & -5.2 & 13.8 & 9.5 & 6.9 \\
\hline Terms of trade (deterioration -) & -2.0 & -2.5 & -5.9 & -3.7 & -1.3 \\
\hline \multicolumn{6}{|l|}{ Debt indicators } \\
\hline Total external public debt in percent of GDP & 96.7 & 91.2 & 91.2 & 83.1 & 80.5 \\
\hline Central government debt & 72.8 & 76.8 & 78.9 & 78.8 & 77.0 \\
\hline Public and publicly guaranteed debt & 23.8 & 14.4 & 12.3 & 4.2 & 3.5 \\
\hline Total external public debt in percent of exports of goods and services & 180.9 & 177.3 & 164.8 & 135.1 & 131.1 \\
\hline Central government debt & 136.3 & 149.3 & 142.5 & 128.2 & 125.4 \\
\hline Public and publicly guaranteed debt & 44.6 & 28.0 & 22.3 & 6.9 & 5.7 \\
\hline Public debt service in percent of GDP $3 /$ & 19.3 & 22.8 & 21.0 & 12.4 & 16.5 \\
\hline Amortization & 13.2 & 16.1 & 13.6 & 5.8 & 10.5 \\
\hline Interest & 6.1 & 6.7 & 7.4 & 6.5 & 6.0 \\
\hline Public debt service in percent of exports of goods and services & 36.2 & 44.2 & 38.0 & 20.1 & 26.8 \\
\hline Amortization & 24.8 & 31.2 & 24.6 & 9.5 & 17.1 \\
\hline Interest & 11.5 & 13.0 & 13.4 & 10.6 & 9.7 \\
\hline Public debt service in percent of current government revenue $4 /$ & 93.3 & 108.3 & 92.4 & 52.4 & 65.4 \\
\hline Amortization & 63.8 & 76.5 & 59.9 & 24.7 & 41.7 \\
\hline Interest & 29.5 & 31.8 & 32.5 & 27.7 & 23.7 \\
\hline \multicolumn{6}{|l|}{ International reserves indicators } \\
\hline Gross official reserves (US\$ million) & 76.2 & 39.8 & 57.9 & 48.6 & 58.6 \\
\hline In months of imports & 1.4 & 0.8 & 1.0 & 0.7 & 0.8 \\
\hline In percent of amortizations due in the following year & 46.9 & 26.3 & 81.4 & 36.1 & 77.8 \\
\hline In percent of M2 & 15.2 & 7.4 & 10.1 & 7.8 & 8.9 \\
\hline Usable gross official reserves (US\$ million) & 74.2 & 38.0 & 28.9 & 28.5 & 38.5 \\
\hline In months of imports & 1.3 & 0.7 & 0.5 & 0.4 & 0.6 \\
\hline In percent of amortizations due in the following year & 45.6 & 25.1 & 40.6 & 21.2 & 51.1 \\
\hline In percent of M2 & 14.8 & 7.1 & 5.1 & 4.6 & 5.9 \\
\hline \multicolumn{6}{|l|}{ Balance of payments } \\
\hline Current account balance (in percent of GDP) & -18.2 & -14.4 & -14.3 & -8.8 & -9.6 \\
\hline Capital and financial account balance (in percent of GDP) & 15.2 & 11.4 & 16.0 & 8.0 & 0.8 \\
\hline Public sector & 7.9 & 7.4 & 6.5 & -0.6 & -7.5 \\
\hline Private sector $5 /$ & 7.3 & 4.0 & 9.5 & 8.6 & 8.2 \\
\hline
\end{tabular}

Sources: Central Bank of Belize, Ministry of Finance; and Fund staff estimates.

1/ End of period weighted average.

2/ Domestic commercial banks.

$3 /$ Includes debt service on DFC debt secured by mortgage receivable securitization.

4/ Only central government debt service.

$5 /$ Including errors and omissions. 
Table 7. Belize: Medium-Term Outlook, 2005-15

(Passive Scenario)

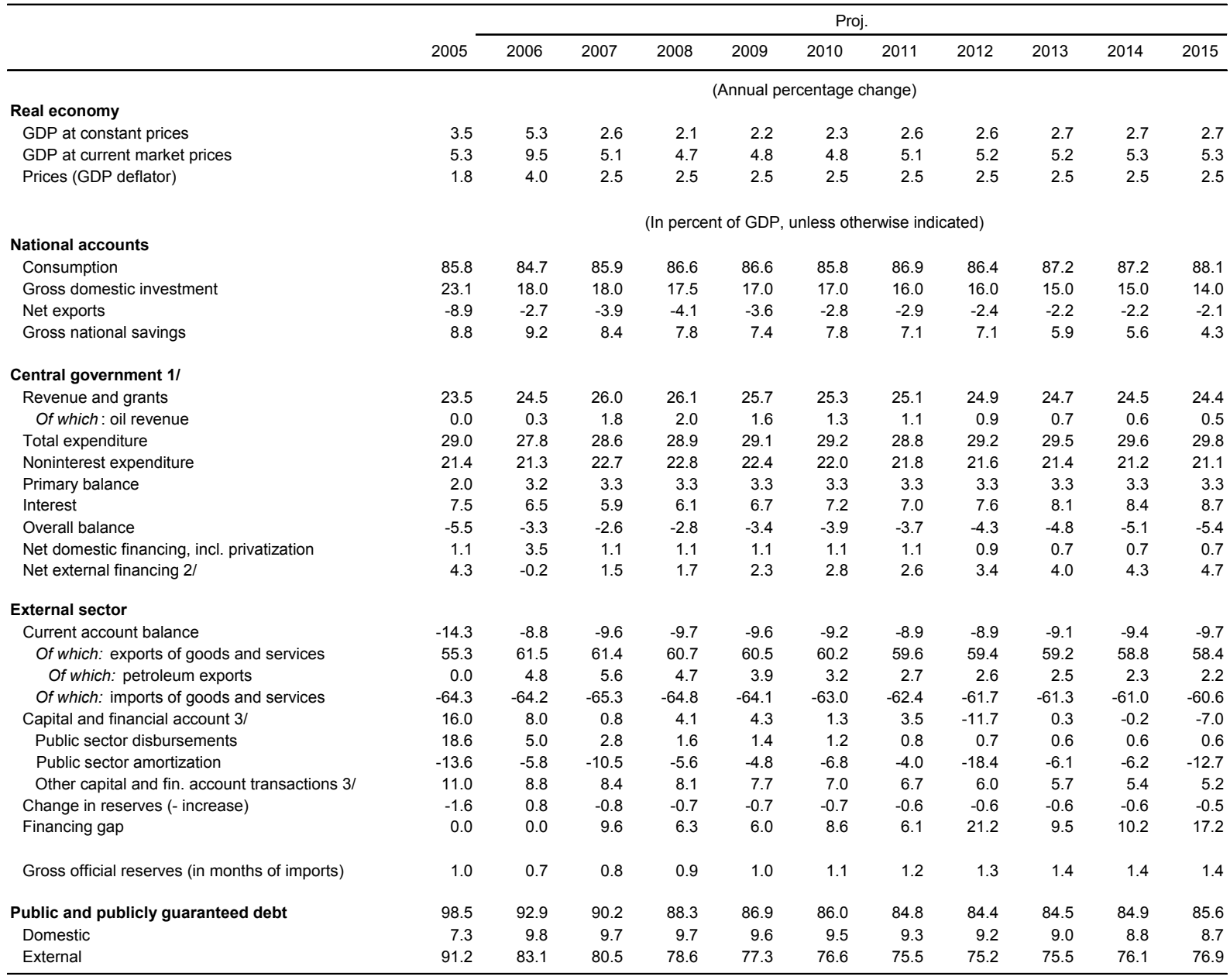

Source: Fund staff projections.

1/ Fiscal projections are on a calendar year basis.

2/ Includes financing gap.

$3 /$ Includes errors and omissions. 
Table 8. Belize: Public and Publicly Guaranteed Debt Simulations, 2005-15 1/

(Passive Scenario)

\begin{tabular}{|c|c|c|c|c|c|c|c|c|c|c|c|}
\hline & \multirow{2}{*}{$\begin{array}{c}\text { Prel. } \\
2005\end{array}$} & \multicolumn{10}{|c|}{ Proj. } \\
\hline & & 2006 & 2007 & 2008 & 2009 & 2010 & 2011 & 2012 & 2013 & 2014 & 2015 \\
\hline & \multicolumn{11}{|c|}{ (In millions of U.S. dollars) } \\
\hline \multicolumn{12}{|l|}{ 1. Public and publicly guaranteed debt } \\
\hline Total & $1,094.5$ & $1,130.2$ & $1,154.2$ & $1,181.8$ & $1,218.8$ & $1,265.3$ & $1,311.3$ & $1,372.3$ & $1,446.3$ & $1,529.7$ & $1,623.6$ \\
\hline Domestic & 81.4 & 119.2 & 124.2 & 129.2 & 134.2 & 139.2 & 144.2 & 149.2 & 154.2 & 159.2 & 164.2 \\
\hline External & $1,013.1$ & $1,011.0$ & $1,029.9$ & $1,052.6$ & $1,084.6$ & $1,126.1$ & $1,167.0$ & $1,223.0$ & $1,292.1$ & $1,370.4$ & $1,459.4$ \\
\hline Multilateral & 228.6 & 233.1 & 229.7 & 222.7 & 214.7 & 206.3 & 195.0 & 185.2 & 174.3 & 163.5 & 153.3 \\
\hline Bilateral and export credit & 167.4 & 195.0 & 202.4 & 202.0 & 201.0 & 199.0 & 194.5 & 190.4 & 186.3 & 181.7 & 176.9 \\
\hline Commercial, including pararstatal & 617.1 & 582.9 & 597.8 & 627.9 & 668.8 & 720.8 & 777.5 & 847.5 & 931.6 & $1,025.2$ & $1,129.2$ \\
\hline \multicolumn{12}{|l|}{ In percent of GDP } \\
\hline Total & 98.5 & 92.9 & 90.2 & 88.3 & 86.9 & 86.0 & 84.8 & 84.4 & 84.5 & 84.9 & 85.6 \\
\hline Domestic & 7.3 & 9.8 & 9.7 & 9.7 & 9.6 & 9.5 & 9.3 & 9.2 & 9.0 & 8.8 & 8.7 \\
\hline External & 91.2 & 83.1 & 80.5 & 78.6 & 77.3 & 76.6 & 75.5 & 75.2 & 75.5 & 76.1 & 76.9 \\
\hline Multilateral & 20.6 & 19.2 & 18.0 & 16.6 & 15.3 & 14.0 & 12.6 & 11.4 & 10.2 & 9.1 & 8.1 \\
\hline Bilateral and export credit & 15.1 & 16.0 & 15.8 & 15.1 & 14.3 & 13.5 & 12.6 & 11.7 & 10.9 & 10.1 & 9.3 \\
\hline Commercial, including parastatal & 55.5 & 47.9 & 46.7 & 46.9 & 47.7 & 49.0 & 50.3 & 52.1 & 54.4 & 56.9 & 59.5 \\
\hline 2. Flow of funds & \multicolumn{11}{|c|}{ (In percent of GDP, unless otherwise stated) } \\
\hline \multicolumn{12}{|l|}{ 2.1. Sources of funds } \\
\hline Primary balance & 2.0 & 3.2 & 3.3 & 3.3 & 3.3 & 3.3 & 3.3 & 3.3 & 3.3 & 3.3 & 3.3 \\
\hline Privatization proceeds $2 /$ & 2.3 & 0.4 & 0.7 & 0.7 & 0.7 & 0.7 & 0.7 & 0.6 & 0.5 & 0.4 & 0.4 \\
\hline Identified disbursements & 17.3 & 8.0 & 3.1 & 2.0 & 1.7 & 1.5 & 1.1 & 1.0 & 0.9 & 0.9 & 0.8 \\
\hline Multilateral & & 1.2 & 0.7 & 0.5 & 0.4 & 0.3 & 0.1 & 0.1 & 0.0 & 0.0 & 0.0 \\
\hline Bilateral and export credit & & 3.5 & 1.8 & 1.0 & 0.9 & 0.8 & 0.6 & 0.6 & 0.6 & 0.6 & 0.5 \\
\hline Commercial & & 3.3 & 0.5 & 0.5 & 0.4 & 0.4 & 0.3 & 0.3 & 0.3 & 0.3 & 0.3 \\
\hline Domestic (net) & -1.2 & 3.1 & 0.4 & 0.4 & 0.4 & 0.3 & 0.3 & 0.3 & 0.3 & 0.3 & 0.3 \\
\hline External & & 0.2 & 0.1 & 0.1 & 0.1 & 0.0 & 0.0 & 0.0 & 0.0 & 0.0 & 0.0 \\
\hline \multicolumn{12}{|l|}{ 2.2. Use of funds } \\
\hline Debt service & 21.2 & 11.6 & 15.8 & 10.8 & 11.1 & 13.2 & 10.7 & 25.8 & 14.0 & 14.5 & 21.3 \\
\hline Interest payments & 7.6 & 6.5 & 5.9 & 6.1 & 6.7 & 7.2 & 7.0 & 7.6 & 8.1 & 8.4 & 8.7 \\
\hline Domestic & 0.7 & 0.9 & 0.8 & 0.8 & 0.8 & 0.7 & 0.7 & 0.7 & 0.7 & 0.7 & 0.7 \\
\hline External & 6.9 & 5.6 & 5.1 & 5.3 & 5.9 & 6.5 & 6.3 & 6.9 & 7.4 & 7.7 & 8.0 \\
\hline Principal repayments & 13.6 & 5.1 & 10.0 & 4.7 & 4.4 & 6.0 & 3.7 & 18.2 & 5.9 & 6.1 & 12.6 \\
\hline Multilateral & & 0.8 & 1.0 & 1.0 & 1.0 & 0.9 & 0.8 & 0.7 & 0.7 & 0.6 & 0.6 \\
\hline Bilateral and export credit & & 1.2 & 1.3 & 1.0 & 0.9 & 0.9 & 0.9 & 0.9 & 0.8 & 0.8 & 0.8 \\
\hline Commercial, including pararstatal & & 3.0 & 7.7 & 2.6 & 2.5 & 4.2 & 1.9 & 16.6 & 4.5 & 4.7 & 11.3 \\
\hline 2.3. Financing gap & 0.0 & 0.0 & 8.8 & 4.8 & 5.4 & 7.7 & 5.6 & 20.9 & 9.4 & 9.9 & 16.8 \\
\hline Five-year average & & & & & & 5.9 & & & & & 12.5 \\
\hline \multicolumn{12}{|l|}{ Assumptions } \\
\hline Nominal GDP (US\$ millions) & $1,110.9$ & $1,216.8$ & $1,279.1$ & $1,339.1$ & $1,402.8$ & $1,470.5$ & $1,546.0$ & $1,626.2$ & $1,711.3$ & $1,801.6$ & $1,897.3$ \\
\hline Nominal GDP growth rate (percent) & 5.3 & 9.5 & 5.1 & 4.7 & 4.8 & 4.8 & 5.1 & 5.2 & 5.2 & 5.3 & 5.3 \\
\hline Real GDP growth rate (percent) & 3.5 & 5.3 & 2.6 & 2.1 & 2.2 & 2.3 & 2.6 & 2.6 & 2.7 & 2.7 & 2.7 \\
\hline Annual inflation (deflator, in percent) & 1.8 & 4.0 & 2.5 & 2.5 & 2.5 & 2.5 & 2.5 & 2.5 & 2.5 & 2.5 & 2.5 \\
\hline Assumed domestic borrowing rate (percent) & & 8.0 & 8.0 & 8.0 & 8.0 & 8.0 & 8.0 & 8.0 & 8.0 & 8.0 & 8.0 \\
\hline Nominal external commercial borrowing rate (percent) & & 14.0 & 14.0 & 14.0 & 14.1 & 14.2 & 14.2 & 14.3 & 14.3 & 14.4 & 14.4 \\
\hline Assumed 5-year U.S. T-Bond (percent) & & 5.0 & 5.0 & 5.0 & 5.1 & 5.2 & 5.2 & 5.3 & 5.3 & 5.4 & 5.4 \\
\hline Spread over 5-year U.S. T-Bond (percent) & & 9.0 & 9.0 & 9.0 & 9.0 & 9.0 & 9.0 & 9.0 & 9.0 & 9.0 & 9.0 \\
\hline Nominal external bilateral borrowing rate (percent) & & 6.4 & 6.5 & 6.5 & 6.5 & 6.5 & 6.5 & 6.1 & 6.1 & 6.1 & 6.1 \\
\hline Six-month LIBOR rate (percent) $3 /$ & & 5.4 & 5.5 & 5.5 & 5.5 & 5.5 & 5.5 & 5.1 & 5.1 & 5.1 & 5.1 \\
\hline Spread over LIBOR rate (percent) & & 1.0 & 1.0 & 1.0 & 1.0 & 1.0 & 1.0 & 1.0 & 1.0 & 1.0 & 1.0 \\
\hline \multicolumn{12}{|l|}{ Memorandum items: } \\
\hline Overall balance (calendar year, percent of GDP) & -5.5 & -3.3 & -2.6 & -2.8 & -3.4 & -3.9 & -3.7 & -4.3 & -4.8 & -5.1 & -5.4 \\
\hline Overall balance (fiscal year, percent of GDP) & -3.3 & -3.2 & -2.4 & -2.9 & -3.5 & -3.8 & -3.9 & -4.5 & -4.9 & -5.1 & -5.4 \\
\hline Primary balance (fiscal year, percent of GDP) & 3.0 & 3.4 & 3.3 & 3.3 & 3.3 & 3.3 & 3.3 & 3.3 & 3.3 & 3.3 & 3.3 \\
\hline Effective nominal interest rate (percent) & 7.9 & 7.3 & 6.6 & 7.0 & 7.9 & 8.7 & 8.6 & 9.5 & 10.1 & 10.5 & 10.7 \\
\hline
\end{tabular}

Sources: Belizean authorities; and Fund staff estimates and projections.

$1 /$ The total debt stock covers the central government and quasi-fiscal entities. The quasi-fiscal entities (other than the DFC) are assumed to roll over external debt and cover interest payments from their own resources, while the central government will assume one-third of the DFC's external amortization payments.

2/ Includes assets recovery from the Development Finance Corporation.

3/ September 2006 World Economic Outlook assumptions. 
Table 9. Belize: Medium-Term Outlook, 2005-15 (Active Scenario)

\begin{tabular}{|c|c|c|c|c|c|c|c|c|c|c|c|}
\hline & \multicolumn{11}{|c|}{ Proj. } \\
\hline & 2005 & 2006 & 2007 & 2008 & 2009 & 2010 & 2011 & 2012 & 2013 & 2014 & 2015 \\
\hline & \multicolumn{11}{|c|}{ (Annual percentage change) } \\
\hline \multicolumn{12}{|l|}{ Real economy } \\
\hline GDP at constant prices & 3.5 & 5.3 & 3.5 & 3.3 & 3.4 & 3.4 & 3.7 & 3.8 & 3.9 & 3.9 & 3.9 \\
\hline GDP at current market prices & 5.3 & 9.5 & 6.1 & 5.9 & 5.9 & 6.0 & 6.3 & 6.4 & 6.5 & 6.5 & 6.5 \\
\hline Prices (GDP deflator) & 1.8 & 4.0 & 2.5 & 2.5 & 2.5 & 2.5 & 2.5 & 2.5 & 2.5 & 2.5 & 2.5 \\
\hline & \multicolumn{11}{|c|}{ (In percent of GDP, unless otherwise indicated) } \\
\hline \multicolumn{12}{|l|}{ National accounts } \\
\hline Consumption & 85.8 & 84.7 & 87.6 & 86.6 & 86.4 & 86.5 & 86.2 & 85.4 & 84.9 & 84.2 & 83.7 \\
\hline Gross domestic investment & 23.1 & 18.0 & 18.0 & 18.0 & 18.0 & 17.0 & 17.0 & 17.0 & 17.0 & 17.0 & 17.0 \\
\hline Net exports & -8.9 & -2.7 & -5.6 & -4.6 & -4.4 & -3.5 & -3.2 & -2.4 & -1.9 & -1.2 & -0.7 \\
\hline Gross national savings & 8.8 & 9.2 & 6.9 & 8.1 & 8.1 & 7.9 & 8.9 & 9.8 & 11.2 & 12.2 & 13.2 \\
\hline \multicolumn{12}{|l|}{ Central government $1 /$} \\
\hline Revenue and grants & 23.5 & 24.6 & 26.0 & 26.3 & 26.1 & 25.7 & 25.4 & 25.2 & 25.0 & 24.8 & 24.7 \\
\hline Of which: oil revenue & 0.0 & 0.3 & 1.8 & 1.9 & 1.6 & 1.2 & 1.0 & 0.8 & 0.7 & 0.5 & 0.4 \\
\hline Total expenditure & 29.0 & 27.6 & 27.0 & 27.0 & 27.2 & 27.3 & 26.5 & 26.4 & 25.4 & 24.8 & 24.2 \\
\hline Noninterest expenditure & 21.4 & 21.0 & 21.5 & 21.7 & 21.6 & 21.5 & 21.3 & 21.2 & 21.1 & 20.8 & 20.7 \\
\hline Primary balance & 2.0 & 3.5 & 4.5 & 4.5 & 4.4 & 4.2 & 4.1 & 4.0 & 4.0 & 4.0 & 4.0 \\
\hline Interest & 7.5 & 6.5 & 5.5 & 5.3 & 5.6 & 5.8 & 5.2 & 5.2 & 4.4 & 4.0 & 3.5 \\
\hline Overall balance & -5.5 & -3.0 & -1.0 & -0.8 & -1.2 & -1.6 & -1.1 & -1.1 & -0.4 & 0.0 & 0.5 \\
\hline Net domestic financing, incl. privatization & 1.1 & 2.4 & -3.3 & -0.4 & 0.4 & 1.0 & 1.0 & 0.9 & 0.7 & 0.7 & 0.7 \\
\hline Net external financing $2 /$ & 4.3 & 0.6 & 4.3 & 1.1 & 0.8 & 0.6 & 0.1 & 0.3 & -0.3 & -0.7 & -1.1 \\
\hline \multicolumn{12}{|l|}{ External sector } \\
\hline Current account balance & -14.3 & -8.8 & -11.1 & -9.9 & -9.9 & -9.1 & -8.1 & -7.2 & -5.8 & -4.8 & -3.8 \\
\hline Of which: exports of goods and services & 55.3 & 61.5 & 61.6 & 61.1 & 61.0 & 60.9 & 60.6 & 60.8 & 61.0 & 60.9 & 61.0 \\
\hline Of which: petroleum exports & 0.0 & 4.8 & 5.5 & 4.6 & 3.8 & 3.1 & 2.6 & 2.4 & 2.3 & 2.1 & 2.0 \\
\hline Of which: imports of goods and services & -64.3 & -64.2 & -67.2 & -65.6 & -65.4 & -64.4 & -63.9 & -63.2 & -62.8 & -62.1 & -61.7 \\
\hline Capital and financial account $3 /$ & 16.0 & 8.8 & 6.2 & 5.9 & 6.6 & 3.7 & 5.7 & -2.1 & 6.1 & 5.7 & 1.1 \\
\hline Public sector disbursements & 18.6 & 5.8 & 6.9 & 2.5 & 2.2 & 1.9 & 1.5 & 1.4 & 1.3 & 1.2 & 1.1 \\
\hline Public sector amortization & -13.6 & -6.1 & -10.6 & -5.7 & -4.8 & -6.9 & -4.3 & -11.4 & -2.9 & -2.7 & -7.1 \\
\hline Other capital and fin. account transactions 3 / & 11.0 & 9.1 & 9.9 & 9.0 & 9.2 & 8.7 & 8.5 & 7.9 & 7.7 & 7.3 & 7.1 \\
\hline Change in reserves (- increase) & -1.6 & -0.1 & -1.9 & -1.8 & -1.7 & -1.6 & -1.5 & -1.4 & -1.4 & -1.3 & -1.2 \\
\hline Financing gap & 0.0 & 0.0 & 6.9 & 5.8 & 5.0 & 7.0 & 3.9 & 10.7 & 1.0 & 0.3 & 3.9 \\
\hline Gross official reserves (in months of imports) & 1.0 & 0.9 & 1.2 & 1.5 & 1.7 & 1.9 & 2.1 & 2.3 & 2.4 & 2.5 & 2.6 \\
\hline Public and publicly guaranteed debt & 98.5 & 92.6 & 87.5 & 82.7 & 78.5 & 74.9 & 70.8 & 67.1 & 63.0 & 58.7 & 54.2 \\
\hline Domestic & 7.3 & 8.7 & 4.2 & 2.8 & 2.3 & 2.4 & 2.6 & 2.7 & 2.8 & 2.9 & 3.0 \\
\hline External & 91.2 & 83.9 & 83.4 & 79.9 & 76.2 & 72.5 & 68.3 & 64.4 & 60.2 & 55.8 & 51.3 \\
\hline
\end{tabular}

Source: Fund staff projections.

1/ Fiscal projections are on a calendar year basis.

$2 /$ Includes financing gap.

$3 /$ Includes errors and omissions. 
Table 10. Belize: Public and Publicly Guaranteed Debt Simulations, 2005-15 1/ (Active Scenario)

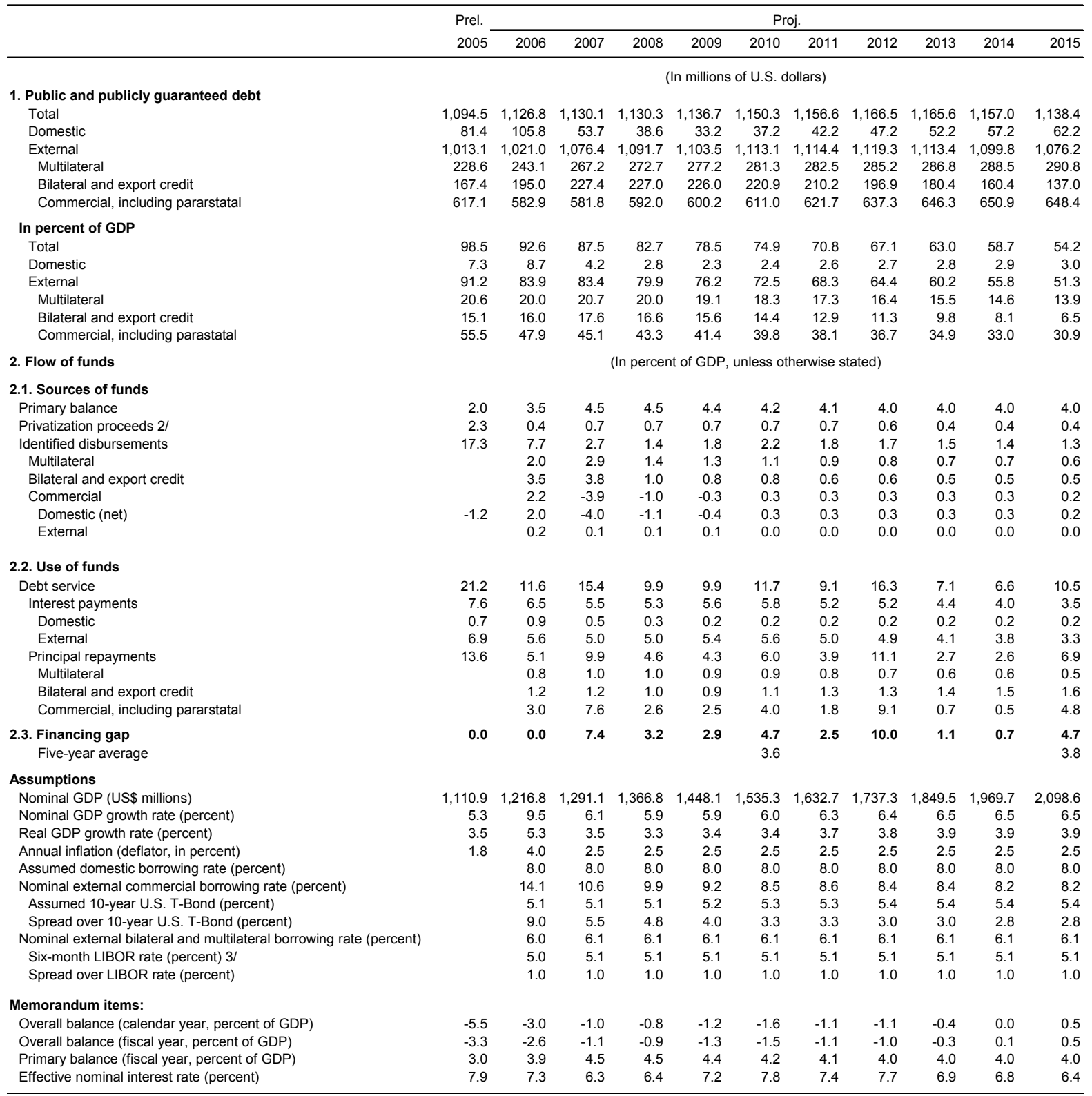

Sources: Belizean authorities; and Fund staff estimates and projections.

1/ The total debt stock covers the central government and quasi-fiscal entities. The quasi-fiscal entities (other than the DFC) are assumed to roll over external debt and cover interest payments from their own resources, while the central government will assume one-third of the DFC's external amortization payments.

$2 /$ Includes assets recovery from the Development Finance Corporation.

3/ September 2006 World Economic Outlook assumptions. 


\section{Appendix I. Belize-Fund Relations}

(As of August 31, 2006)

$\begin{array}{llcc}\text { I. Membership Status: } & \text { Joined March 16, 1982 } & \text { Article VIII } \\ \text { II. } & \text { General Resources Account: } & \text { SDR Million } & \text { \% Quota } \\ & \text { Quota } & 18.80 & 10.00 \\ & \text { Fund holdings of currency } & 14.56 & 77.46 \\ & \text { Reserve position } & 4.24 & 22.55 \\ \text { III. } & \text { SDR Department: } & \text { SDR Million } & \text { \% Allocation } \\ & \text { Holdings } & 1.88 & \text { N/A }\end{array}$

IV. Outstanding Purchases and Loans: None

V. Latest Financial Arrangements:

$\begin{array}{ccccc}\text { Type } & \begin{array}{c}\text { Approval } \\ \text { Date }\end{array} & \begin{array}{c}\text { Expiration } \\ \text { Date }\end{array} & \begin{array}{c}\text { Amount } \\ \text { Approved } \\ \text { (SDR Million) }\end{array} & \begin{array}{c}\text { Amount } \\ \text { Drawn } \\ \text { (SDR }\end{array} \\ \text { Stand-By } & \text { Dec. 3, 1984 } & \text { May 31, 1986 } & 7.13 & \frac{\underline{\text { Million) }}}{7.13}\end{array}$

VI. Projected Payments to the Fund: None

VII. Implementation of HIPC Initiative: Not Applicable

VIII. Implementation of MDRI Assistance: Not Applicable

\section{B. Nonfinancial Relations}

\section{Exchange Rate}

Since 1976, the Belize dollar has been pegged to the U.S. dollar, the intervention currency, at the rate of BZ\$2 per U.S. dollar. Belize does not maintain exchange restrictions or multiple currency practices. The central bank has not engaged in selective sales or rationing of foreign exchange to the private sector since 2004, and there does not appear to be an unsatisfied foreign exchange demand from commercial banks. 


\section{Last Article IV Consultation}

The last Article IV consultation was concluded by the Executive Board on September 19, 2005; the relevant documents were published as IMF Country Report Nos. 05/352 and $05 / 353$. Belize is on the standard 12-month consultation cycle.

\section{Recent Technical Assistance}

In recent years, Belize has benefited from technical assistance in the areas of tax policy, tax administration, economic statistics, bank supervision and macroeconomic programming, both from IMF headquarters and the Caribbean Regional Technical Assistance Center (CARTAC).

- In January 2002 and July 2006, CARTAC experts visited Belize to advise the Central Statistical Office on improving National Income Accounting.

- During early 2004-June 2005, a long-term consultant from IMF's Monetary and Financial Systems Department (MFD) assisted the Central Bank of Belize in banking supervision.

- In March 2005, a joint mission from the IMF's Legal Department and MFD visited Belize to advise the authorities on strengthening their regime to combat money laundering and the financing of terrorism (AML/CFT).

- In October 2005, a mission from the IMF's Statistics Department (STA) visited Belize to assist the central bank in strengthening monetary and financial statistics.

- During 2005 and 2006, CARTAC provided extensive assistance through frequent expert visits to help design and implement a General Sales Tax.

- During 2006, experts from CARTAC conducted macroeconomic programming workshops in Belize.

Further IMF technical assistance is planned in 2006 and early 2007. CARTAC experts will continue to assist the authorities in the post-implementation period of the GST, while a headquarters-based mission from the Fiscal Affairs Department is expected to provide assistance in strengthening tax administration. A multisector mission on economic statistics from STA is scheduled for early 2007, and the authorities have requested assistance from the Monetary and Capital Markets Department in developing monetary policy instruments. 


\section{Appendix II. Belize-Relations with the World Bank Group}

(As of August 31, 2006)

\section{Projects}

A five year Country Assistance Strategy was completed for Belize in August 2000 (Report No. 20708-BEL), which identified only modest project assistance. The World Bank currently has no active projects in Belize.

\section{Financial Relations}

\section{IBRD/IDA Operations}

\section{Loans/Credits/Grants Summary in US\$ Equivalent}

\begin{tabular}{lrrrr} 
& \multicolumn{1}{c}{ IBRD } & IDA Credits & IDA Grants & Total \\
\hline Original Principal & $86,200,000$ & 0 & 0 & $86,200,000$ \\
Cancellations & $5,703,328$ & 0 & 0 & $5,703,328$ \\
Disbursed & $80,496,672$ & 0 & 0 & $80,496,672$ \\
Undisbursed & 0 & 0 & 0 & 0 \\
Repaid & $48,180,269$ & 0 & 0 & $48,180,269$ \\
Due & $32,316,403$ & 0 & 0 & $32,316,403$ \\
Exchange Adjustment & $-1,089,192$ & 0 & 0 & $-1,089,192$ \\
Borrower Obligation & $31,227,211$ & 0 & 0 & $31,227,211$ \\
\hline
\end{tabular}

Gross Disbursements and Debt Service During Fiscal Year (July-June)

(In millions of U.S. dollars)

\begin{tabular}{lrrrrrrr} 
& $\mathbf{2 0 0 1}$ & $\mathbf{2 0 0 2}$ & $\mathbf{2 0 0 3}$ & $\mathbf{2 0 0 4}$ & $\mathbf{2 0 0 5}$ & $\mathbf{2 0 0 6}$ & $\begin{array}{r}\mathbf{2 0 0 7} \\
\text { Est. }\end{array}$ \\
\hline Disbursements & 4.7 & 5.5 & 4.3 & 1.6 & 0.7 & 0.7 & 0 \\
Repayments & 3.3 & 3.4 & 4.8 & 4.8 & 4.5 & 4.5 & 4.9 \\
Net & 1.3 & 2.1 & -0.5 & -3.2 & -3.8 & -3.8 & -4.9 \\
Interest and Fees & 1.8 & 3.1 & 2.6 & 2.0 & 1.7 & 1.7 & 1.8 \\
\hline
\end{tabular}


Appendix III. Belize-Relations with the Inter-American Development Bank

(As of August 31, 2006)

\author{
I. Current Portfolio \\ (In millions of U.S. dollars)
}

\begin{tabular}{lcc}
\multicolumn{1}{c}{ Loan } & Approved & Undisbursed \\
Land Administration II & 7.0 & 3.0 \\
Health Sector Reform & 9.8 & 6.3 \\
Total & $\mathbf{1 6 . 8}$ & $\mathbf{9 . 3}$
\end{tabular}

\title{
II. Loan Transactions
}

\begin{tabular}{lrrrrrrr} 
& & & & & & & Proj. \\
& $\mathbf{2 0 0 0}$ & $\mathbf{2 0 0 1}$ & $\mathbf{2 0 0 2}$ & $\mathbf{2 0 0 3}$ & $\mathbf{2 0 0 4}$ & $\mathbf{2 0 0 5}$ & $\mathbf{2 0 0 6}$ \\
\hline Net Flows & $\mathbf{1 0 . 3}$ & $\mathbf{1 6 . 3}$ & $\mathbf{1 1 . 8}$ & $\mathbf{1 2 . 2}$ & $\mathbf{3 . 3}$ & $\mathbf{- 3 . 1}$ & $\mathbf{- 0 . 2}$ \\
Gross disbursements & 11.1 & 18.3 & 14.3 & 15.8 & 8.1 & 2.9 & 7.1 \\
Amortization & 0.0 & 0.0 & 0.0 & 0.5 & 1.6 & 2.5 & 3.8 \\
Interest and charges & 0.8 & 2.0 & 2.0 & 3.1 & 3.2 & 3.5 & 3.5 \\
\hline
\end{tabular}

\section{Economic and Sector Work}

The 2004-08 IDB-Country Strategy with Belize, approved in September 2004, aims at assisting the country in its transition towards private sector-led growth. Accordingly, the Bank's strategy focuses on the major objective of "supporting private sector-led growth". This is done by financing interventions oriented to (i) improving the public sector's institutional capacity to foster an enabling environment for private sector development; and (ii) supporting private sector capacity-building and specific initiatives. Sustainable economic growth and poverty reduction are considered the overarching goals of the Strategy.

From 1998 to 2001, the Bank approved seven operations for a total of US\$84.1 million. No loans have been approved since 2001 due to the unsustainable level of Belize's external debt. The Bank's 2006 pipeline has a \$25 million Policy-based Loan to support macroeconomic and public financial sector reforms. In the absence of lending operations, the Bank has been active in supporting Belize through Technical Cooperation (TC) projects. Targeting the areas of particular concern in Belize, the Bank approved two TC operations in 2006 to strengthen the national response to HIV/AIDS and to strengthen the Government's capacity to combat human trafficking. The pipeline for 2006 has a project for strengthening results-based management in the public sector under the Bank's PRODEV initiative that aims to improve the quality of public investment. In addition, the pipeline of the Multilateral Investment Fund (MIF) has a project for developing a mentoring model for young people interested in becoming entrepreneurs. 
The Bank's nonfinancial products include a Financial Intermediation Study that explores the options for an alternative mechanism for development financing, as part of the dissolution process for the Development Finance Corporation (DFC). The Bank has also finalized Belize Fiscal Study and Public Expenditure Review with recommendations on public finance reforms. Finally, the Bank is contracting with the World Economic Forum (WEF) to develop competitiveness indicators for Belize. 


\section{Appendix IV. Belize-Relations with the Caribbean Development Bank (CDB)}

(As of August 31, 2006)

\section{Current Portfolio}

(In millions of U.S. dollars)

Loan

Disaster Preparedness

Fifth Line of Credit

Second Water and Sewerage Project

Rural Development

Health Sector Reform Program

Enhancement of Technical and Vocational Education

Southern Highway Rehabilitation

Social Investment Fund

Belize Cogeneration Energy Limited (Belcogen)

Total
Approved

9.2

7.3

13.8

3.4

5.6

16.1

1.8

7.1

8.3

72.6
Undisbursed

3.1

0.0

1.7

2.2

4.2

3.1

0.6

6.9

8.3

30.1

\section{Loan Transactions}

\begin{tabular}{|c|c|c|c|c|c|c|c|}
\hline & 2000 & 2001 & 2002 & 2003 & 2004 & 2005 & $\begin{array}{r}\text { August } \\
2006\end{array}$ \\
\hline Net flows & 6.2 & 6.1 & 3.7 & 6.1 & 9.3 & 4.0 & -0.7 \\
\hline Gross disbursements & 9.0 & 9.3 & 7.6 & 9.5 & 13.5 & 9.4 & 2.9 \\
\hline Amortizations & 2.8 & 3.2 & 3.9 & 3.4 & 4.2 & 5.4 & 3.6 \\
\hline Interest and charges & 3.2 & 3.9 & 3.6 & 3.6 & 3.9 & 4.5 & 3.2 \\
\hline
\end{tabular}

\section{Economic and Sector Work}

Much of the CDB's country and sector work in Belize since 2003 has focused on helping the authorities to address significant macroeconomic and fiscal imbalances, and sustainability issues in the operations of the Development Finance Corporation. This has resulted in a slower rate of loan approvals. A private sector loan to Belcogen was approved in 2005 and appraisal work is currently ongoing on another private sector agriculture project.

Consideration of a request for loan funding for a public sector road infrastructure project proposals has been delayed in light of the current macro-economic situation. Activity levels on CDB's main direct poverty reduction program, the Basic Needs Trust Fund, has been maintained.

The Belize authorities have been making significant effort to address the difficult fiscal and debt consequences that have resulted from the expansionary policies of recent years. Currently, the CDB is preparing a Country Strategy Paper for Belize. One of the interventions likely over the short term is a Policy-based Loan to assist Belize in making the necessary adjustments to correct macro-economic imbalances. 


\section{Appendix V. Belize-Statistical Issues}

In general, the coverage and timeliness of statistical information permit adequate monitoring of economic developments. However, there are shortcomings in national accounts, prices, external trade and debt, government finance, and labor statistics. The Central Bank of Belize publishes, in irregular intervals, a quarterly bulletin covering developments in the real, fiscal, monetary, and external sectors, as well as an annual report and a statistical digest. In September 2006, Belize began participating in IMF's General Data Dissemination System $(G D D S)$.

\section{Real sector}

National accounts at constant and current prices are produced on a quarterly and annual basis. The base year for the compilation of national accounts has moved from 1984 to 2000, with consequent quality improvement of estimates at constant and current prices. Economic transactions arising from the recent discovery of oil should be properly reflected in the national accounts and other economic statistics, since they may be substantial. The CPI market basket is based on a household expenditure survey conducted from June 1990 through March 1991 and needs to be updated. Also, the CPI is calculated only four times a year (February, May, August, and November), with a lag of about three months. Labor market statistics are scant and available at irregular intervals.

\section{Fiscal accounts}

Classification of expenditure into current and capital does not conform to international standards. Reporting annual data according to the methodology outlines in the GFSM 2001 for the Government Finance Statistics Yearbook and for sub-annual data for the International Financial Statistics is highly recommended. The most recently reported annual data were for 1997.

\section{Monetary accounts}

The authorities submit monetary statistics based on standardized report forms to STA on a regular and timely basis. However, the coverage of monetary data is incomplete, as data on depository corporations include only the accounts of the central bank and commercial banks and do not include credit unions. Data for other financial corporations are not reported.

\section{Balance of payments}

The compilation of the balance of payments is based on the fifth edition of the Balance of Payments Manual (BPM5). Belize completed the transition to the BPM5 in 2004. In addition, the authorities are refining the process for collecting relevant data that will enable the presentation of quarterly balance of payments statistics. As for the coverage, currentness and reporting of data for publication in the International Financial Statistics (IFS) and in the Balance of Payments Statistics Yearbook (BOPSY), Belize has reported annual data, albeit with a considerable lag. Belize does not compile International Investment Position (IIP) statistics. 


\section{External debt}

There are discrepancies between the data reported by the central bank and those reported by the ministry of finance, particularly with respect to gross external disbursements of the central government. In addition, the data reported by the central bank and the ministry of finance on the external debt of the public enterprises are incomplete and inconsistent with the information provided by the public enterprises. The authorities are seeking to reduce the discrepancies and inconsistencies by fostering greater cooperation among the agencies involved.

\section{Development Finance Corporation}

The accounts of the DFC, which is a major instrument of the government's economic policy, are not well integrated into monetary or fiscal accounts. 


\section{Belize: Table of Common Indicators Required for Surveillance}

(As of September 20, 2006)

\begin{tabular}{|c|c|c|c|c|c|}
\hline & $\begin{array}{c}\text { Date of Latest } \\
\text { Observation }\end{array}$ & $\begin{array}{c}\text { Date } \\
\text { Received }\end{array}$ & $\begin{array}{l}\text { Frequency } \\
\text { of Data }\end{array}$ & $\begin{array}{c}\text { Frequency } \\
\text { of } \\
\text { Reporting }\end{array}$ & $\begin{array}{l}\text { Frequency of } \\
\text { Publication }\end{array}$ \\
\hline \multicolumn{6}{|l|}{ Exchange Rates } \\
\hline $\begin{array}{l}\text { International Reserve Assets and Reserve Liabilities of } \\
\text { the Monetary Authorities } 1\end{array}$ & $04 / 28 / 06$ & $04 / 28 / 06$ & $\mathrm{~W}$ & W & NA \\
\hline Reserve/Base Money & $7 / 31 / 06$ & $9 / 01 / 06$ & W & $\mathrm{W}$ & NA \\
\hline Broad Money & $7 / 31 / / 06$ & $9 / 01 / 06$ & $\mathrm{~W}$ & $\mathrm{~W}$ & NA \\
\hline Central Bank Balance Sheet & $7 / 31 / 06$ & $9 / 01 / 06$ & $\mathrm{~W}$ & $\mathrm{~W}$ & NA \\
\hline Consolidated Balance Sheet of the Banking System & $7 / 31 / 06$ & $9 / 01 / 06$ & M & M & NA \\
\hline Interest Rates $^{2}$ & $7 / 31 / 06$ & $9 / 07 / 06$ & M & M & NA \\
\hline Consumer Price Index & May 2006 & $6 / 15 / 06$ & Q & Q & NA \\
\hline $\begin{array}{l}\text { Revenue, Expenditure, Balance and Composition of } \\
\text { Financing }{ }^{3-} \text { General Government }\end{array}$ & Mar. 2003 & Dec. 2003 & A & A & NA \\
\hline $\begin{array}{l}\text { Revenue, Expenditure, Balance and Composition of } \\
\text { Financing }{ }^{3} \text { - Central Government }\end{array}$ & June 2006 & $8 / 18 / 06$ & M & M & NA \\
\hline $\begin{array}{l}\text { Stocks of Central Government and Central Government- } \\
\text { Guaranteed Debt }\end{array}$ & June 2006 & $9 / 20 / 06$ & M & M & NA \\
\hline External Current Account Balance & June 2006 & $8 / 18 / 06$ & Q & Q & A \\
\hline Exports and Imports of Goods and Services & June 2006 & $8 / 18 / 06$ & M & M & NA \\
\hline GDP/GNP & 2005 & $8 / 18 / 06$ & A & A & NA \\
\hline Gross External Debt & June 2006 & $9 / 20 / 06$ & $\mathrm{~A}, \mathrm{M}$ & $\mathrm{A}, \mathrm{M}$ & NA \\
\hline
\end{tabular}

${ }^{1}$ Includes reserve assets pledged or otherwise encumbered as well as net derivative positions.

${ }^{2}$ Both market-based and officially-determined, including discount rates, money market rates, rates on treasury bills, notes and bonds.

${ }^{3}$ Foreign, domestic bank, and domestic nonbank financing.

${ }^{4}$ The general government consists of the central government (budgetary funds, extra budgetary funds, and social security funds) and state and local governments.

${ }^{5}$ Including currency and maturity composition.

${ }^{6}$ Daily (D), Weekly (W), Monthly (M), Quarterly (Q), Annually (A); Irregular (I); Not Available (NA). 


\section{Appendix VI. Medium-Term Scenario Assumptions}

1. This Appendix describes the main assumptions that are embodied in the staff's medium-term scenarios.

\section{A. Medium-Term Scenario Assumptions}

2. For the analysis of the medium-term prospects of Belize's economy, staff simulated two scenarios. A first passive scenario was predicated upon the broad continuation of current policies. The outcome of this scenario was contrasted with a second (active) scenario based on significant additional policy adjustment, additional support from bilateral and multilateral lenders, and the closure of remaining financing needs, including through a restructuring of the commercial external debt.

3. A number of assumptions are common to both scenarios. These include, most importantly, the assumptions about the production and fiscal revenue from oil, as laid out in Box 2 of the main text and based on oil prices as reflected in the September 2006 World Economic Outlook (WEO). In addition, the price assumptions (consumer prices and GDP deflator) are common and predicated to fulfill the purchasing power parity conditions in the medium term under the fixed exchange rate regime.

\section{Main assumptions under the passive scenario}

4. In broad terms, the passive scenario is thought to replicate a "muddle-through" situation, in which policies remain essentially unchanged, and financing gaps are filled through borrowing on market terms. Because this scenario implies a high degree of uncertainty about the country's external and fiscal sustainability, investment levels are expected to be depressed and thus put a relatively low ceiling on growth.

- Real GDP growth: Gross fixed investment is projected to decline to 14 percent in the longer run, constraining the underlying real GDP growth rate to a modest 3 percent. This underlying growth rate is adjusted for the expected impacts of cyclical factors, preference erosion for sugar and bananas, and expected oil production (see Box below).

- Fiscal policy: The passive scenario is based on an unchanged primary surplus effort of about 3.3 percent of GDP. No significant fiscal adjustment will be undertaken beyond FY 2006/07, and it is assumed that the introduction of the general sales tax (GST) on July 1, 2006 will have a slightly negative impact on tax collection. In addition, the constant primary surplus assumption implies that revenue from oil is not saved but used to raise current expenditures. 
- Reserves accumulation: The passive scenario does not foresee any room to accumulate reserves beyond a very modest level of US\$10 million per year. As a consequence, the reserves coverage of imports will remain very low throughout the projection period at less than $1 \frac{1 / 2}{2}$ months of imports.

\section{Main assumptions under the active scenario}

5. The staff's active scenario is predicated upon a strong policy response by the authorities, support from both bilateral and multilateral lenders, and closure of remaining financing needs, including through a successful debt exchange. The absence of uncertainty about fiscal and external sustainability is expected to foster confidence and catalyze a recovery of private investment, including from abroad. The increased investment flows are assumed to mainly benefit the tourism sector and, to a lesser extent, the nontraditional export sectors. Their effect in the short term will be to raise imports, while over the longer term a higher rate of growth of goods and services exports is expected.

- Real GDP growth: Higher gross fixed investment of about 17 percent of GDP in the medium term is expected to raise the underlying real GDP growth rate to 4.2 percent.

- Fiscal policy: The active scenario foresees an additional primary surplus effort over the medium term, with some frontloading during 2007-09, to demonstrate commitment and reduce immediate vulnerabilities. The primary effort declines slightly in the outer years as the additional revenue from oil tapers off and is only partially substituted through additional non-oil tax revenue and a decline in current expenditure. In FY 2006/07, additional expenditures for exceptional interest fees and charges of about 0.5 percent of GDP are assumed to cover the costs of the debt exchange.

- Reserves accumulation: The active scenario targets a more ambitious recovery of gross international reserves to about 2.5 months of imports by 2015. This is achieved through an annual accumulation of reserves to the tune of US\$25 million. 


\section{Box. Growth Prospects for Belize}

Belize's growth prospects depend to a large extent on the level of investment that the country will be able to sustain in the medium and longer term. While growth has historically been strong, this performance rested on very high levels of public sector investment, which over the past 15 years averaged $12 \frac{1}{2}$ percent of GDP (see Table below). ${ }^{1}$ Because of relatively modest and declining public savings, these levels of investment proved unsustainable and are therefore unlikely to be repeated in the future. In the circumstances, the mobilization of private sector investment will be a key factor in determining Belize's mediumterm growth trend.

The staff's medium-term framework provides for two scenarios for underlying growth in the economy. In the passive scenario, gross domestic investment will remain constrained by the uncertainty that derives from the fragile balance of payments and debt situation. Gross fixed capital formation is projected to decline to about 14 percent of GDP in the longer term as a consequence of lower Average Economic Growth and Investment Rates, 1991-2005

\begin{tabular}{lrrr}
\hline & Belize & Caribbean 1/ & Latin America 1/ \\
\hline 1991-1999 & (in percent of GDP, unless indicated otherwise) \\
GDP growth, percent & 5.3 & 2.9 & 3.7 \\
Gross capital formation & 23.4 & 26.1 & 19.6 \\
o/w public & 12.2 & 6.7 & 4.7 \\
o/w private & 11.2 & 19.4 & 14.9 \\
2000-2005 & & & \\
GDP growth, percent & 6.7 & 2.3 & 2.8 \\
Gross capital formation & 21.5 & 26.9 & 18.6 \\
o/w public & 10.8 & 6.7 & 4.3 \\
o/w private & 10.7 & 20.2 & 14.3 \\
1991-2005 & & & \\
GDP growth, percent & 5.9 & 2.6 & 3.3 \\
Gross capital formation & 22.7 & 26.4 & 18.9 \\
o/w public & 11.6 & 6.7 & 4.5 \\
o/w private & 11.0 & 19.7 & 14.7 \\
\hline 1/ Simple averages. & & &
\end{tabular}
private investment, while public investment would stabilize at about 4 percent of GDP. With estimated TFP growth of 0.7 percent (around the average experienced in 1991-2005), this would allow Belize to grow at a real rate of about 3 percent in the medium term. In the active scenario, the return to a sustainable position through the restructuring of the foreign commercial debt and sound macroeconomic policies is expected to foster confidence and catalyze a recovery of private investment, including FDI, to bring gross fixed investment to a level of 17 percent of GDP. With somewhat higher TFP growth than in the passive scenario on account of the increased share of private investment, trend growth would be expected to rise to about 4.2 percent in the medium term.

The forecasts for underlying growth in both scenarios are further adjusted to reflect cyclical factors, the impact of the recent oil discovery and the erosion of trade preferences (see Chart below). With the economy in deceleration, the underlying growth rate of the non-oil economy is assumed to be temporarily depressed to 1 and 2 percent in 2006 and 2007 respectively, and the

Real Growth Rate Projections (percentage change)

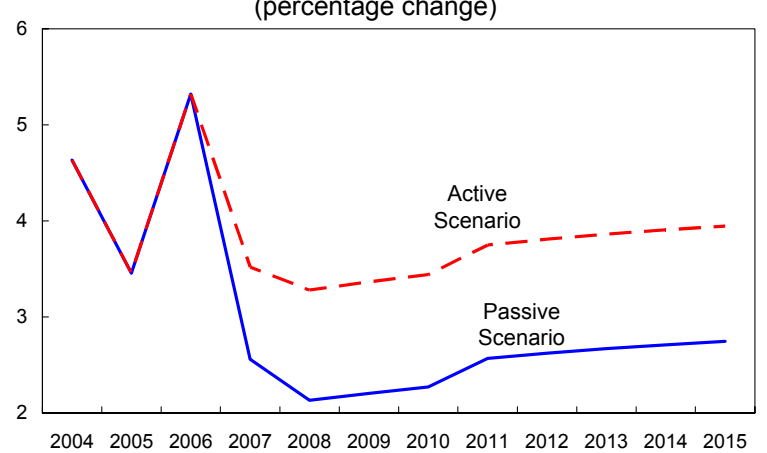
impact of eroding trade preferences is assumed to depress growth by another $1 / 4$ percentage point over the next four years. However, in the short term, these effects will be more than offset during 2006 and 07 by the impact of oil production. In the outer years, oil production is set to decline and will push real GDP growth somewhat below the estimated underlying trend rate.

\footnotetext{
${ }^{1}$ The past level of public investment in Belize is somewhat overestimated because of a misclassification of current expenditure as capital outlays.
} 


\section{Appendix VII. The Structure of Public Debt}

1. As of June 30, 2006, Belize's public and publicly guaranteed debt stood at US\$1,088 million (93.5 percent of GDP). The main structural characteristics of this debt are as follows:

- The overwhelming majority of the public and publicly guaranteed debt is owed to external creditors and denominated in foreign currency (Appendix VII. Figure 1). As of June 2006, external creditors held over 90 percent of total debt (86 percent of GDP). All external debt is foreign currency denominated and unhedged. The small amount of domestic public debt consists mainly of loans and treasury bills and notes held by banks. The marginal relevance of domestic debt reflects the underdevelopment of Belize's domestic financial markets.

- Commercial creditors hold more than 60 percent of the external public debt (Appendix VII. Figure 1). The remainder of the external debt is held by multilateral creditors (23 percent), mainly CDB and IADB; bilateral creditors (16 percent), mainly Taiwan Province of China; and export credit (1 percent).

Appendix VII. Figure 1. Public Debt Composition
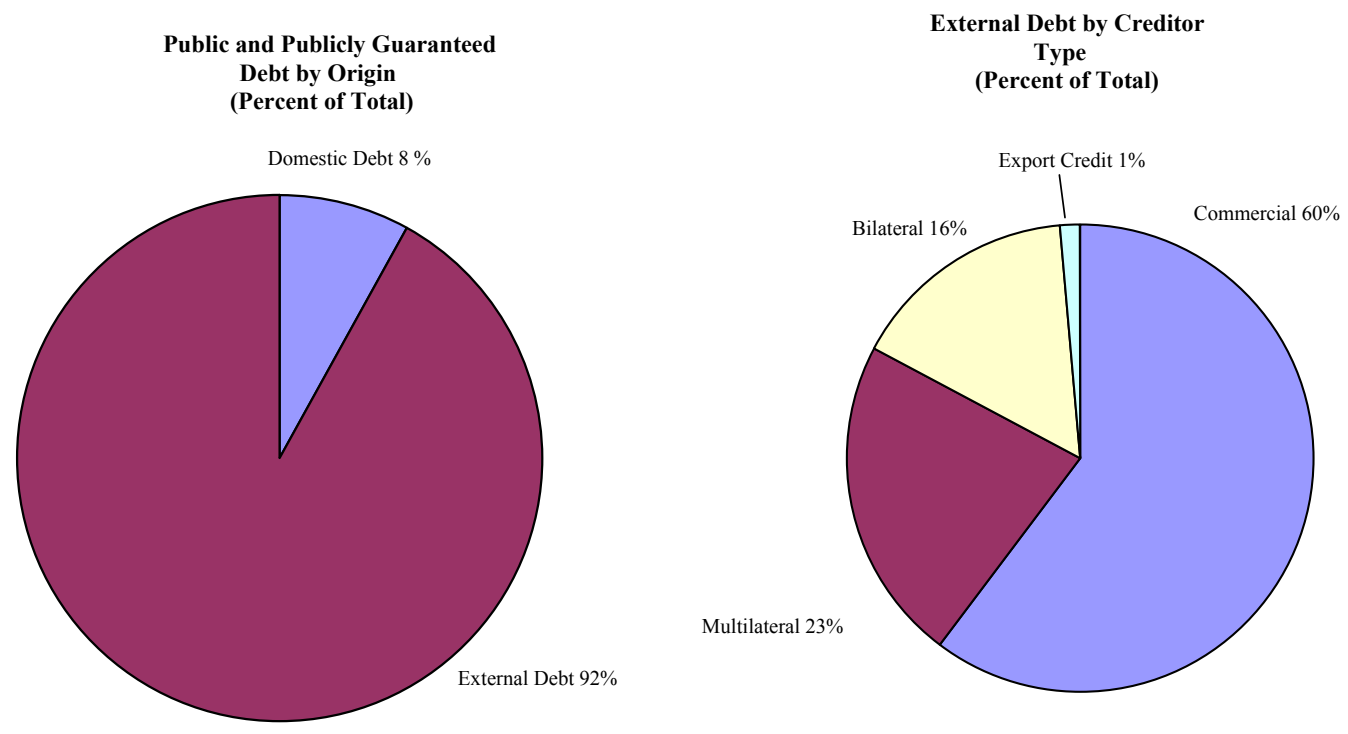

- About 80 percent of the external debt to private creditors is made up by 5 large and relatively recent bond and note issuances. These include two global bonds maturing in 
2012 and 2015, for US\$125 million and US\$100 million, respectively; a US\$76 million 10-year note due in 2014 but containing a put option that is exercisable starting from October 2007; and two insured notes maturing in 2010 and 2015, in the amounts of US\$71 million and US\$65 million at issuance, respectively. The remainder consists of smaller bank loans and residual amounts of mostly older external bond and note issuances.

- The average interest rate charged by commercial creditors is substantially higher than that charged by bilateral and multilateral creditors. The wide difference reflects concessional terms from official creditors and to some extent, the market perception of credit risks. The average interest rate of the commercial debt, however, is an underestimated cost indicator of the government financing because of several explicit or implicit credit-enhancement features (see below).

- Several of the private commercial debt instruments include credit enhancement features. These include:

(i) Embedded put options. When the DFC failed to service a loan from Royal Merchant Bank of Trinidad and Tobago (RMBTT), the government assumed the liability as part of its guarantee agreement and refinanced it in 2004 by issuing a US\$76 million note. The note was scheduled to mature in 2014, but included a put option that can be exercised starting in October 2007.

(ii) Guarantees and/or collateral. Examples of guaranteed debt include a US\$6 million loan to the Belize Airport Authority and a US\$24 million loan by the Belize Port Authority. Bonds issued by the DFC's subsidiary Belize Mortgage Company (BMC) under the so-called "North American Securitization" program, with a remaining balance of US\$31 million, carry a government guarantee and are collateralized by a pool of real estate mortgages, and a loan from the former owner of the Belize water company is collateralized by physical shares.

(iii) Insurance. Two notes with face values of US\$65 million and US\$71 million that were issued by the government in March 2005 through a private placement, carry insurance that would cover 95 percent of the principal and interest payments in case of a default. In addition, the government was required to establish up front several reserve accounts to cover the insurance premia for the lifetime of the bonds, the uninsured 5 percent of principal and interest payments, and 180 days of debt service. Class A of the $\mathrm{BMC}$ bonds also carries insurance in case the government defaults on its guarantee. 
- The public debt-service profile of external commercial debt exhibits humps and an uneven distribution of the debt burden. A cash-flow projection model, based on the terms and conditions contained in each debt contract - including the schedule of future coupon payments, principal repayments, collateral, reserve release, and other debt properties such as options - indicates that the medium-term debt service profile displays humps in 2007, 2010, 2012, and 2015 (Appendix VII. Figure 2). In addition, the monthly debt service payments vary greatly in the near term, ranging from US\$0.5 million to US\$13 million (Appendix VII. Figure 3).

Appendix VII. Figure 2. Projected Annual Debt Service Payments (US\$ million)

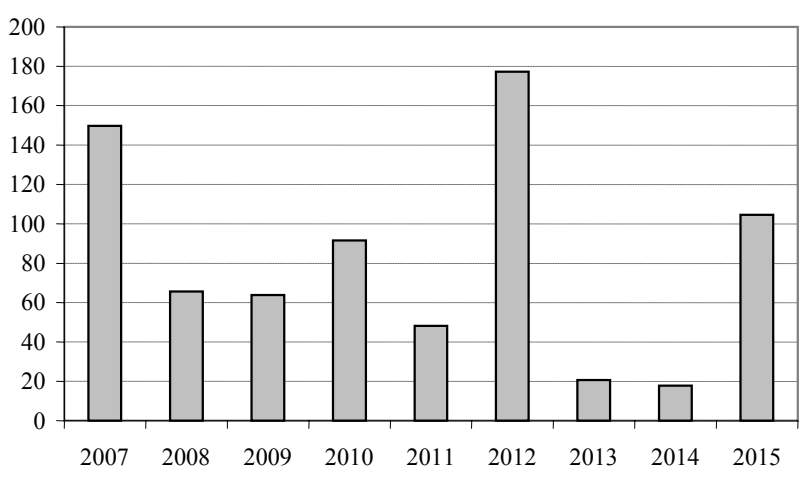

Appendix VII. Figure 3. Projected Monthly Debt Service Payments (US\$ million)

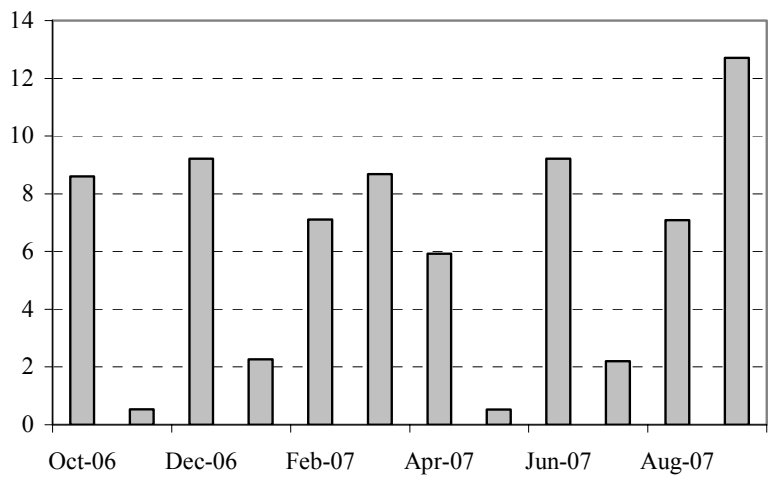




\section{Appendix VIII. Debt Sustainability Analysis}

1. Staff performed debt sustainability analyses (DSA) for both the passive and the active policy scenarios. Debt service projections in both scenarios are based on the following data:

- Data for debt service on bilateral and multilateral debt are taken from the Central Bank of Belize (CBB).

- Projections for commercial debt service are based on IMF staff files, which were compiled on a loan-by-loan basis from the original documentation for central government debt.

2. The debt stock in the staff's DSA covers central government debt and the publicly guaranteed external debt of quasi-fiscal entities. Regarding the external quasifiscal debt, the DSA assumes that these entities will service interest payments from their own resources. In the case of the DFC, the DSA assumes that amortization payments are fully assumed by the central government, who is able to recoup two-thirds of them through the sale of DFC assets (these are recorded as privatization proceeds, below the line). The other publicly guaranteed debt is assumed to be rolled over and remains constant at its end-2005 level.

3. As a way of simplification, the DSA assumes standard financing terms for assistance from bilateral and multilateral lenders, and domestic financing. Such financing is assumed to carry interest of 6-month LIBOR plus one percent, and a 20-year term with amortizations occurring on a half-yearly basis after a grace period of three years. ${ }^{17}$ Domestic debt is assumed to be rolled over at existing terms and new financing is being contracted at a flat interest rate of 8 percent, which is about the average cost of the past 5 years.

\section{The residual financing gaps are filled through external financing at market}

terms. The DSA assumes that this occurs through the issuance of either 5-year notes (passive scenario) or 10-year bonds (active scenario) with a bullet maturity. The projected interest rates on these borrowings equals the current market projections for 5- and 10-year U.S. Treasury bonds, plus a country risk premium, or spread (discussed further below). It is assumed that $1 / 4$ of the annual interest payments will fall due in the year of contracting the new loans (i.e., half the loans are taken up in the first half of the year, for which one halfyearly interest payment will be made in the second half of the year).

\footnotetext{
${ }^{17}$ The simulations use WEO projections of future rates for 6-month LIBOR.
} 


\section{Debt sustainability in the passive scenario}

5. In addition to the macroeconomic assumptions that have been described earlier, the passive DSA is predicated upon the following:

- Bilateral and multilateral financing is expected to become available only in very modest and declining quantities. Multilateral financing is limited to previously identified lending, while bilateral financing is assumed to remain at a level of US\$10 million per year through 2015 on a gross basis. Domestic financing is assumed to be available at about US\$5 million per year in net terms.

- Sovereign risk spreads would remain high, projected in the simulations at 900bps, given the large debt burden and market financing needs.

6. Under these assumptions, the public debt would not stabilize in the longer run. While the debt-to-GDP ratio would initially fall from about $981 / 2$ percent at end-2005 to about $84 \frac{1}{2}$ percent in 2012, it would shift back to a rising trend thereafter (Table 8 and Appendix VIII. Table 1). The reason for this turnaround in the debt dynamics is that after an initial decline in interest payments in 2006 and 2007, reflecting partly the absence of exceptional financing fees and commissions, the public interest bill is projected to climb to about 9 percent of GDP by 2015. This increase in interest payments is due to the fact that more and more debt is being refinanced at (higher) market terms. ${ }^{18}$ As a result of this process, the stable primary surplus translates into a gradually widening overall deficit in the outer years, which starts adding to the debt stock.

7. Sensitivity analysis highlights the extremely vulnerable debt position that Belize would sustain in an unchanged policies scenario. Bound tests such as a higher real interest rate of one standard deviation, a lower real GDP growth rate or primary surplus of one-half standard deviation each, a one-time real depreciation of 30 percent, or a 10 percent increase in the debt stock (reflecting situations such as an unexpected need to recapitalize the banking sector or to finance large emergency and reconstruction spending following a natural disaster) would lead to more explosive debt dynamics (Appendix VIII. Figure 1).

\footnotetext{
${ }^{18}$ A significant amount of Belize's external commercial loans are based on complex financial structures that compensated very high upfront fees with lower coupon payments.
} 
Debt sustainability in the active policy scenario

8. Apart from the more favorable macroeconomic environment in an active policy scenario, Belize would be expected to encounter a generally more benign financing environment. In this context, the DSA assumes the following:

- Bilateral and multilateral lenders are projected to provide additional support for the envisaged adjustment. In particular, it is assumed that in addition to previously identified lending, there will be policy-based loans from the IDB and CDB of US $\$ 25$ million each, with disbursements during the last quarter of 2006 through early 2008. Afterwards, it is assumed that Belize can secure a moderate flow of financial support from multilateral lenders of about US\$12.5 million per year (on a gross basis) through 2015. Bilateral lenders are assumed to provide more upfront support, through additional lending to the tune of US\$25 million in 2007. Domestic financing, by contrast, is assumed to be lower than under the passive scenario, particularly in the early projection years, as the government pays back on its overdraft to the central bank to support the accumulation of international reserves.

- Country risk is expected to decline gradually as the adjustment program takes hold and the debt stock declines. Following a successful debt exchange, spreads are assumed to decline from $550 \mathrm{bps}$ in 2007 to 275 bps by 2015 .

9. The debt dynamics in an active policy scenario would be significantly more favorable, although the precise trajectory would depend on the terms at which residual financing needs are being covered. Closing the financing needs at estimated market terms would lead the debt-to-GDP ratio to decline steadily from about 981/2 percent in 2005 to 67 percent by 2012 and 54 percent by 2015 (Table 10 and Appendix VIII. Table 2). This decline would be largely driven by the higher primary surplus to which the authorities would commit in the active scenario. At the same time, the debt dynamics would also benefitcompared with the passive scenario-from more favorable financing conditions due to the mobilization of additional bilateral and multilateral financing, and lower risk spreads.

10. However, even in an active scenario the Belize's public debt burden would remain high for a prolonged period of time, and there would be significant vulnerability to adverse shocks. While the debt-to-GDP ratio would remain on a declining trend under all of the performed bound sensitivity tests, the occurrence of such shocks would significantly delay the return to safer levels of public debt (Appendix VIII. Figure 2). 


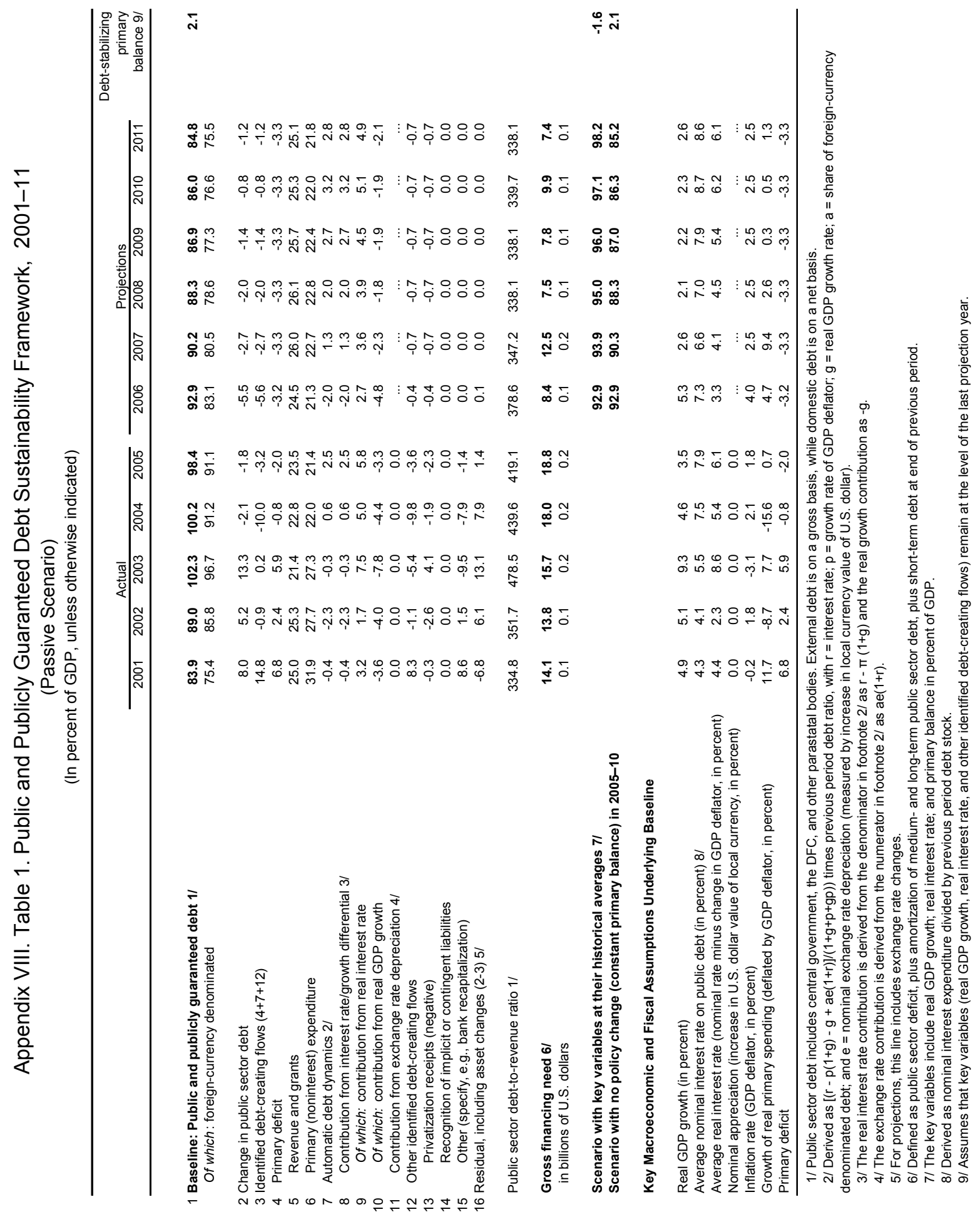


Appendix VIII. Figure 1. Public and Publicly Guaranteed Debt Sustainability: Bound Tests 1/

(Passive Scenario, in percent of GDP)
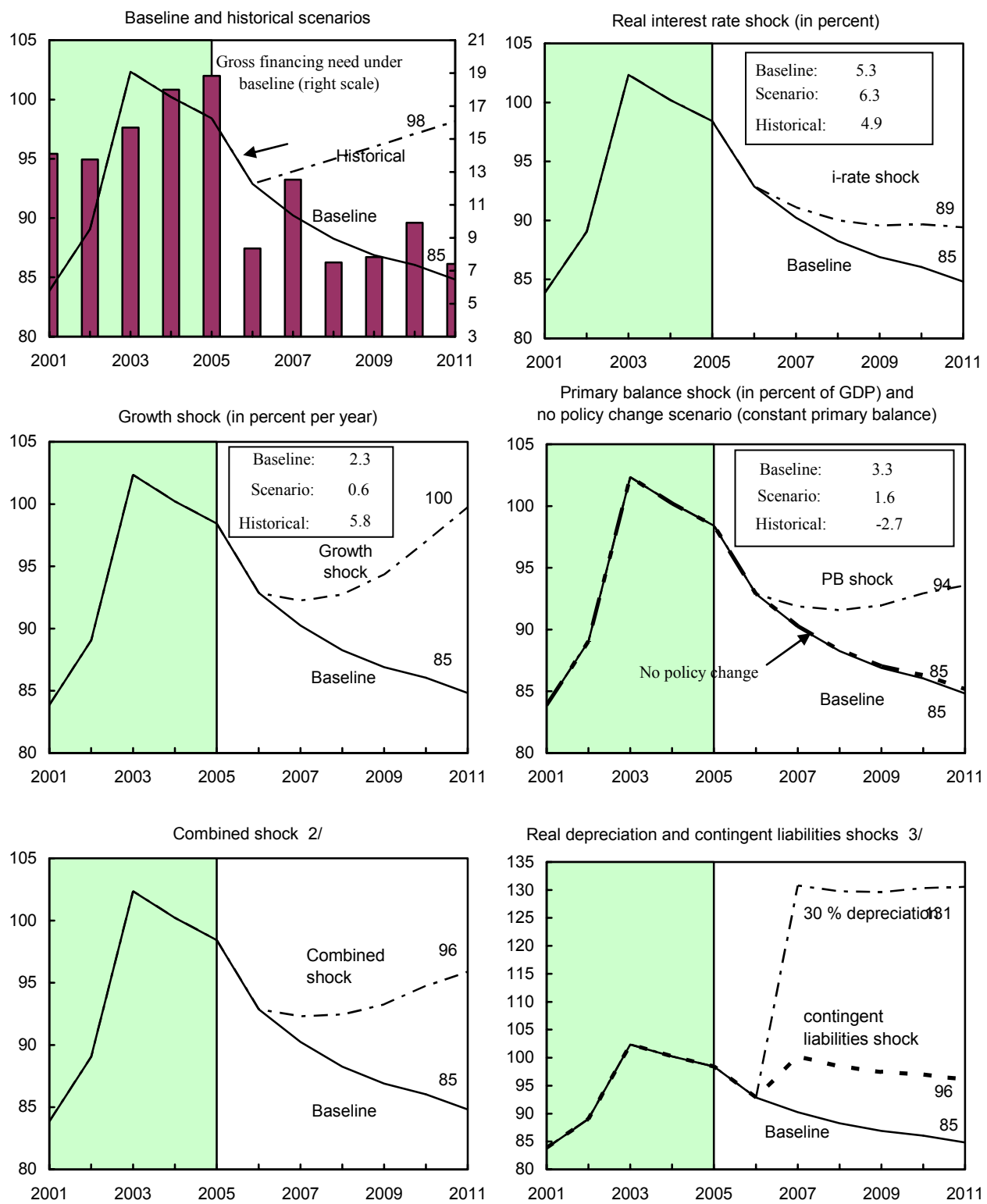

Real depreciation and contingent liabilities shocks $3 /$

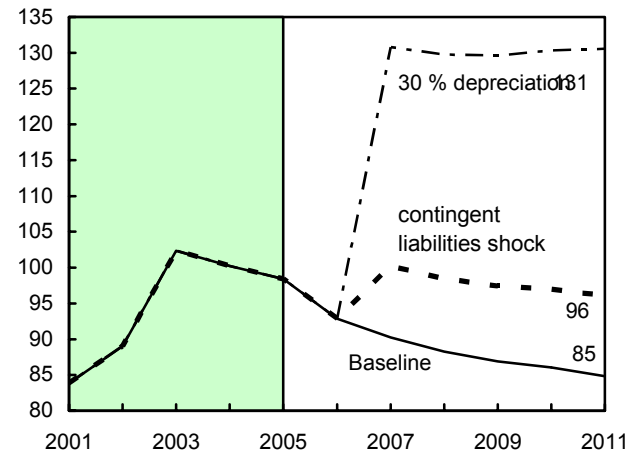

Sources: International Monetary Fund, Country desk data, and staff estimates.

1/ Shaded areas represent actual data.Individual shocks are permanent one-half standard deviation shocks. Figures in the boxes represent average projections for the respective variables in the baseline and scenario being presented. Ten-year historical average for the variable is also shown.

2/ Permanent 1/4 standard deviation shocks applied to real interest rate, growth rate, and primary balance.

3/ One-time real depreciation of 30 percent and 10 percent of GDP shock to contingent liabilities occur in 2006, with real depreciation defined as nominal depreciation (measured by percentage fall in dollar value of local currency) minus domestic inflation (based on GDP deflator). 


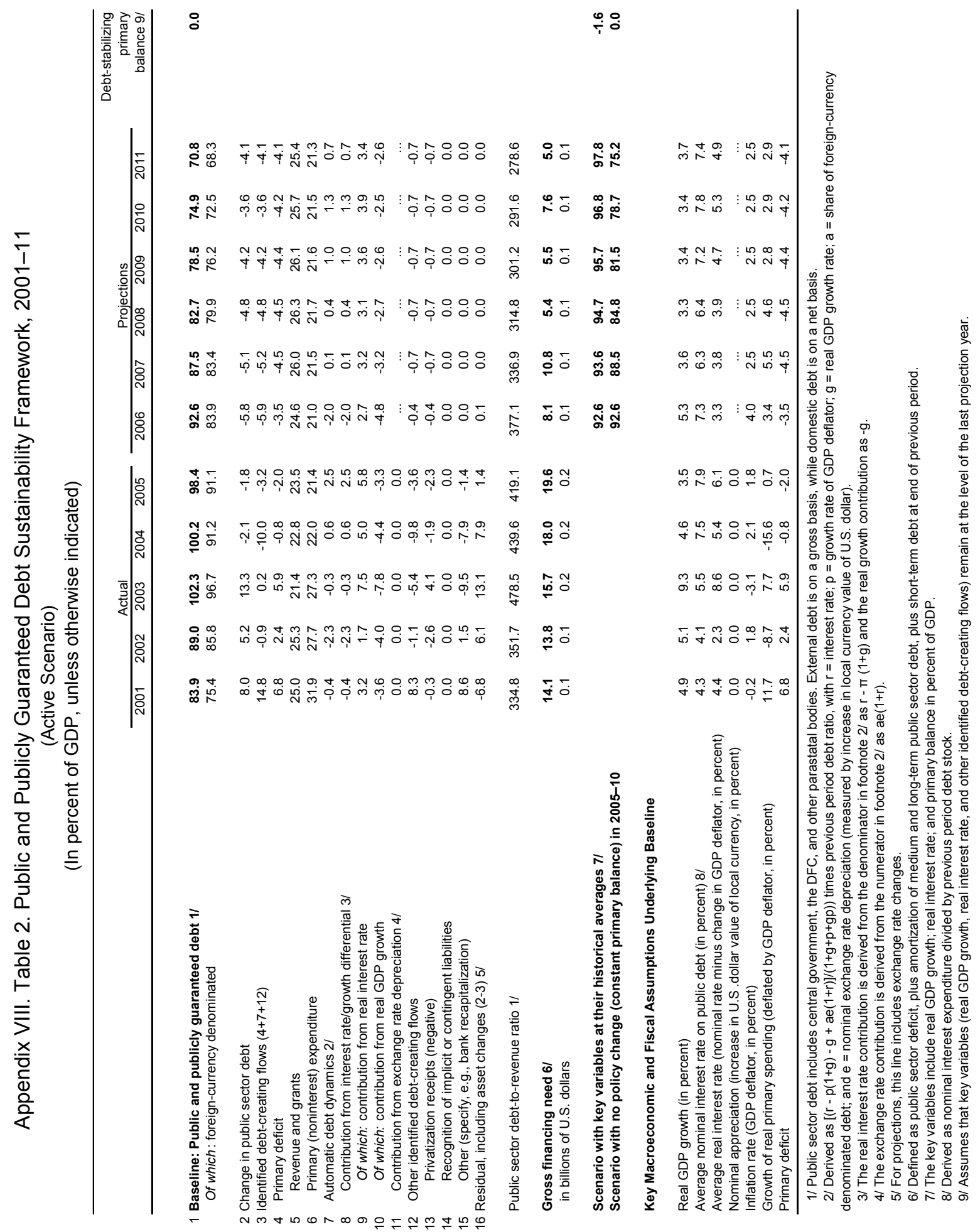


Appendix VIII. Figure 2. Public and Publicly Guaranteed Debt Sustainability:

Bound Tests 1/

(Active Scenario, in percent of GDP)

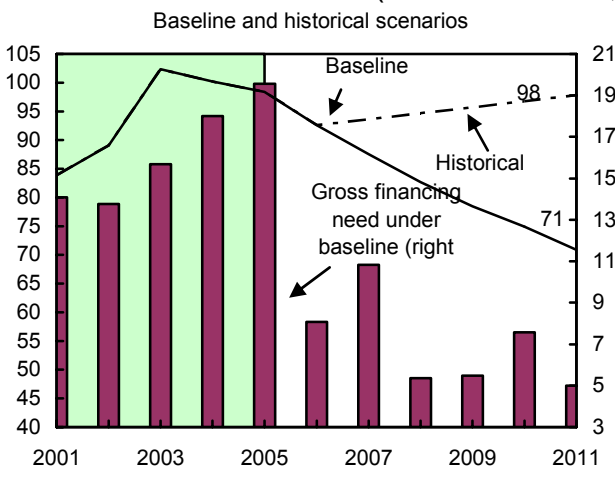

Real interest rate shock (in percent)
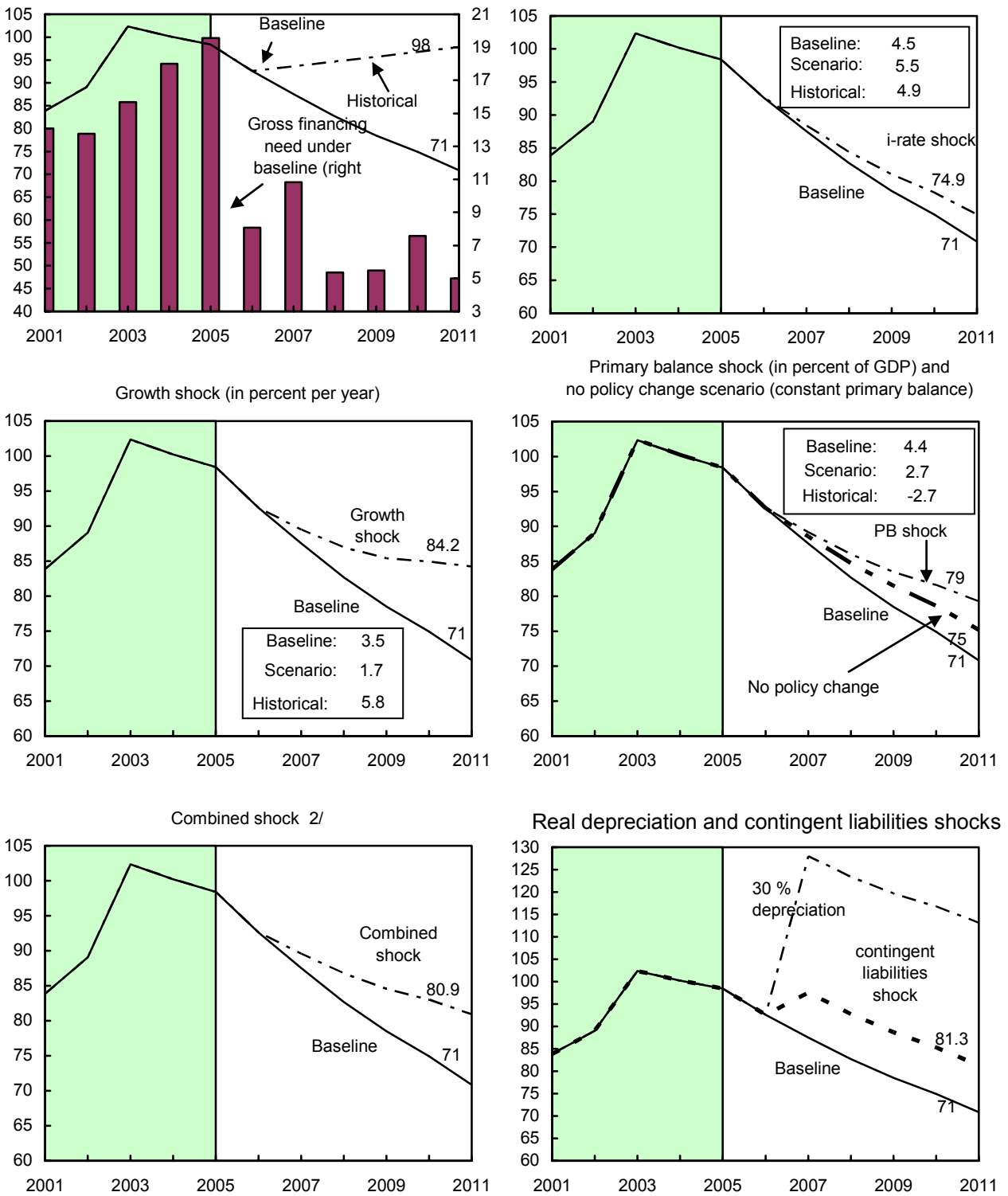

Real depreciation and contingent liabilities shocks 3/

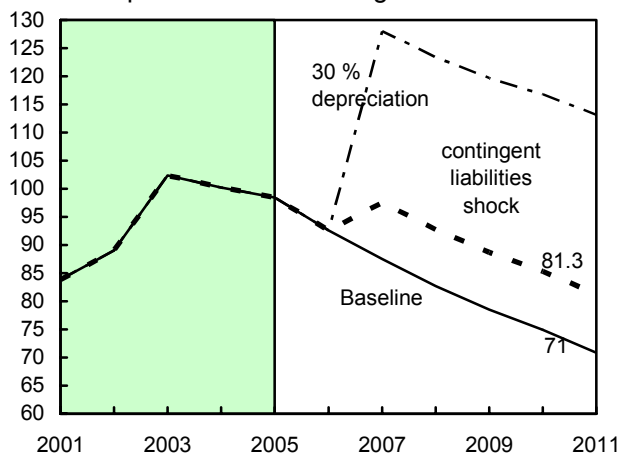

Sources: International Monetary Fund, Country desk data, and staff estimates.

1/ Shaded areas represent actual data.Individual shocks are permanent one-half standard deviation shocks. Figures in the boxes represent average projections for the respective variables in the baseline and scenario being presented. Ten-year historical average for the variable is also shown.

2/ Permanent 1/4 standard deviation shocks applied to real interest rate, growth rate, and primary balance.

3/ One-time real depreciation of 30 percent and 10 percent of GDP shock to contingent liabilities occur in 2006, with real depreciation defined as nominal depreciation (measured by percentage fall in dollar value of local currency) minus domestic inflation (based on GDP deflator). 


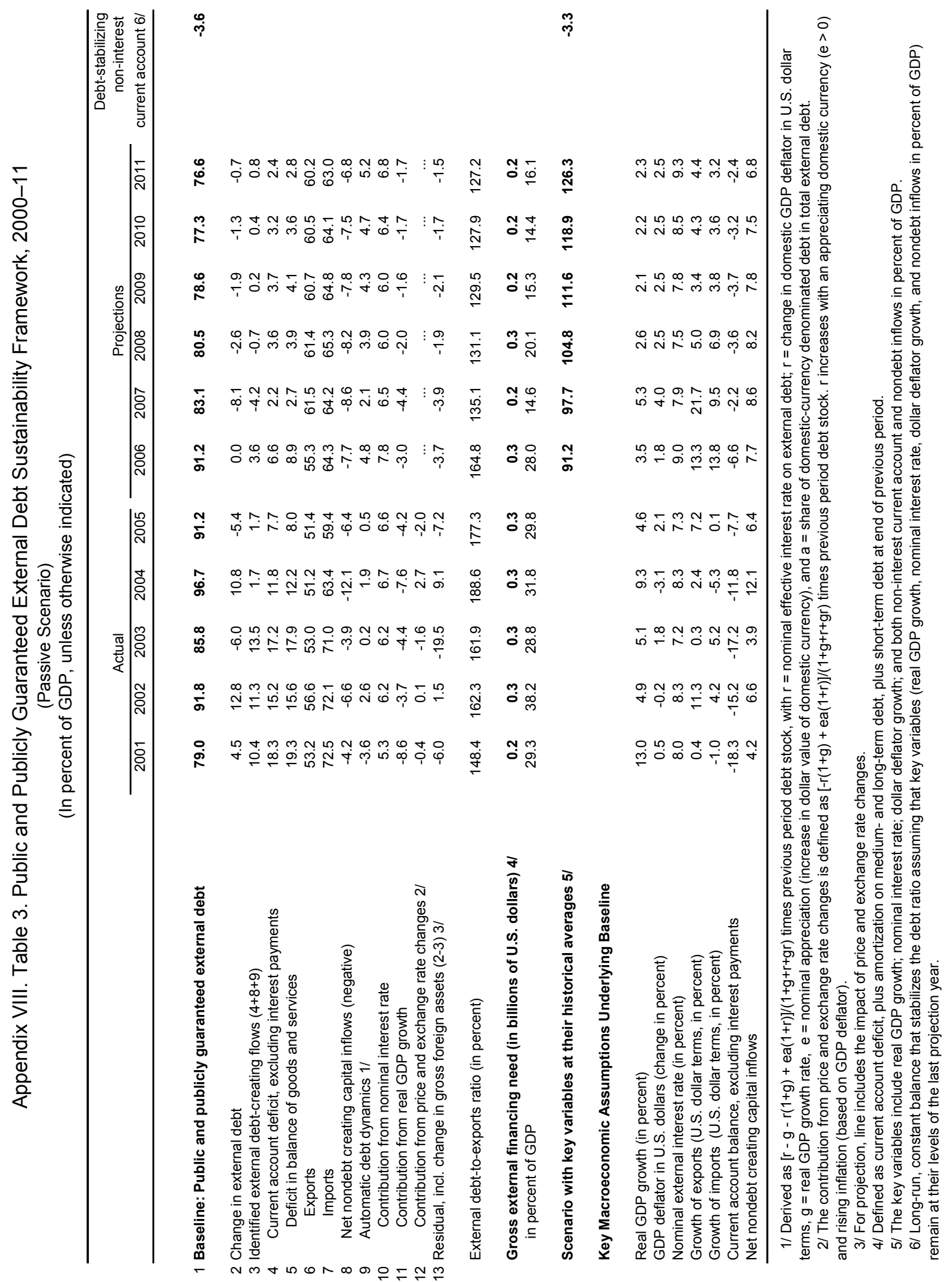


Appendix VIII. Figure 3. Public and Publicly Guaranteed External Debt Sustainability: Bound Tests $1 /$

(Passive Scenario, in percent of GDP)
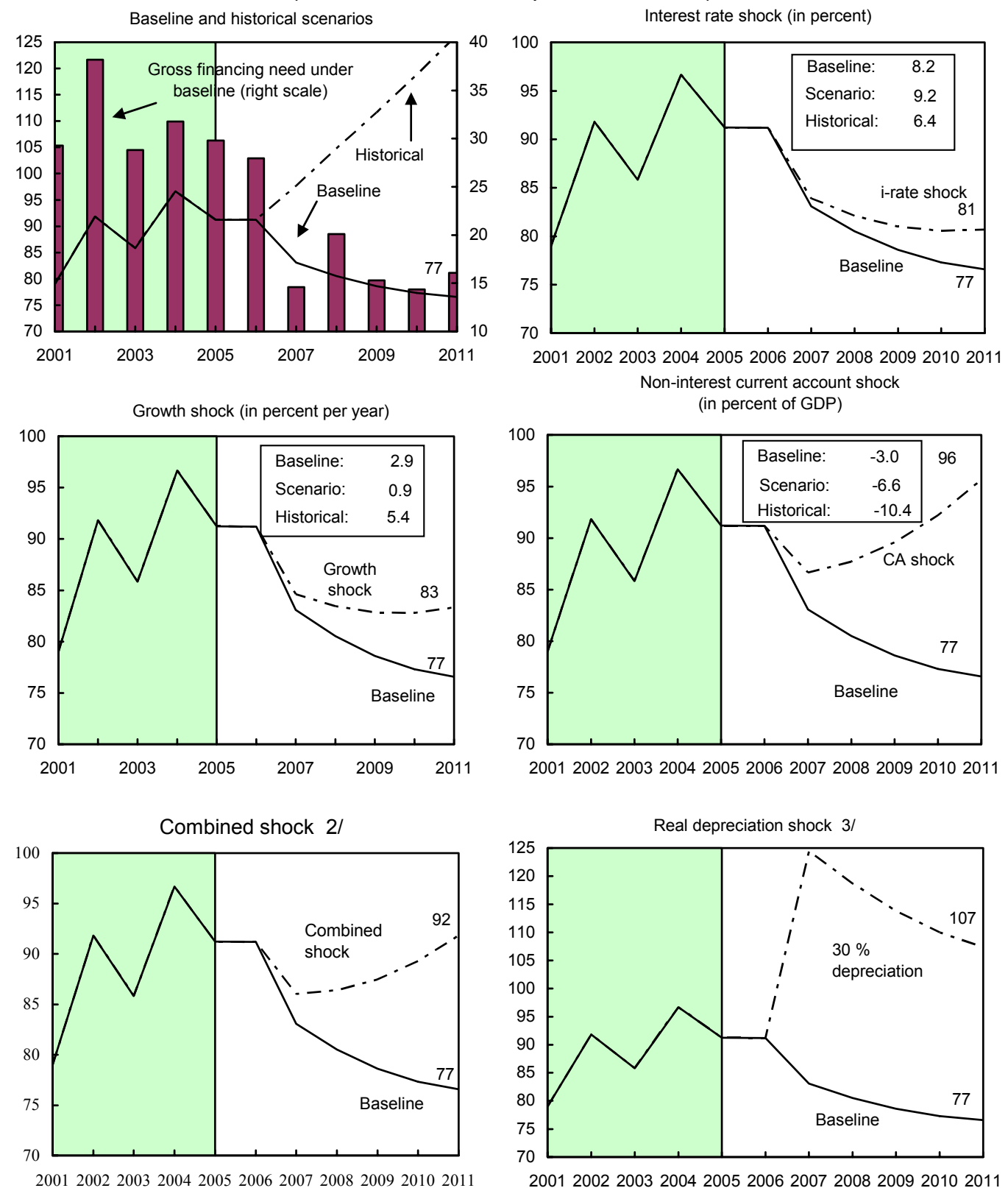

Sources: International Monetary Fund, Country desk data, and staff estimates.

$1 /$ Shaded areas represent actual data. Individual shocks are permanent one-half standard deviation shocks. Figures in the boxes represent average projections for the respective variables in the baseline and scenario being presented. Ten-year historical average for the variable is also shown.

2/ Permanent 1/4 standard deviation shocks applied to real interest rate, growth rate, and current account balance.

3/ One-time real depreciation of 30 percent occurs in 2006. 


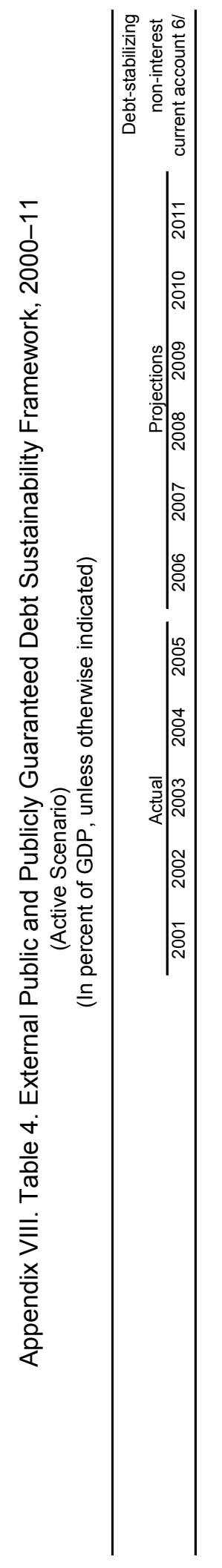

$\stackrel{4}{4}$

$\stackrel{\infty}{i}$

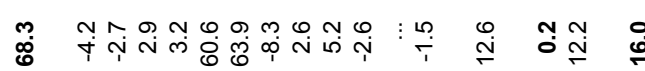

只

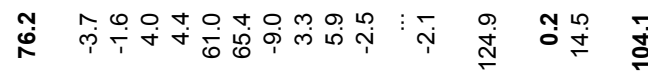

迎

芦

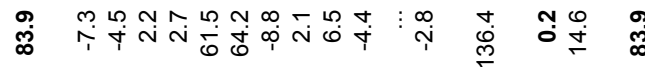

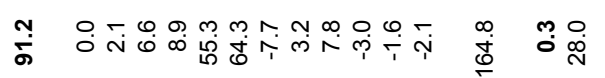

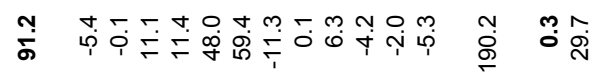

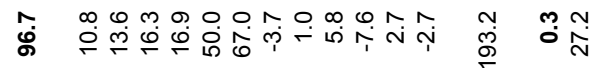

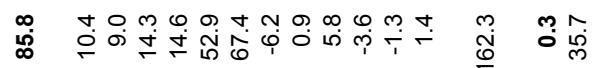

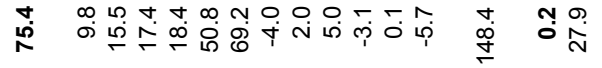

กิ

岀

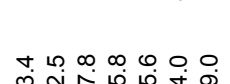

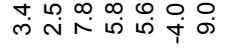

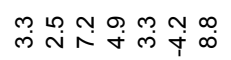

吕

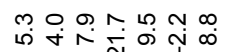

மூ

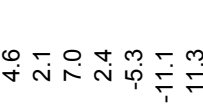

क̆

চூ

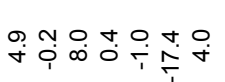

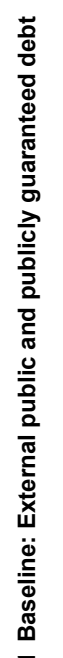

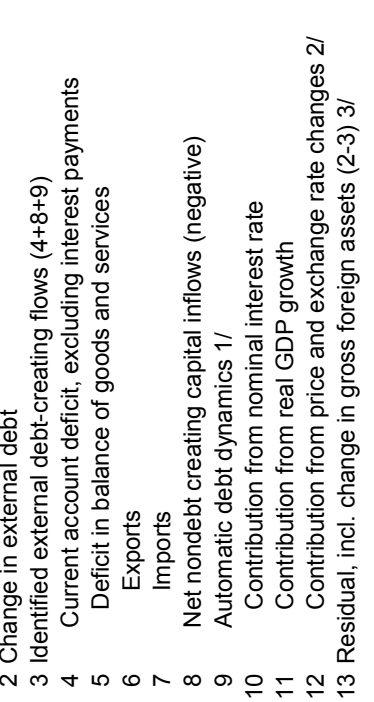

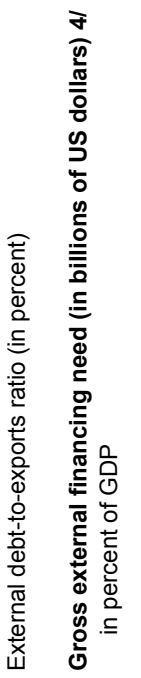

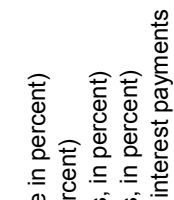

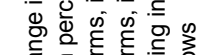

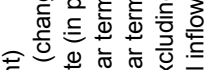

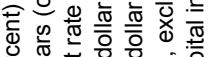

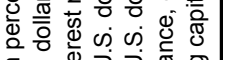

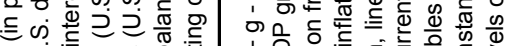

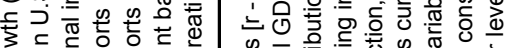

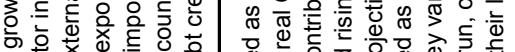
类

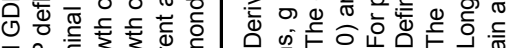

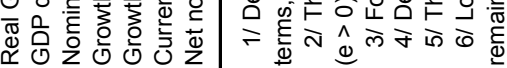




\section{Appendix VIII. Figure 4. External Public and Publicly Guaranteed Debt Sustainability: Bound Tests 1/ \\ (Active Scenario, in percent of GDP)}
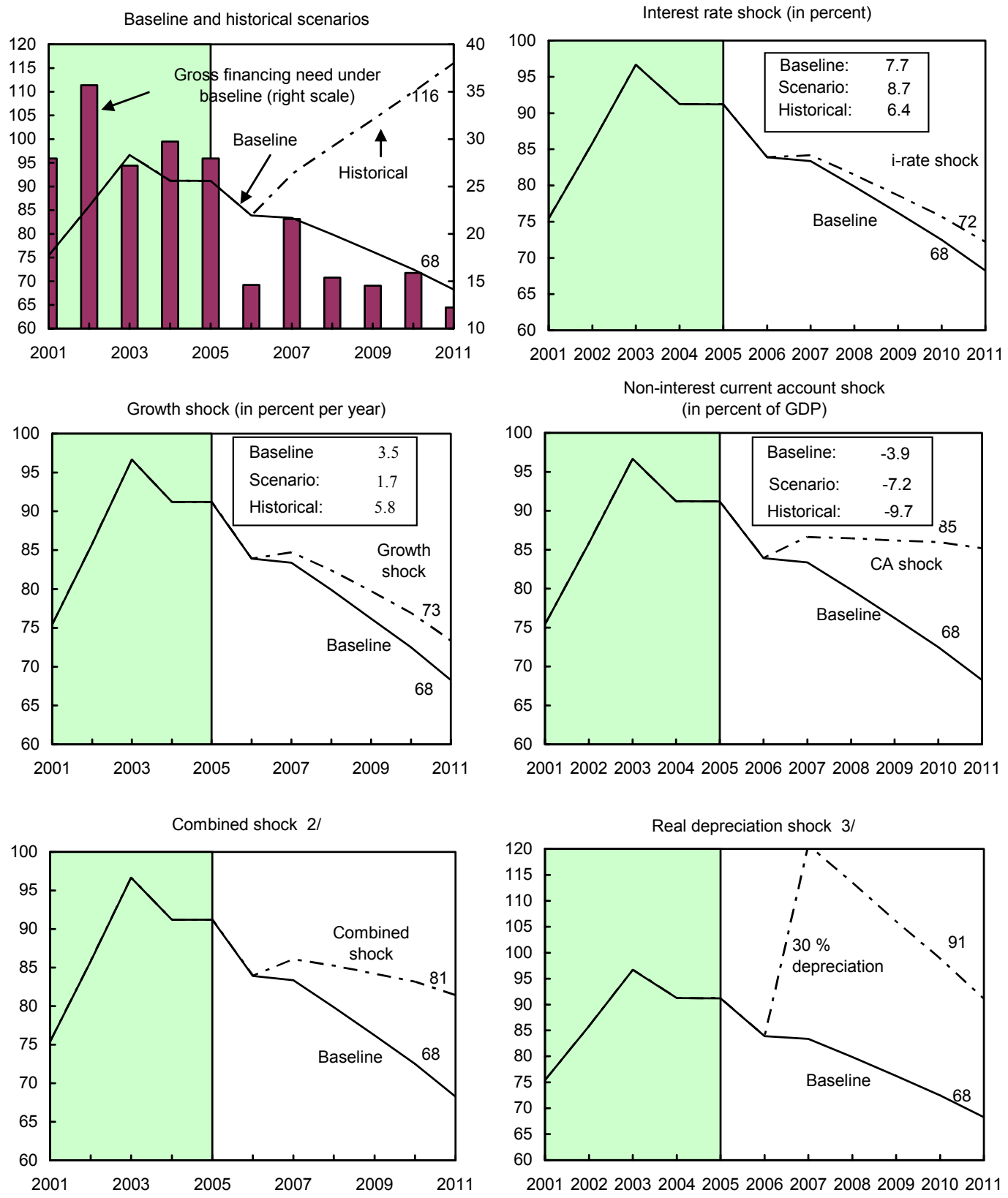

Sources: International Monetary Fund, Country desk data, and staff estimates.

$1 /$ Shaded areas represent actual data. Individual shocks are permanent one-half standard deviation shocks. Figures in the boxes represent average projections for the respective variables in the baseline and scenario being presented. Ten-year historical average for the variable is also shown.

2/ Permanent 1/4 standard deviation shocks applied to real interest rate, growth rate, and current account balance.

3/ One-time real depreciation of 30 percent occurs in 2006. 


\section{Statement by Jonathan T. Fried, Executive Director for Belize and Yvette Alvarez, Advisor to Executive Director \\ October 20, 2006}

\section{Key Points}

- The authorities moved to tighten policies in fiscal year 2004/2005 after a period of fiscal and monetary expansion, which resulted in large fiscal deficits and growth in external debt to unsustainable levels.

- While significant progress has been made in correcting macroeconomic imbalances, Belize continues to face acute fiscal and balance of payments gaps.

- Government has entered into good faith consultations with creditors with a view to restructuring the external debt.

The Belizean authorities wish to express their appreciation to the staff for the cordiality and frankness which characterized these consultations. These are difficult economic times in Belize and these consultations provided an excellent opportunity for exchange of views on the authorities' ongoing program to control the fiscal and balance of payments deficits and address the external debt on a collaborative basis with their creditors.

Late in 2004, the authorities recognized that, while the ambitious policy to promote growth through fiscal and monetary stimulation had resulted in unprecedented rates of economic growth, the fiscal deficit and the external debt had risen to unsustainable levels. In response, they began to take corrective measures to restore balance to avoid a potential fiscal and foreign exchange crisis so as to protect and sustain the exchange rate peg. These corrective measures took the form of short-term corrective action through revenue and expenditure measures as well as medium-term stabilization through fiscal reform and improved debt management.

The corrective measures were designed by the authorities as a home-grown program, but one which benefited from intensive consultations with international partners including the IMF. These consultations have been undertaken in an open and frank manner and, in this process, data flow and communication on policy and programming issues have been significantly improved. This has greatly improved the external environment within which the authorities are addressing the fundamental problems of medium-term fiscal and debt sustainability.

The short-term corrective action, which was implemented between October 2004 and March 2005, had the objective of halting the expansion in the fiscal deficit through an immediate cutback in the capital expenditure program and a reduction in planned operating costs by 5 percent during that 6 month period. 
The ongoing medium-term stabilization program, which began with the budget for fiscal year $2005 / 2006$, has the objectives of reducing the overall deficit to sustainable levels, and of attaining a sustainable external debt profile. The authorities recognized that this requires strong expenditure controls, tax reform, streamlining of the budget process, and the development and implementation of a comprehensive debt-management strategy. The medium-term strategy therefore includes:

- Strengthening of the public expenditure programming and management systems;

- Comprehensive reform and modernization of the revenue system, including the implementation of an ad valorem General Sales Tax on July 1, 2006;

- Definition of a debt-management strategy to bring sustainability to Belize's external debt profile and strengthen public debt management capacity, and

- Strengthening of the legal and administrative framework for financial accountability and oversight.

\section{Recent Developments}

The implementation of this medium-term program has already resulted in a significant fiscal correction. The primary balance has moved from a small deficit in FY 2004/2005 to a surplus of 3 percent of GDP in FY 2005/2006 and the overall deficit has been reduced from 8.6 percent of GDP to 3.3 percent of GDP, over the same period. Some 23/4 percent of GDP in exceptional fees and commissions on external loans that were incurred in FY 04/05 were not repeated in FY 05/06. These improvements reflect additional revenue measures implemented in May 2005 and strengthening in expenditure programming and controls.

The budget discipline which was shown last year is reflected in the outturn for the first quarter of the current fiscal year and it is expected that by the end of the current fiscal year, a primary surplus of $31 / 2$ percent of GDP will be attained (1/2 percent of GDP more than budgeted).

This fiscal adjustment program has been supported by Central Bank action to tighten financial sector liquidity. Social security deposits have been channeled to the Central Bank and the cash reserve and liquid asset requirements were increased four times during this period of adjustment.

Even with this strong adjustment underway, however, the low level of official foreign reserves and the heavy debt burden which is projected to continue beyond the medium term have signaled the urgency of the need to move quickly towards a sustainable external debt profile. With this objective in mind, the Belizean authorities engaged financial advisors late last year to support the preparation of a comprehensive debt management strategy. The implementation of this strategy has begun with the announcement, in August this year, that the Government was taking the very difficult step of approaching their private creditors to seek a restructuring of the external debt. 
This restructuring is being approached in a transparent and equitable manner. A detailed analysis of the situation including financial and economic projections has been published on the Central Bank of Belize's website, where additional information is also posted from time to time. The authorities are consulting extensively with the affected creditors to establish an understanding on what form of relief is needed to put Belize's external debt on a sustainable path. Once these consultations have been concluded, the authorities will make a formal debt restructuring offer in which creditors will be invited to participate.

\section{Policy Responses}

The Government's medium-term strategy builds on the comprehensive reform program launched in 2005. The authorities agree with the staff that long-term sustainability will require an additional fiscal effort of about 1 percent of GDP annually. This will allow for the achievement of an increase in the primary surplus to $4 \frac{1}{2}$ percent of GDP during the 2007-2009 period. In pursuit of this objective, the authorities are continuing to maintain the tight macroeconomic policies which characterize the adjustment programme.

They will continue to implement measures to keep the growth of non-interest current expenditure, including the wage bill, below that of nominal GDP, while allowing for a modest increase in capital spending for social sectors and infrastructure. In addition, a Public Expenditure Review, which was recently completed with the support of the IDB, has made several important recommendations that the authorities have agreed to implement early. These include the preparation of the annual budget in a multi-year context as well as the introduction of programme budgeting.

On the revenue side, the emphasis is on enhancing tax collections through improved efficiency. On July 1, 2006, a new General Sales Tax (GST) was introduced to replace the existing Sales Tax, which was applied on goods and services for importers and domestic producers and suffered from cascading effects and lack of buoyancy. The authorities are resisting pressures to dilute the GST base and are reviewing the performance of the GST as preparations are made to deepen the process of reform of tax administration.

With regards to monetary policy, the authorities are confident that the latest increase in the reserve requirements is sufficient at this time but are prepared to tighten these requirements further, should this prove necessary.

\section{Structural Reforms and Governance Issues}

The passage of the Finance and Audit (Reform) Act of 2005 crystallized the Government's commitment to strengthen and modernize the legal framework for the administration of the public finances in keeping with global trends towards greater accountability. However, the authorities recognize that they need to accelerate other structural reforms in the fiscal and monetary areas to sustain the positive results beyond the medium term. To this end, several reform efforts are of immediate priority. These include: 
1. Modernization of customs procedures to increase administrative efficiency and revenue

- Cabinet recently approved a project to modernize Customs administration to maximize efficiency in the Customs clearance process, which would allow for increased revenue collection, more timely and accurate trade statistics, and a reduction in the costs to the business community. This project was prepared with the assistance of UNCTAD.

2. Streamlining and improving the format of the budget and overall strengthening of budget management and reporting

- Over the past 2 budget preparation cycles, the format of the budget was streamlined to better conform to international standards of classification of financial transactions. The economic data is therefore significantly improved in quality at both the summary and disaggregated levels. Steps are being taken to ensure that fiscal data is submitted for inclusion in the IMF's Government Finance Statistics.

3. Creation of an autonomous Statistical Institute to improve the quality and timeliness of data to monitor economic activity

- The Government is taking steps to transform the Central Statistics Office (CSO) into an autonomous statistical institute with the support of international partners. This is expected to be implemented by the end of this fiscal year.

- In addition, after several months of collaborative work between the CSO and the IMF's Statistical Department, Belize began participating in the General Data Dissemination System in September 2006.

4. Introduction of a long term planning framework - Vision 2025

- Government has agreed to begin a process of consultation with all social partners, including the private sector, labour unions, political parties, nongovernment organization and community based organization with a view to building broad consensus on future policy direction.

The Staff Report (Box 1) notes that a lack of transparency and weak governance have contributed to the build-up in external public debt since 1999. In addition to the structural reform measures already outlined, the authorities have taken several steps to address issues of governance.

\section{The Social Security Board}

The Senate Select Committee Investigations into the operations of the Social Security Board (SSB) was concluded and submitted to the National Assembly in July 2006 and the Government moved immediately to accept and to implement the Report's recommendations. 


\section{The Development Finance Corporation}

The work of an independent commission of inquiry to investigate the Development Finance Corporation is ongoing. Government has supported the work of the Commission of Inquiry into the DFC and has pledged to receive and act on the report of the Commission, including the forensic audit, as soon as it is submitted.

Recognizing the role of the Development Finance Corporation (DFC) in rapid accumulation of external debt, the authorities have begun an orderly liquidation of the institution. Over the past two years, the assets and liabilities of the DFC have been reduced from over US $\$ 300$ million to approximately US\$100 million at the end of July 2006. This has been accomplished through a process of asset revaluation, sale of properties, offsetting amounts owed between the Government and the DFC and return of non-income earning assets to the Government. The balance sheet, therefore, now represents a more accurate picture of the value of the DFC than previously. In this process, the Government assumed responsibility for approximately US\$210 million in liabilities. Over the period, the Government also received from the DFC significant real estate and other assets.

\section{Management of Petroleum Revenues}

Following the recent discovery of oil in commercial quantities in western Belize, the Government has sought to review and modernize the structure of Belize's earnings from the petroleum industry. This includes an amendment to the Income and Business Tax Act, which is presently before the National Assembly, to re-instate the income tax on petroleum operators at 40 percent of net income. Further work is being done at this time to determine mechanisms to achieve a greater degree of progressiveness in the taxes on petroleum operations.

As an urgent priority, the Government is working to establish a Petroleum Fund to bring full transparency to the process of accounting, investment and use of revenues earned by Belize from petroleum. This Petroleum Fund will also ensure that extraction of this non-renewable resource benefits future generations.

\section{Financial Sector Vulnerabilities}

Belize's banking system is generally sound and the staff's assessment in the Selected Issues paper indicates that it is relatively robust to various shocks. The authorities have implemented many of the recommendations of the 2003 Offshore Financial Center (OFC) assessment. They have tightened the standards for the loan-loss provisioning, as suggested by the staff and will implement the remaining recommendations of the OFC assessment, particularly in the area of insurance.

\section{Conclusion}

In summary, Belize continues to face a very difficult financing environment. The authorities are fully aware of the challenges they face. They recognize the need for careful management 
of these risks and are putting in place a comprehensive set of measures to address the problems. They look forward to the continued support of the international institutions and a successful conclusion of the debt negotiations so that they can chart the way ahead to a stable and sustainable future. 


\section{INTERNATIONAL MONETARY FUND}

EXTERNAL

Public Information Notice

RELATIONS

DEPARTMENT

Public Information Notice (PIN) No. 06/121

FOR IMMEDIATE RELEASE

October 20, 2006

International Monetary Fund

$70019^{\text {th }}$ Street, NW

Washington, D. C. 20431 USA

\section{IMF Executive Board Concludes 2006 Article IV Consultation with Belize}

On October 20, 2006, the Executive Board of the International Monetary Fund (IMF) concluded the Article IV consultation with Belize. ${ }^{1}$

\section{Background}

After a number of years of expansionary policies, stabilization measures were implemented more forcefully in the context of the 2005/06 budget (April to March). Partly in response to a tighter policy stance, economic growth slowed from 41/2 percent in 2004 to 31/2 percent in 2005, while inflation rose marginally to just over 4 percent, mainly reflecting higher fuel prices.

The overall fiscal deficit fell sharply from 8.6 percent of GDP in FY04/05 to 3.3 percent of GDP in FY05/06. During the same period, the primary balance shifted from a small deficit to a surplus of 3 percent of GDP. The fiscal correction reflected revenue measures taken in May 2005 , as well as lower interest payments and cuts in capital expenditure. The authorities also tightened liquidity by channeling social security deposits to the central bank and increasing the cash reserve and liquid asset requirements on three occasions by 1 percentage point each, including most recently in September 2006.

Reflecting in part the tightening of macroeconomic polices, the external current account deficit is expected to narrow considerably to $8 \frac{1}{2}$ percent of GDP in 2006 , from more than 14 percent of GDP in the 2005 . This recovery has been driven by a reduction in the trade balance, thanks

${ }^{1}$ Under Article IV of the IMF's Articles of Agreement, the IMF holds bilateral discussions with members, usually every year. A staff team visits the country, collects economic and financial information, and discusses with officials the country's economic developments and policies. On return to headquarters, the staff prepares a report, which forms the basis for discussion by the Executive Board. At the conclusion of the discussion, the Managing Director, as Chairman of the Board, summarizes the views of Executive Directors, and this summary is transmitted to the country's authorities. 
to an increase in traditional exports, the onset of crude oil exports, and restraint in import growth. Continued buoyant tourism earnings have also helped improve the external current account, as did a lower interest bill, because exceptional fees and charges that were incurred in 2004 and 2005 were not repeated in 2006.

Despite these welcome developments, the outlook for 2007 and beyond remains worrisome, as scheduled debt service obligations are high and will rise over time, weighing heavily on the overall balance of payments, particularly as access to voluntary market financing at affordable terms is impaired. The authorities have recognized the sustainability problem and in August 2006, they approached external commercial creditors to seek a cooperative agreement on restructuring public sector debt.

\section{Executive Board Assessment}

The Executive Directors welcomed the progress the authorities have made in addressing Belize's serious macroeconomic imbalances in the context of a home-grown adjustment strategy. A significant fiscal correction has been achieved in FY 2005/06 by increasing tax collection, reining in discretionary current spending, and reducing capital expenditure. In addition, tighter monetary conditions have helped slow credit growth and keep inflationary pressures in check. At the same time, Directors cautioned that large fiscal and balance of payments financing gaps are likely to persist in 2007 and beyond in the absence of fiscal and monetary policies to eliminate these gaps. To set the economy on a path to medium-term sustainability, the authorities should aim progressively and on a firm timetable to close the fiscal and balance of payments financing gaps, replenish international reserves, and reduce significantly the public debt burden. In that vein, Directors welcomed the authorities' strategy to reform the revenue system, strengthen public expenditure programming and debt management, and improve financial accountability and oversight.

Directors encouraged the authorities to persevere with disciplined macroeconomic policies in coming months in order to contain domestic demand and support an orderly debt restructuring. On the monetary side, the recent increase in bank reserve requirements is appropriate, and Directors noted that the authorities stand ready to take further action, if needed, to curb excess liquidity and contain private sector credit growth. On the fiscal side, Directors urged the authorities to work to achieve a primary surplus of $3 \frac{1}{2}$ percent of GDP in fiscal year 2006/07.

Directors agreed that achieving balance of payments sustainability in the medium term will require a greater fiscal effort, maintaining a prudent monetary stance, external financing, and debt service relief. They recommended raising the primary surplus by about 1 percentage point of GDP above that originally targeted, first by saving the bulk of projected revenues from oil production, and in later years by enhanced non-oil revenue collection and restrained current expenditures. They welcomed the authorities' intention to pursue these objectives.

Directors stressed the need for a set of carefully sequenced structural reforms to support fiscal and monetary discipline and foster stronger long-term growth, and were reassured by the authorities' commitment and ongoing efforts to move in this direction. In the fiscal area, the tax administration should be modernized, the tax base broadened, and oil and gasoline taxation 
reformed. Directors pointed to the importance of reviewing the pension system with the aim of limiting the growth of spending and making the system actuarially sound. Debt management practices should be improved. Directors supported the authorities' intention to improve governance of quasi-fiscal institutions, including winding up the operations of the Development Finance Corporation. In the monetary area, the central bank should work to broaden its market-based policy instruments in order to make monetary policy more effective. Also, the government's overdraft facility at the central bank should be eliminated to strengthen the bank's independence. Directors supported the authorities' request for Fund technical assistance to facilitate early actions in the areas of tax policy and monetary instruments.

Directors welcomed that Belize's banking system is generally sound and bank supervision has been strengthened. At the same time, they urged the authorities to consider implementing those recommendations of the IMF's 2003 Offshore Financial Center assessment that remain outstanding. In particular, there is a need to strengthen insurance supervision and broaden financial sector prudential regulations, especially with regard to loan-loss provisioning and loan collateral valuation.

Directors concurred with the authorities that the fixed exchange rate regime has anchored prices and expectations, and has generally served the economy well. Sustaining the peg will require that the authorities continue to work toward implementing macroeconomic policies that address Belize's economic and financial vulnerabilities. These considerations increase the importance of responding expeditiously to changes in the domestic and external environment and avoiding policy slippages.

Directors observed that reaching a cooperative agreement with private creditors on restructuring Belize's external debt will be critical for regaining balance of payments and debt sustainability. They welcomed the authorities' continuing engagement with multilateral and bilateral creditors as well, in order to promote an orderly adjustment process.

Directors welcomed Belize's participation in the Fund's General Data Dissemination System and encouraged the authorities to continue to strengthen the quality and timeliness of the country's economic statistics.

Public Information Notices (PINs) form part of the IMF's efforts to promote transparency of the IMF's views and analysis of economic developments and policies. With the consent of the country (or countries) concerned, PINs are issued after Executive Board discussions of Article IV consultations with member countries, of its surveillance of developments at the regional level, of post-program monitoring, and of ex post assessments of member countries with longer-term program engagements. PINs are also issued after Executive Board discussions of general policy matters, unless otherwise decided by the Executive Board in a particular case. The Staff Report of the 2006 Article IV Consultation with Belize is also available. 


\section{Belize: Selected Economic Indicators}

\begin{tabular}{|c|c|c|c|c|c|}
\hline & 2002 & 2003 & 2004 & $\begin{array}{l}\text { Prel. } \\
2005\end{array}$ & $\begin{array}{l}\text { Proj. } \\
2006\end{array}$ \\
\hline & \multicolumn{5}{|c|}{ (Annual percentage change, unless otherwise indicated) } \\
\hline \multicolumn{6}{|l|}{ National income and prices } \\
\hline GDP at constant prices & 5.1 & 9.3 & 4.6 & 3.5 & 5.3 \\
\hline Nominal GDP (in millions of Belize dollars) & $1,864.3$ & $1,975.2$ & $2,110.4$ & $2,221.8$ & $2,433.6$ \\
\hline Consumer prices (end of period) & 3.2 & 2.3 & 3.1 & 4.2 & 4.4 \\
\hline \multirow[t]{2}{*}{ Real effective exchange rate } & -0.4 & -2.5 & -2.4 & -1.3 & $\ldots$ \\
\hline & \multicolumn{5}{|c|}{ (In percent of GDP) } \\
\hline \multicolumn{6}{|l|}{ National accounts } \\
\hline Gross domestic investment $1 /$ & 22.3 & 21.5 & 18.9 & 23.1 & 18.0 \\
\hline Gross national saving & 2.0 & 3.3 & 4.6 & 8.8 & 9.2 \\
\hline \multicolumn{6}{|l|}{ Central government } \\
\hline Revenue and grants & 25.3 & 21.4 & 22.8 & 23.5 & 24.5 \\
\hline Expenditure and net lending $2 /$ & 30.9 & 32.0 & 29.2 & 29.0 & 27.8 \\
\hline Overall balance & -5.6 & -10.6 & -6.4 & -5.5 & -3.3 \\
\hline \multirow[t]{2}{*}{ Primary balance } & -2.4 & -5.9 & 0.8 & 2.0 & 3.2 \\
\hline & \multicolumn{5}{|c|}{ (Annual percentage change, unless otherwise indicated) } \\
\hline \multicolumn{6}{|l|}{ Money and credit } \\
\hline Credit to the private sector $1 /$ & 19.2 & 13.2 & 9.6 & 11.3 & 5.5 \\
\hline Money and quasi-money (M2) & 2.1 & 4.7 & 7.5 & 5.9 & 9.5 \\
\hline & \multicolumn{5}{|c|}{ (In percent of GDP, unless otherwise indicated) } \\
\hline \multicolumn{6}{|l|}{ External Sector } \\
\hline External current account & -20.3 & -18.2 & -14.4 & -14.3 & -8.8 \\
\hline Overall balance of payments & 0.2 & -3.0 & -3.0 & 1.6 & -0.8 \\
\hline Public and publicly guaranteed debt $3 /$ & 89.0 & 102.3 & 100.2 & 98.5 & 92.9 \\
\hline Domestic & 3.2 & 5.7 & 9.0 & 7.3 & 9.8 \\
\hline External & 85.8 & 96.7 & 91.2 & 91.2 & 83.1 \\
\hline Gross official reserves (in months of imports) $3 /$ & 2.0 & 1.4 & 0.8 & 1.0 & 0.7 \\
\hline
\end{tabular}

Sources: Belize authorities; and IMF staff estimates and projections.

1/ Including inventories and discrepancy.

2/ Including unidentified expenditures.

3/ End of period. 